\title{
Retracted: Climatic, Regional Land-Use Intensity, Landscape, and Local Variables Predicting Best the Occurrence and Distribution of Bee Community Diversity in Various Farmland Habitats in Uganda
}

\author{
Psyche \\ Received 23 December 2013; Accepted 23 December 2013; Published 28 January 2014 \\ Copyright (C) 2014 Psyche. This is an open access article distributed under the Creative Commons Attribution License, which \\ permits unrestricted use, distribution, and reproduction in any medium, provided the original work is properly cited.
}

\begin{abstract}
The article titled "Climatic, Regional Land-Use Intensity, Landscape, and Local Variables Predicting Best the Occurrence and Distribution of Bee Community Diversity in Various Farmland Habitats in Uganda" [1], published in Psyche, has been retracted as it was found to include erroneous data. Its findings and conclusion cannot be relied on.
\end{abstract}

\section{References}

[1] T. Munyuli, "Climatic, regional land-use intensity, landscape, and local variables predicting best the occurrence and distribution of bee community diversity in various farmland habitats in Uganda," Psyche, vol. 2013, Article ID 564528, 38 pages, 2013. 

of Bee Community Diversity in Various Farmland Habitats in Uganda

\section{B. Théodore Munyuli ${ }^{1,2,3,4}$}

${ }^{1}$ Academic Affairs and Research Program, Cinquantenaire University (UNI-50/Lwiro), D.S. Bukavu, South-Kivu Province, Democratic Republic of Congo

${ }^{2}$ Department of Biological, Agricultural and Environment Sciences, National Center for Research in Natural Sciences (CRSN/Lwiro), D.S. Bukavu, South-Kivu Province, Democratic Republic of Congo

${ }^{3}$ Centre of research for health promotion (CRPS), Department of Nutrition and Dietetics, Bukavu Higher Institute of Medical Techniques (ISTM/Bukavu), P.O. Box 3036, Bukavu, South-Kivu Province, Democratic Republic of Congo

${ }^{4}$ Department of Environmental and Natural Resource Economics, Faculty of Natural Resources and Environmental Sciences, Namasagali Campus, Busitema University, P.O. Box 236, Tororo, Uganda

Correspondence should be addressed to M. B. Théodore Munyuli; tmunyuli@gmail.com tmunyuli@yahoo.com

Received 8 September 2012; Revised 14 December 2012; Accepted 17 December 2012

Academic Editor: Fernando B. Noll

Copyright ( 2013 M. B. Théodore Munyuli. This is an open access article distributed under the Creative Commons Attribution License, which permits unrestricted use, distribution, and reproduction in any medium, provided the original work is properly cited.

This study was conducted in 2006 in central Uganda to provide baseline data on relationships between bee community variables and local, climatic, landscape and regional drivers affecting bee community abundance and diversity in agricultural landscapes. Bee abundance and species richness increased significantly $(P<0.05)$ with increase in percent cover of semi-natural habitats and the abundance of wild and cultivated floral resources in the landscape. There were strong linear declines $(P<0.001)$ in bee species richness and abundance with cultivation intensity. Bee species richness declined very steeply with forest distance. Bee species richness and abundance were negatively affected by land-use intensity $(P<0.01)$. Bee species richness and abundance were strongly negatively correlated $(P<0.001)$ with increase in mean annual temperatures in the previous years than in current years indicating potential vulnerability of local bee species to future climate changes. The percent cover of semi-natural habitats and natural in the farmland predicted best the occurrence and distribution in central Uganda. It is therefore recommended to policy-makers and to farmers to invest in the protection of forest fragments (and related semi-natural habitats) acting as buffer in the mitigation of negative effects of climate change on bee biodiversity and pollination services delivery.

\section{Introduction}

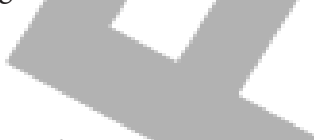

Pollinators provide a crucial ecosystem service through their role in the sexual reproduction of both wild plants and crops [1-3]. Pioneering works highlighted the fact that wild bees are by far the most important providers of vital pollination services in the world [4-7]. Their ongoing decline and potential ecological and economic consequences are therefore of major concern [8-11]. Long-term losses of certain pollinator species may threaten future ability of rural landscapes to maintain current levels of crop production.

There exist multitude factors (pressures), but currently suspected drivers (working alone or in synergy to produce negative or positive impacts) with potential effects (e.g., likely causing decline) in bees include land use change, use of pesticides (pesticide exposure) and reductions in population genetic diversity, farming and farm management practices changes, habitat loss and fragmentation, introduction of non 
native invasive species, species competition for resources, parasites and pathogen spread, heavy metal pollution, and climate change $[9,11-13]$. Interactions between these multiple factors and various other factors are likely; for example, nutritional stress, due to a lack of floral resources or their poor quality, may lower the tolerance of pollinators to pesticides and diseases [14].

With an estimated 20,000-30,000 species worldwide [15, $16]$, bees are a useful group for the study of biodiversity and ecosystem services delivery in farmland habitats [17-21]. Bees are therefore important bioindicators of ecosystem health $[19,22-24]$ and environmental quality in different land-uses and ecosystems [24] since they reflect ecological changes by their richness and related parameters [25] and are sensitive to environmental alterations.

Animal pollinators contribute to approximately one-third of global food production [1], and pollination by bees and other insects is responsible for as much as $70 \%-84 \%$ of the 264 crop species grown in the world. Globally, the economics gains from crop pollination by free ecological services provided by wild bees, honeybees, and other insect pollinators are high and have been estimated to be worth several billions US dollars per year $[2,6]$. The value of pollination to agricultural production worldwide is currently estimated to be worth US $\$ 226$ billion ( $€ 153$ billion) per year or approximately $39 \%$ of the world crop production value ( $€ 625$ billion) from the total value of 46 insect pollinated direct crop species [25, 26]. Although one-third of the world's food production relies on animals for pollination, it is, however, projected that insect pollinators (bees) may be responsible of more than one-third US\$1 trillion in annual sales of agricultural products worldwide [27-30]. Challenges related to the conservation of bee faunas in tropical agricultural landscapes include the absence of basic knowledge about their biology, natural history, vulnerability to climate change and spatio-temporal distribution of communities (abundance, richness, diversity) in agricultural landscapes. In addition, factors driving the distribution of different bee species in different localities in farmlands of Uganda are not documented.

There exist several land-use pressures and land degradation problems in central Uganda; and agroforestry systems were developed and disseminated in rural areas of central Uganda as a way of maximizing yields on small scale farms [30]. In the coffee-banana agroforestry system of central Uganda, small-scale farmers grow and rely (for their livelihoods) on several foods (e.g., banana) and food crops (e.g., coffee) that highly require animal pollination to set fruit/seeds [27]. Due to negative effects of various drivers, decline in solitary and social wild bees (that are important pollinators of wild plant species and many insect-pollinated crops) has been predicted worldwide. Decline in pollinator availability may be caused to a greater extent by variation in the abundance of generalist rather than specialist bee pollinators $[31,32]$. Decline in growth rates of bees may be likely affected by both abiotic factors and biotic factors.

Although pollination is a critical ecosystem service and that bees are the most important pollinators, they are endangered by intensive agricultural practices. Knowledge, on the relationships between insect pollinators and landscape structure/composition, land use change and habitat quality in Uganda, is still limited. While landscape context and habitat quality are known to influence species richness and abundance of bees [17], there is lack of information of the influences of climate factors on bee species richness and abundance. Climate change and variability may be contributing in boosting declining bee populations including afrotropical bees. Worldwide, empirical studies that take climatic variables into account are rare. However, there exist scantly speculative literature on potential effects climate change on plant-pollinator interactions and the consequence for pollination services delivery [33]. No previous studies have examined experimentally the combined (simultaneous) effects of micro, local, landscape, land-use intensity and regional and climatic factors on abundance and species richness bees in agricultural landscapes in Uganda and in Sub-Saharan Africa. However such studies are important to help in developing strategies to prevent future decline in bee species and guaranteeing future stability of pollinatordependent crop yields and for food security of human communities depending on these crops. It is still not clear how in the future local, landscape and climatic factors will simultaneously affect the pattern of bee species richness and abundance in agricultural landscapes in Uganda.

Climate warming may interact to disrupt this crucial mutualism by altering plant chemistry in ways that alter floral attractiveness or even nutritional rewards for bees [33]. One possible effect of climate change is the generation of a mismatch in the seasonal timing of interacting organisms, owing to species-specific shifts in phenology. Local environmental conditions are the primary determinants of emergence phenology in bees and their food plants. In other words, phenology of plants and bees is regulated in similar ways by temperature, but that plants are more likely than bees to advance phenology in response to springtime warming. Different responses of bees towards climate change may lead to an increasing asynchrony in the life cycles of bees and flowering plants [29]. With the predicted climate change in interaction with land-use change and habitat alteration, bee species richness and abundance are expected to change patterns in occurrence with the resultant negative effect on pollination services delivery. Understanding how landscape characteristics (composition, structure, and configuration) affect bee biodiversity patterns and ecological processes at local and landscape scales will be critical for mitigating future negative effects of global environmental change [33] on bee biodiversity.

Climate change is only starting to shape the pollination service research agenda. The complexity of the impact of this phenomenon on bee biodiversity and pollination services delivery remains largely unveiled particularly in Sub-Saharan Africa. Future climate change is expected to have different scenarios (rate of shifts in distribution range, or rate of extirpation, rate of decline or disappearance in the landscape) upon bees. Responses of different species to change in climatic conditions are predicted to range from thriving (i.e., species capable of living under the new set of conditions) to adapting (i.e., species capable of surviving a change in global 
conditions by changing their ecology, physiology, and/or distribution) and going extinct.

Responses of different bee species to climate change are not experimentally documented in Uganda and in East Africa. It may be important to identify how different bee species will adapt to future climatic change as well predicting how bee species will disappear. However, global environmental changes (driven by multiple interacting drivers/pressures) are expected to have manifold effects (and unanticipated outcomes) on bee species richness and populations and on pollination services [28]. Global warming or climate change (changes in temperature and rainfall) is likely to have significant impacts on bee species richness and populations across different locations in eastern and central Africa. Specialized species may be vulnerable and reach high levels of risk of extinction in the landscapes.

Likely impacts of climate change on bee species richness may be linked to life history traits of different bee species (phenology, sociality, and bee-host plant synchronization). Trait-based approaches to predict and analyze the effects of climate change in interaction with other local and landscape drivers have been suggested by scientists. Responses of bees may vary among taxa. Life-history traits are related to the specialization of the bee species (nesting guide and feeding habit) and to sensitivity lower/higher risk of harm from various threats.

Changing flowering phenologies under climate change is well documented in temperature regions. The impact of climate change on plant-pollinator mutualisms is little understood or well predicted in Africa. Despite the enormous economic and ecological importance of bees as pollinators, currently there are no studies investigating the interaction between bee species and abundance and historical/current climatic factors (rainfall and temperature) in Uganda and in eastern and central Africa. However, such studies are also important to monitor and prevent decline in species richness and in pollination services delivery. Now that climate change is a reality in Africa, there is an urgent need to investigate its potential impact on bee species richness and abundance to foster to speculation on potential consequences of climate change on bee richness and pollination service delivery for food security and livelihoods of people.

Overall, there is a need to know the degree at which different environmental factors may affect bee communities to better plan conservation strategies of these pollinating service agents and prevent their decline in face of future climate changes, thus guaranteeing yield stability of pollinatordependent crops while improving small-scale farmers' food security and livelihoods. Speculating on bee species vulnerability to future changes in environmental conditions in which they are found, and modeling (predicting/forecasting) future changes in species populations may be an approach to inform conservation policy.

Factors influencing patterns of occurrence $[30,34]$ of bee communities in relationship to climate factors have not yet been studied in Uganda. Understanding how land-use intensity, climatic, landscape and local level-factors influence the presence/absence of different bee faunal species in different localities of an agricultural landscape can be very useful in influencing rural development policies about defining strategies to prevent future decline in face global environmental change threat.

Current bee abundance and richness may be the result of the simultaneous cumulative effects of local, landscape composition and regional/climatic factors over the recent years. Thus accounting for the recent of weather variability may be relevant in predicting future response of bee communities to climatic changes.

The general objective of this study was therefore to determine the relationships between bee community variables (abundance, species richness) and climatic, regional, landscape and local variables. The overall goal was to determine the degree to which these different variables can powerfully predict future patterns of bee communities in farmlands of central Uganda. It was hypothesized that bee abundance and species richness on agricultural landscapes in central Uganda are related to local and landscape variables, but not to regional climatic variables. The sub-hypothesis tested also whether precipitations/temperatures (climatic factors) in the current and previous year were associated with current bee abundance and richness, since precipitation is a primary driver of plant population dynamics and of bee emergence dynamics in most agricultural and natural regions $[17,18]$.

\section{Material and Methods}

2.1. Study Area. This study was conducted in the bananacoffee system of Lake Victoria Arc covering several districts of central Uganda (Figure 1). The study zone (average latitude: $0.5^{\circ} 31^{\prime} 22^{\prime \prime}$; longitude: $31^{\circ} 11^{\prime} 71^{\prime \prime}$; altitude: $1080-1325 \mathrm{~m}$ ) is characterized by ferrisoils with high to medium fertility level and receives on average $1000-1800 \mathrm{~mm}$ of rainfall per annum on a bimodal pattern (rainy seasons: March-May, SeptemberNovember; semi-dry to dry seasons: June-August, DecemberFebruary) with $28.7 \pm 2.77^{\circ} \mathrm{C}$ and $68.65 \pm 8.91 \%$ of mean annual temperature and relative humidity respectively [29, 35]. But the rainfall amounts and patterns are unpredictable. The study zone belong to the Lake Victoria phytochorion [19-21] with shrubs of Acacia spp., legume trees, melliferous plant species, Papyrus and palms ranging from 2 to $15 \mathrm{~m}$ high dominating the remnant secondary vegetation [28]. In this study region, coffee (Coffea canephora Pierre ex Froehner) is the main cash crop and banana the main staple food crop. Several pollinator-dependent food and cash crops are grown in small-scale monoculture and/or polyculture fields that are integrated into this coffee-banana agroforestry system including home-gardens. There were no standard crops per study sites but most crops were found grown in almost all study sites. Crops grown as sole or in association with coffee and or banana include cassava (Manihot esculentum L.), sweet-potato, (Ipomoea batatus L.), maize (Zea mays L.), beans (Phaseolus vulgaris L.), groundnut (Arachis hypogea L.), tomato (Lycopersicon esculentum L.), watermelon (Citrullus lanatus L.), pumpkin (Cucurbita moschata L.), cucumber (Cucumis sativus L.), melon (Cucumis melo L.), chilies (Capsicum spp.); and several other fruits, vegetables and horticultural crops (cabbage, onion, etc., egg plants, 
sim-sim, etc.). The majority of these crops are grown in small-scale monoculture and or polyculture fields that are integrated into the coffee-banana agroforest production systems. The agroforestry system is also dominated by several native/indigenous, fruit and agroforestry tree species [27$30,35]$.

Rural central Uganda is mosaic landscape where "islands" of patches of natural habitats (forest fragments, forest reserves, wetlands, woodlands) and linear (e.g., hedgerows) and non-linear (fallow fields, grasslands, woodlots, cattle pastures or rangelands) features of semi-natural habitats [27, 28] that serve as "field boundaries" of the variety of smallscale fields; are found scattered within agricultural matrices. Compared to other regions (districts) of the country, the study area (central Uganda) is also characterized by high demographic pressure, limited access to arable lands, continuous cultivation and over-exploited lands under unrevised land policies [18].

2.2. Study Sites. In this study region, data was collected in 26 different study sites $\left(1 \mathrm{~km}^{2}\right.$ size each) with different environmental characteristics (Figure 1). The 26 study sites were chosen distant one from another to reduce on confounding factors. Prior to the selection of different study sites, a study tour of different sites was made, and sites characteristics were noted. Thus, the 26 study sites were selected along contrasting environmental gradients, farm management systems, agroecological, semi-natural habitats, vegetation characteristics, and land-use intensity gradients. The study was designed to minimize spatial autocorrelation between local and landscape-scale variables measured within study sites by maintaining a minimum distance between study sites and clusters (each cluster was composed of 2 or 4 sites located in the same zone with similar general vegetation and environmental characteristics). The minimum distance between two study sites selected within a cluster was of $2-25 \mathrm{~km}$ (which is beyond the normal foraging range of most pollinator species), and the minimum distance between clusters was of $50-250 \mathrm{~km}$. All 26 agricultural field sites had also some forest remnant tree species retained within them, ranging from 1 to 175 trees/ha found both in crop fields as well inside remnant natural vegetations scattered inside the forest. The distance between a study site and the nearest forest fragment/wetland varied from 2 to $>2000 \mathrm{~m}$ and the size of the forest fragments found in the vicinity of crop fields varied from very small fragments of 0.1 ha to large forests greater than 850 ha in size. Shade cover within the coffeebanana agroforests ranged from $10 \%$ to $92 \%$, and shade tree density was of more than 5-500 trees (all species combined) per hectare, excluding the density of other agroforestry and fruit tree species. Overall, the species richness of typical coffee shade trees, agroforestry trees, forest remnant trees, and fruit trees varied from 1.23 to 15.45 species per hectare.

There exist in this study region some large monoculture plantations (sugar cane plantations, coffee plantations, tea plantations, etc.). However, compared to large scale plantations, study sites that were covered by typical banana-coffee agroforests mixed with semi-natural habitats (e.g., young fallows) and related small-scale farms were of $95 \%$, whereas study sites located within or in the proximity of large scale plantations covered approximately $5 \%$ of the farm-landscape studied. Most study sites were less similar in terms of altitude (altitude: 1080-1325 m) and in terms of type of semi-natural habitats surrounding all $1 \mathrm{~km}^{2}$ study sites selected. However, few study sites (16 sites) had in their immediate vicinity natural forests and/or large wetlands.

2.3. Sampling Design and Bee Sampling Methods. Bees were sampled in each of the 26 study sites. Each study site was divided into five linear transects of $1000 \times 200 \mathrm{~m}$ each. Transects were used as basic units for bee sampling. They were also used as basic units for measuring all land-uses, habitats, and vegetation data. In each round of data collection, one transect per site was used. Thus, bees were sampled on one central transect $(200 \mathrm{~m}$ wide $\times 1000 \mathrm{~m}$ long) per study site. A sampling belt ( $20 \mathrm{~m}$ wide $\times 1000 \mathrm{~m}$ long) was selected in the middle of each central transect as recommended [17, $18,30]$ to reduce bias in bee sampling. Using a tape measure, the sampling belt of each selected central transect was divided into 10 sections (sampling plots) of the same size ( $20 \mathrm{~m}$ wide $\times 100 \mathrm{~m}$ long each). The 10 sampling plots of each sampling belt were visited at each sampling date.

Bee sampling with each of the three sampling methods was concentrated in the sampling belt. Bees were sampled using three complementary sampling methods: handnetting, transect walk-and-counts, and pan-trapping. Multiple trapping methods are recommended to be used to catch a wide array of bees as each sampling method has their own biases [17].

Transects walks-and-counts (standardized transect walks) method was used to sample foraging bees in the sampling belt by two observers per site as recommended $[29,30,36]$. Transects walks-and-counts are one of the standard protocols for visual observations and presence recording of bees in the fields. Observations of foraging activities and bee counts were done on flowering patches found within different habitats and land-uses while walking along transects at a slow speed $(<0.25 \mathrm{~km}$ per hour). Observations were made under conditions favorable for bee flights: sunny or cool weather and weak wind. Hand-netting ("sweep-net" sampling) of bees with a hand-net $(30 \mathrm{~cm}$ diameter) was conducted in patches of fresh flowers in each plot immediately after visual censuses. Transects were sampled from $08 \mathrm{~h} 00$ to $17 \mathrm{~h} 00$ local time to capture bees on wild blooming plants as recommended [11, 17, 19, 34, 37, 38]. Only hand-net bee samples were transferred to zip lock plastic bags and placed in a portable cooler.

Pan traps have been used to sample (bees and other insects) for almost 2 decades $[9,11,17]$. In the pan-trapping method, a single trapping point was established within each plot. Pan traps were constructed from $236.5 \mathrm{~mL}$ white, blue and yellow plastic bowls $[1,9,10,39,40]$. The bowls (brand "Solo" supplied by Prof Simon Potts from the University of Reading, UK) were sprayed with ultra-violet bright paint colors (blue, yellow and white). Pantraps were filled with water and a small amount of detergent to reduce surface 


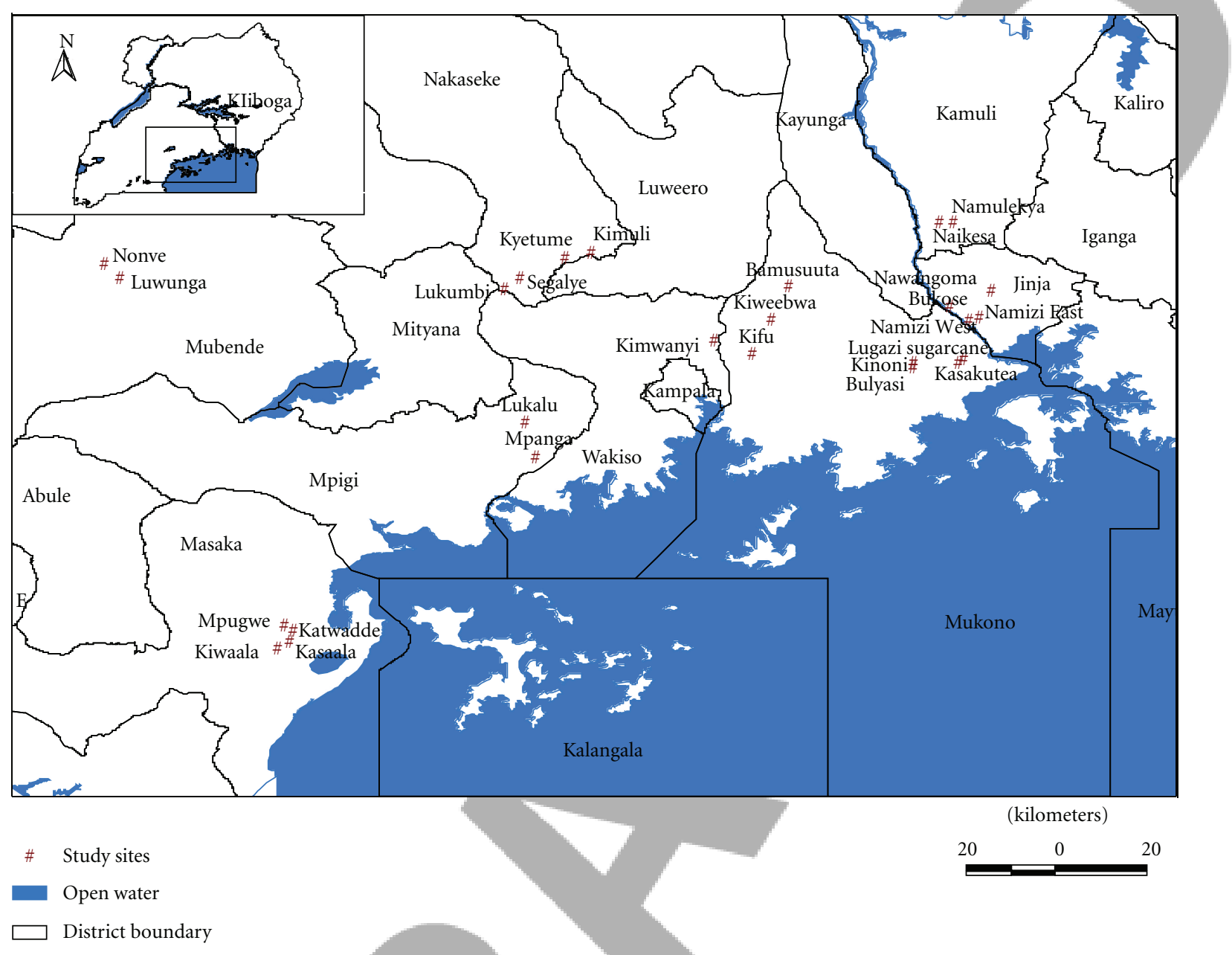

FIGURE 1: Location of study sites in which bee fauna survey was conducted in the banana-coffee growing area around Lake Victoria in Uganda in 2006 .

tension to help insect sink and increase UV-light reflection $[28,29]$, thereby attracting bees and other insects, which fly into the water and drown.

At each sampling point, three pan traps (blue, yellow and white) were spaced $5 \mathrm{~m}$ apart on the ground as recommended [35]. Pan traps were placed elevated in the plant canopy at the height of flowers easily visible by flying insects. Bowls were hung on plant branches or on stakes fixed in the soil. In each pan trap, unscented, biodegradable liquid detergent was poured into pan traps $(2.5 \mathrm{~mL}$ detergent/liter water). Pan-traps were left in place for about two days before collecting samples to reduce bias in the sampling procedure $[11,40]$. Most pans used were generally placed far from tracks to reduce disturbance by curious un-informed villagers or school children. A limited number of traps were found disturbed (i.e., empty pan traps, pan-traps taken away, etc.) during the second and the fourth rounds of data collection, resulting in a few missing data points. During the rainy seasons, holes were added in the upper zone of each pantrap to allow excess water to drain without washing away bee samples.
For each of the three sampling methods, transect walkand counts, hand-netting, and pan-trapping $[10,18]$, bees were sampled during five consecutive rounds from January 2006 to December 2006 (Round 1: January-April, Round 2: May-June, Round 3: July-August, Round 4: SeptemberOctober and Round 5: November-December). Sampling was conducted consistently across crop growing seasons in order to compare sample yields (bee species richness and individuals estimates) and between rainy (wet) and dry seasons. Bee fauna surveys were conducted across months of highest (September-May) and lowest (July-August) bee abundance and species richness [17]. Each round of data collection lasted 5 to 7 weeks. Across sampling methods, bees were sampled for 30-min period per sampling plot between $8 \mathrm{~h} 00$ $17 \mathrm{~h} 00$. Although being are that some bees start foraging [22, 30] even before sunrise and stop soon afterwards (example: crepuscular bee species representing less than $0.1 \%$ of bee species found in central Uganda and that may be lost during bee sampling), bees were sampled between $8 \mathrm{~h} 00$ and 17 h00 due to time constraint and depending on local light conditions and ambient temperature. Bee specimens from 
each sampling method (hand-nets, pan-traps) were strained into plastic vials containing alcohol (70\% ethanol) and taken to the laboratory for identification to the highest possible taxonomic level. Bee samples were sorted out at Makerere University (Zoology department museums). The majority (95\% of bee samples) were identified up to species levels at bio-systematic division of the plant protection research institute (Pretoria- South Africa). Other minor identifications were conducted at Natural History Museums-London (UK), Smithsonian Tropical Research Institute-Panama, and University of Reading (UK). The established reference collection of bees from central Uganda is deposited at Makerere University Zoology Museum.

Surveys on bee food plants and bee nest trees were conducted parallel to bee faunistic surveys. Data on different types and size of semi-natural habitats/land-uses was also collected parallel to bee surveys. During bee surveys, the number of nests and nesting sites for most bee species were counted in these different habitats/land-use types. Bee food plants and Bee nest were identified in the field with author experience. However, when in doubt, bee food plant specimens were collected and identifications to species-level were confirmed at Makerere University Herbarium.

2.4. Measurement of Correlative (Factors) Variables. In this study, different metrics (local, landscape, regional factors) affecting pollinator populations and species richness in farmlandscapes of central Uganda were measured. In this study, local variables (farm-level variables) referred to factors affecting bee communities at a local scale (1-500 m radius). Local factors are limited at an individual plot/land-use level [30]. Landscape-scale factors were referred to factors operating at a large scale level ( $>0.5-1 \mathrm{~km}$ radius) covering flight range of various typical farmland native bee species [29]. Regional variables referred to broad scaled factors that may have an indirect effect on bee activities at local level from very far. These are factors operating at a larger scale level $(>1-$ $100 \mathrm{~km}$ radius). Thus, few local, landscape, regional and climatic factors of importance for bees were measured at different scale levels.

Local and landscape variables were measured following approaches by previous workers [41-45]. Measured local variables included the amount of floral resources [29]. These included the percent cover of wild flowering plants (trees, shrubs and herbs) or the mass flowering of wild plants, the number of wild blooming plant species, and the percent cover of cultivated floral resources (percent of cultivated pollinatordependent and non-pollinator dependent crops) per $1 \mathrm{~km}^{2}$ area (site). Data on herbs were collected from ten quadrats measuring $5 \mathrm{~m} \times 5 \mathrm{~m}\left(25 \mathrm{~m}^{2}\right)$ while those on shrub and trees were collected for in twenty quadrats measuring $10 \mathrm{~m} \times 50 \mathrm{~m}$ $\left(500 \mathrm{~m}^{2}\right)$. All trees with stems greater than $10 \mathrm{~cm}$ diameter at breast height $(\mathrm{dbh})$ were recorded. Data on the number of fresh flowers were also recorded in "plots" of $5 \times 5 \mathrm{~m}$ $\left(25 \mathrm{~m}^{2}\right)$ dimension [46]. The quadrats (plots) were randomly established in each study site as recommended $[22,23]$ to determine the number of plant species. Measurement of wild floral resources focused only on plant in bloom. Wild blooming floral resources were measured in five samples (five rounds) as the bee data.

The percentage cover (area covered in hectares) of cultivated floral resources was determined based on land-use data collected about the proportion cover of each type of crops cultivated [1] in a $1 \mathrm{~km}^{2}$ site area. Later, all cultivated crops were grouped in two subcategories $[17,18,29]$ and their respective proportion determined based on area (ha) covered by (i) pollinator-dependent crops and (ii) by non-pollinatordependent crops. Therefore, crops were categorized into two subgroups based on the dependence ratios used by Klein et al. [1].

Landscape-level land-use data were collected within a $1 \mathrm{~km}^{2}$ site. Each square kilometre was delineated using a global positioning system (GPS). Because there were no previously published data on small-scale land-use patterns in the study region, to facilitate basic measurements about different land uses, the $\mathrm{km}^{2}$ area was divided into five transects of $200 \mathrm{~m} \times 1000 \mathrm{~m}[18,28]$. Here, the areas with different landuse types were measured using GPS or a tape in case of small fields (50 $\mathrm{m} \times 50 \mathrm{~m}$ and less). Land-use types were grouped into major land-use types based on their size (0.06 ha- 1 ha to $9.95-16.45 \mathrm{ha}$ ) and frequency of occurrence in order to calculate the area covered by semi-natural habitats, the area covered by crops and the cover of dependent and nondependent cultivated crops per $\mathrm{km}^{2}$ area $[22,27,30,35]$. The term semi-natural habitats included all linear (hedgerows, field margins, roadsides, track-sides, stream edges, etc.) and nonlinear (fallow fields, grasslands, woodlands, woodlots, etc.) semi-natural habitats [47-49] of ecological importance for pollinators living in farm-landscapes $[27,28,35]$. These seminatural habitats play an important role in the maintenance of many bee species in rural landscapes in Uganda [27, 29]. Semi-natural habitats have been shown to be important in structuring bee communities in agricultural landscapes [22]. Young fallow fields play a particular role as foraging habitats and bee refugia and as reservoir of other ecosystem services delivery agents in rural landscapes [22, 23, 27-30, 35]. Pollinator-dependent crops are those that require a visit to its flowers by a pollinator to set fruits/seeds $[1,29]$.

Three landscape variables of ecological importance [50] for bee biodiversity and pollination studies [29] in agricultural matrices were then calculated for each $1 \mathrm{~km}^{2}$ study site: (i) the percent of semi-natural habitats; (ii) the cultivation intensity, that is, the percentage of the total land area cropped; (iii) the distance from a given study site to the nearest potential natural pollinators' source (forest and wetlands) the distance from a large (defined) forest fragment/natural wetland $[22,30]$. Distances up to $100 \mathrm{~m}$ were measured with a tape, otherwise with GPS (corrected to $\pm 1 \mathrm{~m}$ accuracy with Pathfinder v 2.0).

Regional land-use categories (gradients) were obtained from the Makerere University Geographic Information Services $[23,28]$. Broad land uses classified as low-intensity use include areas where at least three-quarters of the land is uncultivated. Medium are managed habitat types where there is an almost equal distribution of cultivated and uncultivated land. High are areas dominated by crops or livestock (such 
as only one-quarter of the total land is used for other purposes rather crops and livestock). Very high represents large monoculture estates of tea, sugar, coffee, and so on $[22,23,27-30]$.

Preliminary analysis of relationships between butterfly community variables (species richness and abundance) and weather/climatic factors (rainfalls, temperature, etc.) in previous years (10 years, 2 years before) and current years revealed potential influences of climate change on the distribution, occurrence, and activities of different butterfly species $[17,18]$. Thus, this study aimed at verifying if this trend was the same for all farmland bee species. Therefore, data on regional climatic factors were obtained from meteorological stations located in the study area including Kamenyamigo meteorological station covering Masaka cluster (sites: Kasaala, Katwadde, Kiwaala, and Mpugwe) in Masaka district; Entebbe meteorological station covering Kalagi (sites: Bamusuuta, Kifu, Kimwanyi, and Kiweebwa), Lugazi (sites: Kasaku and Sugar), Mpigi (sites: Lukalu and Mpanga) and Mabira (sites: Bulyasi and Kinoni) clusters in Mukono district; Jinja meteorological station covering Kamuli (sites: Naikesa and Namulekya), and Bujjagali (sites: Bukose, Namizi-East, Namizi West, and Nawangoma) clusters in Kamuli district and Kiige meteorological stations covering Nakaseke (sites: Kimuli, Kyetume, Lukumbi, and Segalye) and Kaweri coffee plantation (sites: Nomve and Luwunga) clusters in Mubende district. From the raw data obtained from the different meteorological stations, a monthly mean for 10 years (1998 to 2007) of temperatures and rainfalls was calculated to see the trends in the rainfall patterns and temperature since such oscillations can affect the patterns of pollinator communities in rural landscapes. Other variables (helping in detecting current patterns of bees in relationship to past climatic events) calculated included (i) the overall mean rains (means/month/10 years); (ii) the overall daily mean minimum temperature (mean of 10 years); (iii) the overall daily mean maximum temperature (mean 10 years); (iv) the mean monthly rainfalls (2007); (v) the mean monthly maximum temperature (2005); the mean monthly maximum temperature (2006); (vi) the mean monthly maximum temperature (2007); (vii) the mean monthly minimum temperature (2005); (iix) the mean monthly minimum temperature (2006); (ix) the mean monthly minimum temperature (2007); (x) the mean monthly rainfalls (2005) and (xi) the mean monthly rainfalls (2006).

2.5. Data Analysis. Although collections were not similar, data from the three sources (transect walk-and-counts, pantraps, and hand-nets) were pooled as recommended [18, 36] to provide total bee abundance and species richness estimates per transect/study site/sampling round. In fact, bee abundances $\left(\chi^{2} 2 \mathrm{df}=26.78, P<0.001\right)$ and species richness $\left(\chi^{2} 2 \mathrm{df}=12.56, P<0.01\right)$ were significantly different among the three sampling methods, but pooling data from the three different sampling methods was still conducted and motivated by the fact the interests was estimates of overall abundance and specie richness and not on comparing the efficiency of the three different sampling methods. In addition, each of three sampling methods applied can be associated with bias towards number of species and individuals detectable by the sampling method [18].

Genera-tribe richness, species richness, abundance and dominance were calculated to highlight (indicate) the structure/characteristic of bee communities studied; they were expected to be driven by various local, landscape, regional and climatic factors. Thus, species richness of some taxa (e.g., genera, tribe) was calculated as the number of species belonging to that taxa.

Bee abundance was calculated as the total number of individuals recorded per transect each sampling day. The species richness was calculated as the total numbers of bee species recorded per transect per study site each sampling day. Species dominance $(D)$ was calculated according to Munyuli [18] and Magurran [51]: $D=$ (abundance of a species/total abundances recorded) $\times 100$. If $D>5 \%$, the species was termed a dominant species. Species accumulation and estimation curves were constructed/generated using the Jacknife-1 estimator [51, 52].

To determine "indicator species" or "characteristic species" of pollinator communities from farmland habitats of central Uganda, indicator (IndVal) method of Dufrêne and Legendre was adopted and used in this study in a modified form as recommended by Munyuli [22] to identify indicator. Indicator species are ecological "characteristic species" or ubiquitous/common species of bee communities inhabiting certain type of habitats of a given landscape [22]. Indicator species are potentially effective pollinator species delivering pollination services to wild and cultivated crops in the landscape $[18,30]$. Knowledge of indicator species is important to acquire since it gives an idea on reliable spatio-temporal pollination services delivery agent species in the rural landscapes. Such knowledge may help in predicting/speculating on responses of different bee species to various drivers.

The correlation of independents variables (e.g., meteorological variables, local and landscape variables) characterizing the 26 study sites with dependent variables (bee species richness, bee abundance) were tested using Pearson correlation. The derived correlation coefficients and $P$ values associated with the paired variables were presented in matrix of correlation. Correlation analysis was used to determine the suite of variables most closely related to bee species richness and abundances measured. The different independents variables were checked to prevent collinearity following approaches previously described by Munyuli [30]. Based on the correlation matrix of all variables measured, only independents variables that were significantly $(P<$ $0.05)$ related to dependent variables (bee communities) were chosen for further analyses in simple regression analyses. These illustrated the trends and magnitude of the effects of independent factors expected to affect bee communities (abundance and or species richness).

Prior for conducting analyses, Kolmogorov-Smirnov test was used to check if variables were normally distributed. Data was transformed if found necessary to meet the assumption of normality and homogeneity of variances. Variable data expressed as percentages were arcsine square-root $(+0.5)$ 
transformed. The number of species and of individuals were square root +1 transformed and log-transformed using $\ln$ $(x+1)$, respectively. Back-transformed data are reported $[22,23,30]$.

Simple regression methods were mainly applied to explore relationships between local (abundance and richness of wild and cultivated floral resources) and landscape (cultivation intensity, amount of semi-natural habitats, and forest distance) variables and the abundance and species richness of bees. Scatter plots were used to illustrate scale dependency of bees on different local and landscape variables measured. Therefore, for all simple regression models obtained, the coefficient of determinations $\left(R^{2}\right)$ (that measures the proportion of the total variance of observed data explained by predicted data) was calculated to demonstrate the level of influence of the type of variables that correlate with the abundance and species richness of bees. In other words, the coefficient of determination $\left(R^{2}\right)$ was used for determining the proportion (\%) of influence of all different variables on the abundance and species richness of bees. Relationship between the density of nests and bee abundance/species was explored using simple regression analysis in Minitab15. All simple regression analyses were conducted in Minitab version-15 and the results plotted.

When interested in distinguishing/exploring the combined (simultaneous) effects of multiple predictor variables (local, landscape, and climatic variables) on bee communities (species richness and abundance), generalized linear models (GLMs) were performed. Models were computed including (i) local, landscape, and climatic variables as predictor variables; (ii) bee species richness or abundance as continuous/response variable. Generalized linear models (GLMs), with normal error distribution and log-link function, followed by a likelihood ratio test, and with three iteration levels, were fitted given the type of measured response (which changes may change scale from discrete counts to continuous frequency). The generalized linear modelling (GLM) framework was constructed in STATA version 8 for windows. Models were simplified using the Akaike's Information Criterion (AIC) and a drop function of variables for collinearity reasons (if any). The significance of the simultaneous effects of different variables was tested using $Z$ test.

The effects of categorical predictors (land-use intensity gradient categories) on bee species richness and abundance were analyzed by applying a general linear model (GLM). Analysis of variance (ANOVA) in Minitab statistical software version-15 was conducted with bee community variables (abundance and species richness) as the dependent variables, and the categorical variables (low, medium, high, and very high) as fixed factors. The Tukey tests were used as post hoc tests at $P<0.05$. Differences between means were inspected using Tukey's honestly significant difference (HSD).

\section{Results}

3.1. Characteristics of Bee Assemblages. In total, 652 species, (Table 8) representing 76 genera were recorded, and these comprised a total of 80883 individuals recorded. For data collection, three bee sampling methods of different efficiency and accuracy levels were employed in this study. Most bees Tables 8 and 9 were recorded through transect counts $(85 \%$ of total individuals), and very few individuals were captured by hand-net (8\%) and pan-traps (7\%). Although hand-net had significantly high bee species than pan-traps, the two methods recorded almost equal number of bee individuals. Total of 59, 314, and 559 bee species were recorded in transect counts, pan-traps, and hand-nets, respectively. Thus, transect count was not accurate in estimating species richness as compared to hand-net and pan-trap. The majority of bee species registered were native. There was no managed bee species. Population of honey bees encountering foraging during field is a population from wild established colonies and not from colonies established in hives.

Overall, bee species richness assessment was incomplete as taxon accumulation curves did not achieve asymptotes. Species richness was still increasing at the end of the sampling period and never reached the asymptote. The number of observed species was 652 species, whereas the average projected true species richness estimated was of 931 species according to Jacknife-1 estimator. Estimates of the expected richness indicated that $70 \%$ of the species present at the sampling sites during the period of study were found.

The most species-rich genera were Megachile (12.5\% of total species recorded), Lasioglossum (8.5\%), Lipotriches (6.2\%), Patellapis (5.8\%), Scrapter (5.7\%), Nomia (5.4\%) and Ceratina (5.1\%). Similarly, Megachilini (14.42\%), Halictini (11.7\%), Anthophorni (8.2\%), Allodapini (7.94\%), Ceratini (7.18\%), Anthidiini (6.35\%), Eucerini (5.05\%), and Xylocopini (5.05\%) tribes were the most species-rich and abundant taxa. The abundant and most widespread $(>5 \%$ of total individuals recorded) bee species were Apis mellifera adansonii Linnaeus (23.20\%), Hypotrigona gribodoi Magretti (18.89\%), Meliponula ferruginea Lepeletier (12.54\%), Lasioglossum ugandicum Cockerell 6.90\%), Apis mellifera scutellata Latreille (5.92\%), Allodapula acutigera Cockerell (5.89\%), Ceratina rufigastra Cockerell (5.60\%), Braunsapis angolensis Cockerell (5.29\%), and Seladonia jucundus Smith (5.02\%). Most bee species observed were polylectic; that is, they forage for pollen on a diverse array of plant species, and few of them were oligolectic bees. Most species were shorttongued species. Moreover, the community was dominated by ground-nesting species, whereas above-ground nesting species were rare.

Approximately 17 bee species were identified as ubiquitous and "ecologically characteristic" of the coffee-banana agroforests of central Uganda. These included Apis mellifera adansonii, Hypotrigona gribodoi, Meliponula ferruginea, Lasioglossum trichardti Cockerell, Apis mellifera scutellata, Lipotriches dentipes Friese, Lasioglossum ugandicum, Braunsapis angolensis, Heriades speculiferus Cockerell, Seladonia jucundus Smith, Meliponula nebulata Smith, Ceratina rufigastra Cockerell, Ceratina tanganyicensis Strand, Allodapula acutigera, Nomia atripes Friese, Allodape microsticta Cockerell, and Halictus frontalis Smith.

Although the different bee sampling methods used prevent direct comparison, the data indicate that the study area 
harbours one of the most diverse bee faunas in central and East Africa. Factors likely favouring the high bee diversity in this area include moderated climate and diversity of land use and related semi-natural habitats within agricultural matrix.

\subsection{Individual and Combined Effects of Various Factors on} Bee Community Parameters. Climatic factors (rainfall, minimum and maximum temperatures) were cross-correlated with bee community parameters (abundance and species richness) and with several local and landscape variables measured. The correlation between rainfalls/temperatures of years 2004, 2005 and 2006 with current abundance and species richness was determined since it has previously been observed that, most often, current afrotropical pollinator communities structures are also the reflect of variability in previous climatic events $[17,18,53]$.

Thus, bee community was strongly correlated with some climatic variables. In fact, rainfalls of year 2005 was found to be negatively correlated with both species richness $(r=$ $-0.61, P<0.001, n=26)$ and abundance $(r=-0.44$, $P<0.05, n=26$ ) of bees. Thus, bee species richness and abundance were significantly and negatively associated with precipitation in previous (not the current) year. Previous year is likely to be the stronger predictor of bee species richness (not bee abundance) in central Uganda. In other words, cumulative precipitation in the previous year is likely to be a good predictor of bee richness in the current year. Also, the mean rainfall of year 2006 was negatively correlated to species richness $(r=-0.50, P<0.001, n=26)$ abundance ( $r=-0.46, P<0.05, n=26)$ of bees. By the contrast, the abundance and species richness of bees were not significantly $(P>0.05)$ associated with the mean rainfall of year 2007 and with the overall mean rainfall of 10 years (Table 1). In addition bee abundance was negatively correlated with both the mean maximum temperature of 10 years $(r=-0.51$, $P<0.05, n=26)$, and mean maximum temperature of year $2005(r=-0.52, P<0.05, n=26)$; but positively correlated with both the mean minimum temperature of 10 years $(r=-0.49, P<0.05, n=26)$, and with the mean minimum temperature of year $2006(r=-055, P<0.001$, $n=26$; Table 1).

Results of the generalized linear model (GLM), applied to explore the simultaneous of multiple factors, revealed few significant $(P<0.05)$ predictor variables with combined and or interactive effects on bee species richness. Variables with combined negative/positive effects included the distance to forest, overall 10 -years monthly mean rainfalls, mean monthly rainfalls of year 2006 and mass flowering wild plant resources. Variables with significant combined negative/positive effects on bee abundance included (i) overall daily mean minimum temperature mean of 10 years, (ii) mean monthly rainfalls 2007 , (iii) mean monthly rainfalls 2006, (iv) number of flowering plant species, (v) mass blooming wild plant species, (vi) overall daily mean minimum temperature mean of 10 years (vii) proportion cultivation intensity, (iix) mean monthly maximum temperature, (ix) cultivated floral resources with positive, $(\mathrm{x})$ mean monthly minimum temperature of year 2006 with, the percent cover of semi-natural habitats, and so forth (Table 2). These GLMs also indicated that current trend in occurrence of bee species richness and abundance is the consequence of various interacting factors operating at different scale levels but with simultaneous negative/positive effects.

Simple linear regression analysis revealed that floral resources exhibited positive and significant relationships with bee abundance and species richness. Bee species richness and abundance were related to richness and abundance of wild blooming plants. Bee species richness was also related to the abundance cultivated floral resources. The list of pollinator-dependent and non-pollinator dependent crops grown in Uganda is presented in Table 6. Several wild blooming plant species were registered during the course of the study (Table 7). In addition, there was a seasonal variability in richness and abundance of wild blooming plant species (Figure 2). Across the five rounds of data collection, there was variability in cultivated and noncultivated floral resources following different environmental conditions found in the different study sites.

Species richness (not the abundance) of cultivated crops decreased linearly $\left(R^{2}=0.226, n=26, P<0.001\right)$ with cultivation intensity. A reverse trend $\left(R^{2}=0.198\right.$, $n=26, P<0.05$ ) was observed for wild blooming plants (herbs, weeds, etc.). Species richness (not the abundance) of wild blooming plants increased linearly with increase in $\%$ cover of semi-natural habitats $\left(R^{2}=0.293, n=26\right.$, $P<0.001)$ but declined linearly with forest distance $\left(R^{2}=\right.$ $0.455, n=26, P<0.001)$. These results indicated that isolated sites or overcultivated sites were associated with low species richness in flowering plant species although, at some times, abundant mass blooming crops could be observed in overcultivated areas or in areas located very far from forests. On the contrast, areas that were covered by a high proportion of semi-naturals were also associated with high species richness of wild blooming plants and not necessarily with abundant blooming plant populations.

The results of simple linear and non-linear regressions (quadratic regressions) indicated that percent of wild floral resources (blossom cover) was significant and positively related to both species richness (Figure 3(a)) and abundance (Figure 3(b)) of bees. This result suggested that the amount of wild floral resources played a critical role in shaping flowervisiting bee communities in agricultural landscapes of central Uganda. Overall, wild blossoms (from wild blooming plants) cover explained $86 \%$ and $61 \%$ of variation in bee species richness and in bee abundance, respectively. Interestingly, flowering wild plant species richness was significantly $(P<$ 0.05 ) related to bee species richness (Figure 3(c)) but was not significantly $(P>0.05)$ related to bee abundance (Figure 3(d)). The number of wild blooming plant species accounted for $19.6 \%$ of variation in bee species richness. These results indicated that increase in the diversity of flowering plant species can attract a high number of bee species; however, beyond 30 plant species, bee species richness can start to drop. The drop in bee species richness was unexpected and may be difficult to explain since at some points there is an expected plateau due to carrying capacity. In other words, bee 
TABLE 1: Cross-correlation matrix showing naïve multiple correlations of Apoidea (bee) variables with environmental, local, and landscape variables (different levels of significance of Spearman rank of correlation coefficients: ${ }^{*} P<0.05 ;{ }^{* *} P<0.001$; otherwise not significant when no value given).

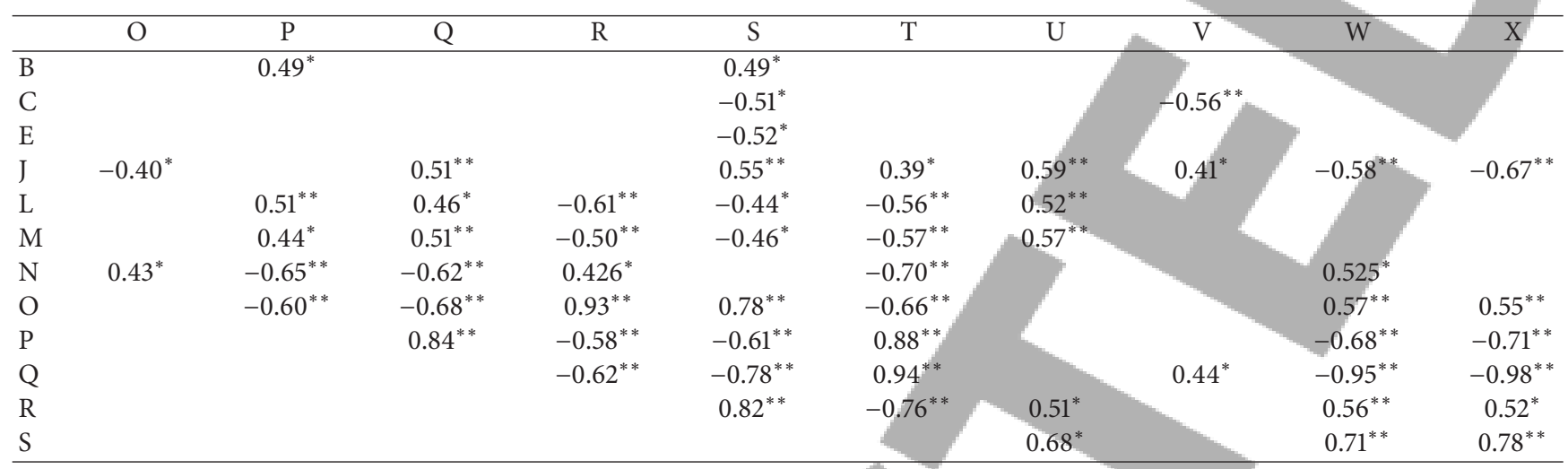

Legend: $\mathrm{A}=$ overall mean rainfalls (means/month/10 years); $\mathrm{B}=$ overall daily mean minimum temperature (mean 10 years); $\mathrm{C}=$ overall daily mean maximum temperature (mean 10 years ); $\mathrm{D}=$ mean monthly rainfalls (2007); $\mathrm{E}=$ mean monthly maximum temperature (2005); $\mathrm{F}=$ mean monthly maximum temperature (2006); $\mathrm{H}=$ mean monthly maximum temperature (2007); I = mean monthly minimum temperature (2005); J = mean monthly minimum temperature (2006); $\mathrm{K}=$ mean monthly minimum temperature (2007); $\mathrm{L}=$ mean monthly rainfalls (2005); $\mathrm{M}=$ mean monthly rainfalls (2006); $\mathrm{N}=$ wild flowering plant species richness; $\mathrm{O}=$ density of plant species; $\mathrm{P}=$ human population density; $\mathrm{Q}=$ proportion cultivation intensity; $\mathrm{R}=$ mean bee species richness; $\mathrm{S}=$ mean bee abundances; $\mathrm{T}=$ forest distance $(\mathrm{m}) ; \mathrm{U}=$ cultivated with floral resources (pollinator-dependent crops); $\mathrm{V}=$ cultivated without resources (pollinator nondependent crops); $\mathrm{W}=\%$ seminatural habitats/site; $\mathrm{X}=\%$ young fallows per site.

species richness response to richness of wild floral resources richness is not necessarily linear under local conditions in Uganda.

As expected, the cover of cultivated non-pollinatordependent floral resources was not significantly $\left(R^{2}=\right.$ $0.122, n=26, P>0.05$ ) related to either bee species richness or to bee abundance. Yet, the percentage cover of cultivated non-pollinator-dependent crops decreased as bee species richness and/or abundance increased. Conversely, the number of species of cultivated non-pollinatordependent floral resources was not related $(P>0.05)$ to bee species richness (Figure 3(e)) and/or abundance (Figure 3(f)) under local conditions in central Uganda. Practically, cultivated pollinator-dependent floral resources were significantly $(P<0.05)$ and positively related to bee species richness (Figure 3(e)) and bee abundance (Figure 3(f)). The proportion of cultivated pollinator-dependent crops explained $26 \%$ and $47 \%$ of the variation in bee species and in bee abundance, respectively (Figure 3 ). This indicates that cultivated pollinator-dependent crops species provide sufficient pollen resources to bee communities visiting crop fields in the agricultural mosaics of central Uganda. In other worlds, species richness and population density of bees in the agricultural landscapes are also influenced by the abundance of cultivated pollinator-dependent crop floral resources. Although no clear relationships between cover of cultivated and cover of noncultivated pollinator-dependent crops in the local farm-landscape were detected, when farmers increased the land area dedicated to pollinator-dependent crops, cover of non-pollinator-dependent crops reduced in terms of area coverage. Overall, species richness and population density of bees in the agricultural landscapes were found to be largely influenced (were more predicted) by the percent cover of bloom of wild plant species than by the proportion of cultivated crops that are pollinator dependent.
The regression analysis revealed that some landscape factors showed highly significant $(P<0.05)$ associations with bee community parameters. Cultivation intensity was significantly $(P<0.05)$ and negatively related to both bee species richness (Figure 4(a)) and population density (Figure 4(b)). The proportion cultivation intensity explained $38 \%$ and $62 \%$ of variation in bee species richness and in bee abundance, respectively. These results suggested a "steep" (abrupt) "decline" (reduction) in bee species richness and abundance with cultivation intensity. The proportion of seminatural habitats in a $1 \mathrm{~km}^{2}$ area was significantly $(P<0.05)$ and positively related to both species richness (Figure $4(\mathrm{c})$ ) and abundance (Figure $4(\mathrm{~d})$ ) of bees. The proportion of seminatural habitats accounted for $31 \%$ and $50 \%$ of variation in bee species richness and in bee abundance respectively. This result suggested that any increase in amount of seminatural habitats in the landscape was likely to lead to an increase in the number of bee species and individuals in the agricultural matrices. Surprisingly, forest distance was significantly $(P<0.05)$ and negatively related to bee species richness (Figure $4(\mathrm{e}))$ but was not significantly $(P>$ 0.05 ) related to bee abundance (Figure $4(\mathrm{f})$ ). Forest distance explained $58 \%$ of the variation in bee species (Figure 4 ). This result suggested also that there was a strong decline in bee species with forest distance. In other words, study sites that were riparian of forest reserves harbored high species richness than did sites that were isolated or located far way from forest reserves.

3.3. Effects of Regional Land-Use Intensity Factors. There were significant $(P<0.01)$ effects of the different landuse categories on bee species richness (Figure 5(a)) and population density (Figure 5(b)). Bee species richness was on average significantly $(P<0.05)$ greater in study sites of low to 
TABLE 2: Generalized linear models (GLMs) testing the effects of local, landscape, and climatic factors on bee abundance and species richness in farmlands of central Uganda.

\begin{tabular}{|c|c|c|c|c|c|c|c|}
\hline & Bee species richness & Coef. & Std. Err. & $z$ & $P>|z|$ & $95 \%$ Con & f. Interval \\
\hline \multirow[t]{4}{*}{ Landscape variables } & Forest distance & -0.3040771 & 0.0372303 & -8.17 & 0.000 & -0.3770472 & -0.2311071 \\
\hline & Proportion cultivation intensity & -0.0417633 & 0.0184095 & -2.27 & 0.023 & -0.0778453 & -0.0568113 \\
\hline & $\%$ seminatural habitats & 0.0260201 & 0.0098786 & 2.63 & 0.008 & 0.0066585 & 0.0453817 \\
\hline & $\begin{array}{l}\text { Human population density } \\
\text { (inhabitants } / \mathrm{Km}^{2} \text { ) }\end{array}$ & 0.0136742 & 0.0417017 & 033 & 0743 & -0068 & 0.0954081 \\
\hline \multirow[t]{8}{*}{ Climatic variables } & $\begin{array}{l}\text { Overall daily mean minimum } \\
\text { temperature (mean } 10 \text { years) }\end{array}$ & -2.36636 & 2.509198 & & 0.346 & -7.284298 & 2.551578 \\
\hline & $\begin{array}{l}\text { Overall daily mean maximum } \\
\text { temperature (mean } 10 \text { years ) }\end{array}$ & -0.8994122 & 0.3635115 & & & & -0.1869429 \\
\hline & $\begin{array}{l}\text { Mean monthly maximum } \\
\text { temperature (2005) }\end{array}$ & -5.517305 & 5.026883 & -1.1 & 0.272 & 2 & 4.335206 \\
\hline & $\begin{array}{l}\text { Mean monthly maximum } \\
\text { temperature (2006) }\end{array}$ & -0.0751644 & 0.1294036 & & 0.561 & -0.3287908 & 0.178462 \\
\hline & $\begin{array}{l}\text { Mean monthly minimum } \\
\text { temperature (2006) }\end{array}$ & 0.023 & & & & -0.015209 & 0.0626443 \\
\hline & $\begin{array}{l}\text { Overall mean rainfall } \\
\text { (means/month/10 years) }\end{array}$ & 0.8934966 & 0.4196737 & 2.13 & 0.033 & 0.0709512 & 1.716042 \\
\hline & Mean monthly rainfalls (2007) & -5.14455 & 5.405548 & -0.95 & 0.341 & -15.73923 & 5.450129 \\
\hline & Mean monthly rainfalls (2006) & -0.9998961 & 0.3946438 & -2.53 & 0.011 & -1.773384 & -0.2264084 \\
\hline \multirow[t]{5}{*}{ Local variables } & $\begin{array}{l}\text { Density of wild plants } \\
\text { (weeds/herbs/trees) }\end{array}$ & 0.6940608 & 0.3129488 & 2.22 & 0.027 & 0.0806924 & 1.307429 \\
\hline & $\begin{array}{l}\text { Number of flowering wild plant } \\
\text { species (weeds/herbs/trees) }\end{array}$ & -2 & 0.8 & & 0.001 & -4.546496 & -1.202271 \\
\hline & $\begin{array}{l}\% \text { of cultivated floral resources } \\
\text { (pollinator-dependent crops) }\end{array}$ & 0.4345841 & 2.249894 & 0.19 & 0.847 & -3.975128 & 4.844296 \\
\hline & $\begin{array}{l}\% \text { cultivated floral resources } \\
\text { (nonpollinator-dependent crops) }\end{array}$ & & 2.129935 & 0.41 & 0.685 & -3.309331 & 5.039861 \\
\hline & Constant & 548.8108 & 500.5592 & 1.1 & 0.273 & -432.2671 & 1529.889 \\
\hline
\end{tabular}

Other statistics: Log likelihood = -124.727761; AIC (Akaike’s Information Criterion) =12.70252; BIC $($ Schwarz's Bayesian Criterion $)=$ $-21.62718472$

\begin{tabular}{|c|c|c|c|c|c|c|c|}
\hline & Bee abundance & & & & & & \\
\hline \multirow[t]{4}{*}{ Landscape variables } & Forest distance & 0.0039313 & 0.0054335 & 0.72 & 0.4669 & -716.9601 & 0.0145808 \\
\hline & Proportion cultivation intensity & -613.0046 & 180.3214 & -3.4 & 0.001 & -966.4281 & -259.5811 \\
\hline & $\%$ of seminatural habitats & 0.001616 & 0.0001599 & 10.10 & 0.000 & 0.0013026 & 0.0019295 \\
\hline & $\begin{array}{l}\text { Overall monthly mean rainfalls } \\
\text { (means of } 10 \text { years) }\end{array}$ & 26.26025 & 2.734129 & 9.6 & 0.000 & -19.34479 & 31.61905 \\
\hline \multirow[t]{12}{*}{ Climatic variables } & $\begin{array}{l}\text { Overall daily mean minimum } \\
\text { temperature (mean of } 10 \text { years) }\end{array}$ & & 18.25537 & -20.66 & 0.000 & -9.023715 & -341.3545 \\
\hline & $\begin{array}{l}\text { Overall daily mean maximum } \\
\text { temperature (mean of } 10 \text { years ) }\end{array}$ & -383.902 & 169.9307 & -2.26 & 0.024 & -716.9601 & -50.84403 \\
\hline & $\begin{array}{l}\text { Mean monthly minimum } \\
\text { temperature }(2006)\end{array}$ & -263.8625 & 35.75006 & -7.38 & 0.000 & -333.9313 & -193.7937 \\
\hline & $\begin{array}{l}\text { Overall daily mean minimum } \\
\text { temperature mean } 10 \text { years }\end{array}$ & 5.595728 & 0.3103008 & 18.03 & 0.000 & 4.98755 & 6.203907 \\
\hline & $\begin{array}{l}\text { Mean monthly maximum } \\
\text { temperature (2005) }\end{array}$ & -66.88049 & 32.75358 & -2.04 & 0.041 & -131.0763 & -2.684648 \\
\hline & Mean monthly rainfalls (2007) & -14.75942 & 2.339518 & -6.31 & 0.000 & -19.34479 & -10.17404 \\
\hline & Mean monthly rainfalls (2006) & -5.413767 & 1.841844 & -2.94 & 0.003 & -9.023715 & -1.803819 \\
\hline & $\begin{array}{l}\text { Mean number of flowering wild } \\
\text { plant species }\end{array}$ & -4.652631 & 4.882926 & -0.95 & 0.341 & -14.22299 & 4.917729 \\
\hline & $\begin{array}{l}\text { Mean density of wild flowering } \\
\text { plants }\end{array}$ & 1.686491 & 0.1404906 & 12 & 0.000 & 1.411134 & 1.961847 \\
\hline & $\begin{array}{l}\text { Cultivated floral resources } \\
\text { (pollinator dependent crops) }\end{array}$ & -192.0184 & 16.07023 & -11.95 & 0.000 & -223.5154 & -160.5213 \\
\hline & $\begin{array}{l}\text { Cultivated-without resources } \\
\text { (nonpollinator-dependent crops) }\end{array}$ & 0.1851433 & 0.1925751 & 0.9611 & 0.336 & -0.192297 & 0.5625835 \\
\hline & Constant & 36034.16 & 3331.619 & 10.82 & 0.0000 & 29504.3 & 42564.01 \\
\hline
\end{tabular}

Other statistics: Log likelihood = -390.1545969; AIC (Akaike's Information Criterion) = 36.83224; BIC (Schwarz's Bayesian Criterion ) = 568.065439 
TABLE 3: Richness and abundance of bees attracted to different habitats (land uses) frequently observed in the coffee-banana farming systems of central Uganda. Most attractive habitats were those with $>20 \%$ of weeds/crops/grass/wild plant species blooming at the time of visit.

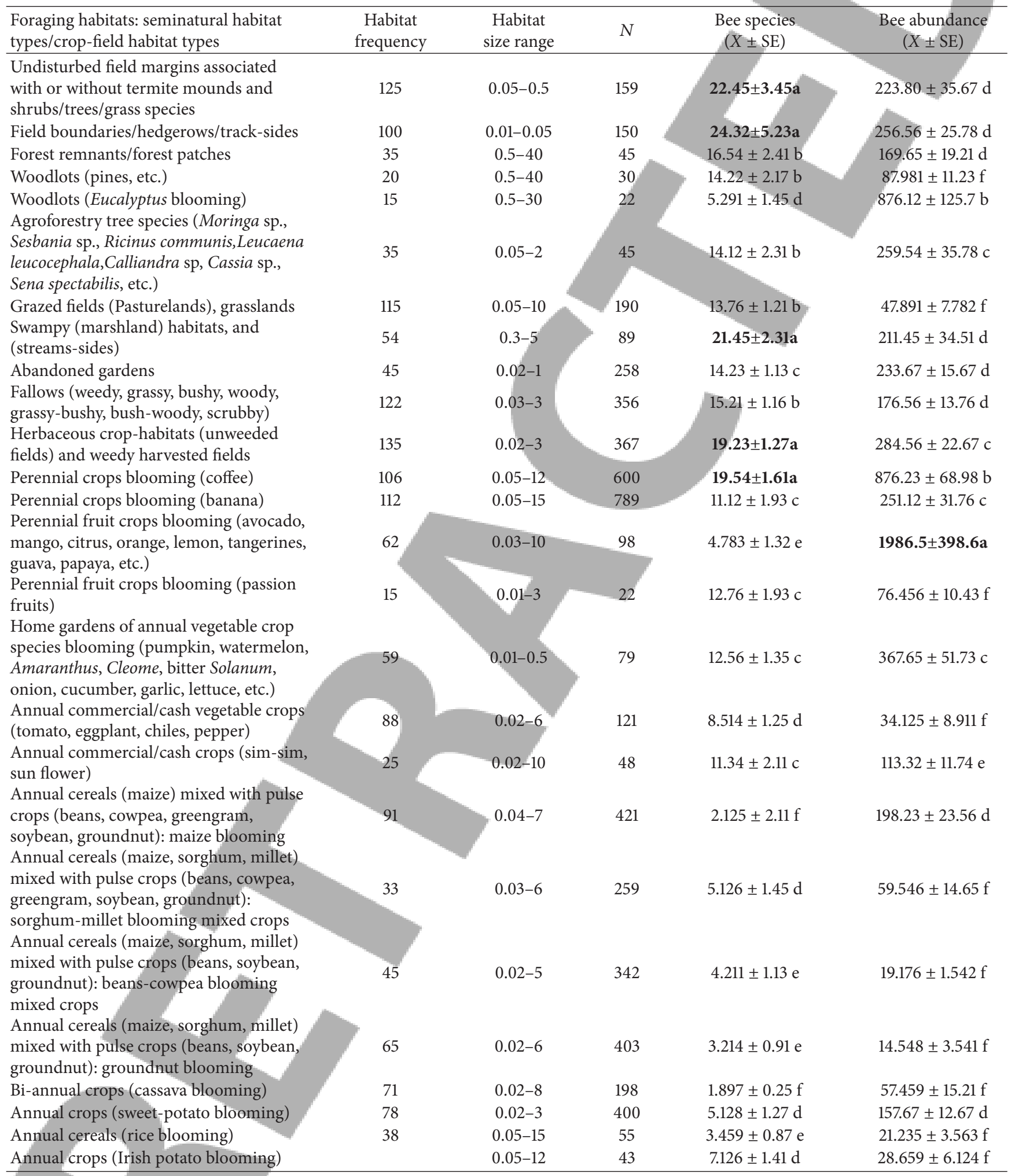

Habitat frequency = number of observation cases or number of times the habitat type was encountered across all 26 study sites and all sampling rounds. Habitat size range $(\mathrm{ha})=$ the data show the minimum and the maximum size of the type of habitat encountered during butterfly faunistic surveys. $N=$ number of samples (bees species and individuals) recorded in five sampling rounds across the 26 study sites in 2006.

Within columns, different letters show significant differences of the means at $P=0.05$ according to Tukey test performed after Kruskall-Walis ANOVA test indicating that the habitat type was significant $(P<0.01)$ for the number of species and individuals attracted. 
Psyche

TABle 4: Density $(x \pm s d$ ) of bee nests (number of individual bee nests counted during transects walks and counts different farmland habitats/land-uses) per nesting type.

\begin{tabular}{|c|c|c|c|c|c|c|c|}
\hline $\begin{array}{l}\text { Types of seminatural } \\
\text { habitats/land-uses } \\
\text { (bee reservoirs/refugia) }\end{array}$ & $\begin{array}{l}\text { Habitat size } \\
\text { (ha) }\end{array}$ & Bee hives & Foliage nests & Ground-nests & $\begin{array}{l}\text { Termite } \\
\text { mounds }\end{array}$ & $\begin{array}{l}\text { House-wall } \\
\text { nests }\end{array}$ & $\begin{array}{l}\text { Wood/tree } \\
\text { nests }\end{array}$ \\
\hline Roadsides/track-sides & & & & & $\begin{array}{l}12.21 \pm 4.5(n \\
* *=125)\end{array}$ & $\begin{array}{l}125.7 \pm 78 \\
\left(n^{* * *}=15\right)\end{array}$ & $\begin{array}{c}2.57 \pm 0.78(n \\
*=5)\end{array}$ \\
\hline $\begin{array}{l}\text { Hedgerows, field boundaries } \\
\text { (field margins) }\end{array}$ & $0.21 \pm 0.05$ & $\begin{array}{l}1.00 \pm 0.00 \\
(n=2)\end{array}$ & & $\begin{array}{l}12.7 \pm 7.8(n \\
* * * *=45)\end{array}$ & $\begin{array}{l}125.7 \pm 87 \\
(n=115)\end{array}$ & & $\begin{array}{c}2.5 \pm 1.8 \\
(n=6)\end{array}$ \\
\hline $\begin{array}{l}\text { Small tropical forest } \\
\text { remnants/forest patches }\end{array}$ & $7.22 \pm 21.6$ & $\begin{array}{c}5.7 \pm 3.4 \\
(n=4)\end{array}$ & $\begin{array}{l}1.5 \pm 1.1 \\
(n=5)\end{array}$ & $\begin{array}{c}18.1 \pm 4.6 \\
(n=25)\end{array}$ & $\begin{array}{l}9.1 \pm 4.6 \\
(n=25)\end{array}$ & & $\begin{array}{c}15.7 \pm 3.1 \\
(n=24)\end{array}$ \\
\hline Ecotones/edge of forest reserves & $1.84 \pm 0.21$ & & $\begin{array}{c}2.2 \pm 1.4 \\
(n=6)\end{array}$ & $\begin{array}{l}2.2 \pm 1.4 \\
(n=6)\end{array}$ & $\begin{array}{c}16.2 \pm 1.4 \\
(n=6)\end{array}$ & $\begin{array}{l}725.7 \pm 278 \\
(n=25)\end{array}$ & $\begin{array}{c}35.7 \pm 13.1 \\
(n=11)\end{array}$ \\
\hline $\begin{array}{l}\text { Woodlots (pines/eucalyptus) and } \\
\text { woodlands }\end{array}$ & $9.45 \pm 34.78$ & $\begin{array}{c}3.2 \pm 1.4 \\
(n=8)\end{array}$ & & $43.2 \pm 21.4$ & $\begin{array}{l}23.2 \pm 11.6 \\
(n=38)\end{array}$ & $\begin{array}{l}25.3 \pm 2.8 \\
(n=5)\end{array}$ & $\begin{array}{c}53.2 \pm 31.4 \\
(n=88)\end{array}$ \\
\hline Edge of wetlands/streams & $0.91 \pm 2.12$ & & $\begin{array}{l}1.00 \pm 0.0 \\
(n=3)\end{array}$ & $\begin{array}{l}19.34 \pm 12.5 \\
(n=23)\end{array}$ & $\begin{array}{l}2.2 \pm 1.1 \\
(n=5)\end{array}$ & & $\begin{array}{l}3.2 \pm 1.1 \\
(n=8)\end{array}$ \\
\hline Abandoned gardens & $0.06 \pm 0.04$ & $\begin{array}{c}1.2 \pm 0.7 \\
(n=4)\end{array}$ & & $\begin{array}{l}9.4 \pm 5.5 \\
(n=16)\end{array}$ & $\begin{array}{l}4.2 \pm 1.2 \\
(n=10)\end{array}$ & $\begin{array}{c}421.7 \pm 367 \\
(n=6)\end{array}$ & $\begin{array}{l}11.57 \pm 1.78 \\
(n=15)\end{array}$ \\
\hline $\begin{array}{l}\text { Fenced cattle keeping fields, large } \\
\text { pasturelands }\end{array}$ & $9.43 \pm 4.91$ & & & $\begin{array}{l}13.1 \pm 3.5 \\
(n=13)\end{array}$ & $\begin{array}{c}10.2 \pm 7.2 \\
(n=13)\end{array}$ & & $\begin{array}{l}27.7 \pm 12.7 \\
(n=17)\end{array}$ \\
\hline $\begin{array}{l}\text { Lantanacamara/Erlangea } \\
\text { tomentosa fallows }\end{array}$ & $0.45 \pm 1.29$ & & & $\begin{array}{c}53.1 \pm 13.5 \\
(n=63)\end{array}$ & $\begin{array}{c}17.2 \pm 4.2 \\
(n=11)\end{array}$ & & $\begin{array}{l}7.2 \pm 2.1 \\
(n=7)\end{array}$ \\
\hline Swampy fallows (different ages) & $4.45 \pm 1.29$ & & $42+14$ & $\begin{array}{c}3.1 \pm 1.5 \\
(n=6)\end{array}$ & $\begin{array}{c}3.1 \pm 1.2 \\
(n=5)\end{array}$ & & $\begin{array}{l}17.2 \pm 12.1 \\
\quad(n=7)\end{array}$ \\
\hline Forest fallows ( $>5-7$ years) & $4.32 \pm 24.31$ & & $1.00 \pm 0.00$ & $\begin{array}{l}45.1 \pm 21.5 \\
(n=12)\end{array}$ & $\begin{array}{l}13.1 \pm 7.1 \\
(n=15)\end{array}$ & & $\begin{array}{l}47.2 \pm 32.1 \\
(n=17)\end{array}$ \\
\hline Young fallow ( $<1-2$ years aged) & 0.06 & & & $\begin{array}{c}39.3 \pm 11.5 \\
(n=78)\end{array}$ & $\begin{array}{l}4.1 \pm 2.1 \\
(n=45)\end{array}$ & & $\begin{array}{l}11.2 \pm 2.1 \\
(n=65)\end{array}$ \\
\hline Small and large grasslands & & & & $\begin{array}{c}25.3 \pm 5.6 \\
(n=18)\end{array}$ & $\begin{array}{l}2.1 \pm 1.1 \\
(n=15)\end{array}$ & & $\begin{array}{l}2.2 \pm 1.1 \\
(n=15)\end{array}$ \\
\hline $\begin{array}{l}\text { Small grazing fields (for small } \\
\text { ruminants) }\end{array}$ & & & & $\begin{array}{l}5.3 \pm 2.6 \\
(n=8)\end{array}$ & $\begin{array}{l}1.7 \pm 0.86 \\
(n=4)\end{array}$ & & $\begin{array}{c}1.2 \pm 0.5 \\
(n=5)\end{array}$ \\
\hline $\begin{array}{l}\text { Simple agroforestry systems } \\
\text { (agroforestry trees + fruits) }\end{array}$ & & & & $\begin{array}{l}2.3 \pm 1.2 \\
(n=45)\end{array}$ & $\begin{array}{c}1.1 \pm 0.46 \\
(n=25)\end{array}$ & $\begin{array}{c}321.7 \pm 167 \\
(n=16)\end{array}$ & $\begin{array}{c}21.2 \pm 10.5 \\
(n=15)\end{array}$ \\
\hline $\begin{array}{l}\text { Complex agroforests (agroforest } \\
\text { trees + fruits + native trees) }\end{array}$ & & $\begin{array}{l}2.4 \\
10)\end{array}$ & & $\begin{array}{l}3.1 \pm 1.3 \\
(n=48)\end{array}$ & $\begin{array}{l}2.5 \pm 1.2 \\
(n=25)\end{array}$ & $\begin{array}{l}821.7 \pm 461 \\
(n=9)\end{array}$ & $\begin{array}{l}29.1 \pm 20.5 \\
(n=19)\end{array}$ \\
\hline $\begin{array}{l}\text { Perennial crops associated } \\
\text { headed by coffee }+ \text { banana }\end{array}$ & 0.87 & $\begin{array}{l}3.2 \pm 1.1 \\
(n=5)\end{array}$ & & $\begin{array}{l}12.3 \pm 5.6 \\
(n=38)\end{array}$ & $\begin{array}{l}1.8 \pm 1.2 \\
(n=24)\end{array}$ & $\begin{array}{c}456.6 \pm 121 \\
(n=7)\end{array}$ & $\begin{array}{c}21.2 \pm 11.5 \\
(n=25)\end{array}$ \\
\hline $\begin{array}{l}\text { Homegardens with annual } \\
\text { vegetable crop species }\end{array}$ & & & & $\begin{array}{c}1.0 \pm 0.0 \\
(n=1)\end{array}$ & $\begin{array}{c}1.0 \pm 0.0 \\
(n=1)\end{array}$ & $\begin{array}{c}399.7 \pm 111 \\
(n=11)\end{array}$ & $\begin{array}{c}1.2 \pm 0.5 \\
(n=4)\end{array}$ \\
\hline $\begin{array}{l}\text { Marshland habitats and } \\
\text { reclaimed wetlands }\end{array}$ & & & & $\begin{array}{l}4.1 \pm 1.2 \\
(n=5)\end{array}$ & $\begin{array}{c}1.0 \pm 0.0 \\
(n=1)\end{array}$ & & $\begin{array}{c}1.9 \pm 0.7 \\
(n=6)\end{array}$ \\
\hline $\begin{array}{l}\text { Bi-annual root crops (Cassava) } \\
\text { fields }\end{array}$ & & & & $\begin{array}{l}1.1 \pm 0.1 \\
(n=5)\end{array}$ & $\begin{array}{l}2.00 \pm 0.0 \\
(n=2)\end{array}$ & $\begin{array}{c}323.1 \pm 145 \\
(n=7)\end{array}$ & $\begin{array}{l}1.00 \pm 0.00 \\
\quad(n=1)\end{array}$ \\
\hline $\begin{array}{l}\text { Annual root/tuber crops (sweet } \\
\text { potato) fields }\end{array}$ & & & & $\begin{array}{l}7.1 \pm 2.1 \\
(n=15)\end{array}$ & $\begin{array}{l}2.00 \pm 0.0 \\
(n=2)\end{array}$ & $\begin{array}{c}723.1 \pm 345 \\
(n=5)\end{array}$ & $\begin{array}{c}3.9 \pm 1.7 \\
(n=6)\end{array}$ \\
\hline $\begin{array}{l}\text { Annual cereal (maize, sorghum, } \\
\text { rice) }+ \text { legume (bean, groundnut) } \\
\text { crops }\end{array}$ & $0.41 \pm 2.765$ & & & $\begin{array}{l}1.6 \pm 0.6 \\
(n=11)\end{array}$ & $\begin{array}{c}1.0 \pm 0.0 \\
(n=1)\end{array}$ & $\begin{array}{l}412.1 \pm 156 \\
\quad(n=8)\end{array}$ & $\begin{array}{l}2.2 \pm 1.2 \\
(n=16)\end{array}$ \\
\hline
\end{tabular}

The density is the number of nests counted per nesting site per 5 ha-transect. The data reflect the number of observations or number of time this nest was recorded in five rounds of data collection conducted during 2006 in central Uganda. $n=$ the number of time the individual bee nest was recorded in a particular land-use/habitat type during five rounds of data collection across 26 study sites. Number of individual bee nests included all type of solitary and social bee species and all type of bee nests location combined.

$n^{* * * *}=$ number of active ground nets recorded in that habitat; $n^{* *}=$ number of active termite mounds recorded in that habitat; $n^{* * *}=$ number of active nests counted on house wall (old houses, nests, livestock houses, abandoned or not) established near the habitat described; $n^{*}=$ number of active wood/tree nests seen and counted during transect walks. 
TABLE 5: Density (number of trees/5 ha) of nest tree species recorded in farmlands of central Uganda during bee faunistic surveys conducted in 2006. Data are means of 26 study sites and five sampling rounds conducted in 2006.

\begin{tabular}{|c|c|c|}
\hline Family & Species name & $\begin{array}{c}\text { Density of trees } \\
(\text { Mean } \pm \text { SD })\end{array}$ \\
\hline Caesalpiniaceae & Senna occidentalis & $236.92 \pm 34.76$ \\
\hline Bignoniaceae & Markhamia lutea & $188.82 \pm 4.11$ \\
\hline Myrsinaceae & Maesa lanceolata & $146.222 \pm 34.67$ \\
\hline Asteraceae & Vernonia amygdalina & $133.23 \pm 76.1$ \\
\hline Myrtaceae & Psidium guajava & $109.06 \pm 45.7$ \\
\hline Moraceae & Ficus saussureana & $87.31 \pm 5.87$ \\
\hline Lauraceae & Persea americana & $87.31 \pm 56.91$ \\
\hline Anacardiaceae & Mangifera indica & $77.34 \pm 6.76$ \\
\hline Myrtaceae & Eucalyptus grandis & $67.97 \pm 5.67$ \\
\hline Tiliaceae & Theobroma cacao & $67.97 \pm 45.12$ \\
\hline Papilionaceae & Erythrina abyssinica & $24.47 \pm 10.11$ \\
\hline Proteaceae & Grevillea robusta & $19.33 \pm 8.98$ \\
\hline Solanaceae & Solanum wrightii & $19.33 \pm 5.67$ \\
\hline Caesalpiniaceae & Cassia spectabilis & $14.80 \pm 65.2$ \\
\hline Cupressaceae & Cupressus lusitanica & $14.80 \pm 9.56$ \\
\hline Moraceae & Ficus mucuso & $14.80 \pm 7.54$ \\
\hline Mimosaceae & Leucaena leucocephala & $10.87 \pm 13.89$ \\
\hline Bignoniaceae & Spathodea campanulata & $10.87 \pm 8.98$ \\
\hline Rutaceae & Citrus lemon & $7.55 \pm 7.65$ \\
\hline Apocynaceae & Funtumia africana & $7.55 \pm 5.43$ \\
\hline Mimosaceae & Calliandra calothyrsus & $4.83 \pm 3.45$ \\
\hline Bignoniaceae & Jacaranda mimosifolia & $4.83 \pm 3.12$ \\
\hline Euphorbiaceae & Bridelia micrantha & $2.71 \pm 1.12$ \\
\hline Moraceae & Ficus thonningii & $2.72 \pm 2.34$ \\
\hline Bignoniaceae & Kigelia africana & $2.71 \pm 5.12$ \\
\hline Euphorbiaceae & $\begin{array}{l}\text { Macaranga } \\
\text { schweinfurthii }\end{array}$ & $2.71 \pm 5.12$ \\
\hline Papilionaceae & Sesbania sesban & $2.71 \pm 3.45$ \\
\hline Mimosaceae & Albizia chinensis & $1.21 \pm 1.23$ \\
\hline Mimosaceae & Albizia coriaria & $1.20 \pm 4.54$ \\
\hline Rubiaceae? & Coffeacanephora & $1.20 \pm 5.65$ \\
\hline Caesalpiniaceae & Senna spectabilis & $1.20 \pm 1.23$ \\
\hline Mimosaceae & Acrocarpus fraxinifolius & $1.33 \pm 5.12$ \\
\hline Mimosaceae & Albizia glaberrima & $1.50 \pm 2.54$ \\
\hline Mimosaceae & Albizia grandibracteata & $1.90 \pm 4.12$ \\
\hline Mimosacea & Albizia gummifera & $1.30 \pm 5.32$ \\
\hline Moraceae & Artocarpus heteroph & $1.30 \pm 2.12$ \\
\hline Meliaceae & Azadirachta indica & $1.30 \pm 3.45$ \\
\hline Caesalpiniaceae & Cassia siamea & $1.30 \pm 3.23$ \\
\hline Ulmaceae & Celtis africana & $0.90 \pm 2.12$ \\
\hline Ulmaceae & Celtis mildbraedii & $0.83 \pm 3.12$ \\
\hline Rutaceae & Citrus sinensis & $0.81 \pm 3.12$ \\
\hline Palmae & Elaeis guineensis & $0.70 \pm 2.43$ \\
\hline Moraceae & Ficus asperifolia & $0.68 \pm 3.55$ \\
\hline Moraceae & Ficus barteri & $0.67 \pm 3.23$ \\
\hline
\end{tabular}

\begin{tabular}{|c|c|c|}
\hline Family & Species name & $\begin{array}{c}\text { Density of trees } \\
(\text { Mean } \pm \text { SD })\end{array}$ \\
\hline Moraceae & Ficus benjamina & $0.62 \pm 1.56$ \\
\hline Moraceae & Ficus brachypoda & $0.57 \pm 2.32$ \\
\hline Moraceae & Ficus cyathistipula & $0.50 \pm 1.14$ \\
\hline Moraceae & Ficus dicronystilla & $0.46 \pm 1.23$ \\
\hline Moraceae & Ficus exasperata & $0.40 \pm 1.54$ \\
\hline Moraceae & Ficus natalensis & $0.36 \pm 1.45$ \\
\hline Moraceae & Ficus ottoniifolia & $0.35 \pm 0.97$ \\
\hline Moraceae & Ficus polita & $0.34 \pm 0.76$ \\
\hline Moraceae & Ficus pseudomangifera & $0.33 \pm 6.71$ \\
\hline Moraceae & Ficus stipulifera & $0.31 \pm 4.56$ \\
\hline Moraceae & Ficus sur & $0.30 \pm 2.78$ \\
\hline Moraceae & Ficus sycomorus & $0.30 \pm 4.56$ \\
\hline Moraceae & Ficus valifolia & $0.29 \pm 5.76$ \\
\hline Moraceae & Ficus vasta & $0.28 \pm 3.61$ \\
\hline Mimosaceae & Grilicia sepium & $0.27 \pm 3.11$ \\
\hline Ulmaceae & Holopteria grandis & $0.26 \pm 2.71$ \\
\hline Rhamnaceae & Maesopsis eminii & $0.24 \pm 1.51$ \\
\hline Moringaceae & Moringa oleifera & $0.21 \pm 3.19$ \\
\hline Pinaceae & Pinus carribaea & $0.20 \pm 1.12$ \\
\hline Podocarpaceae & Podocarpus milinjuanus & $0.19 \pm 3.13$ \\
\hline Rosaceae & Prunus africana & $0.18 \pm 2.13$ \\
\hline Myrtaceae & Syzygium cuminii & $0.16 \pm 0.91$ \\
\hline Combretaceae & Terminalia sperba & $0.15 \pm 0.45$ \\
\hline Ulmaceae & Trema orientalis & $0.13 \pm 0.30$ \\
\hline
\end{tabular}

medium land-use intensity categories compared to study sites under high to very high land-use categories (Figure 5(a)). Bee species richness and abundance were significantly higher in low land-use intensity than in all the other land-use categories. Similarly, bee population density was on average significantly $(P<0.05)$ two to three times greater in study sites with low to medium land-use intensity gradients compared to study sites with high to very high land-use intensity gradients (Figure 5(b)).

3.4. Nest Density and Bee Attraction to Various Types of Habitats/Land-Uses. Few environmental factors (landuses/habitats) were observed to be significantly $(P<0.05)$ associated with high species richness and abundance of bees (Table 3). They were of high value for bees. Across study sites and sampling rounds, some habitats attracted a high number of bee species and individuals both during rainy and dry seasons: fallows, forest plantations, and woodlands. Count of nesting sites was conducted concurrently to bee surveys. Across study sites and sampling rounds, nest density (mean number of nests/0.5 ha transect/site) was significantly and positively related to bee species richness $\left(R^{2}=0.381, F_{(1,28)}=\right.$ 8.97, $P<0.001)$ and to bee abundance $\left(R^{2}=0.211, F_{(1,28)}\right.$ $=5.67, P<0.05)$. There was a variation in the density of nests per nesting type per land-use/habitat type (Table 4 ). 
TABLE 6: List of pollinator-dependent crops and nonpollinator crops grown in Uganda (the crop species are presented per dependency status, crop category, common names, and scientific names).

\begin{tabular}{|c|c|c|c|}
\hline Dependency status & Crop category & Common names & Scientific name \\
\hline Nonpollinator-dependent crop & Banana & Plantains & Musa sp. \\
\hline Nonpollinator-dependent crop & Cereal crops & Finger millet & 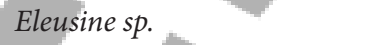 \\
\hline Nonpollinator-dependent crop & Cereal crops & Maize & Zea maize \\
\hline Nonpollinator-dependent crop & Cereal crops & Sorghum & Sorgum bicolor \\
\hline Nonpollinator-dependent crop & Cereal crops & Rice & Oryza sativa \\
\hline Nonpollinator-dependent crop & Cereal crops & Wheat & Triticum sp. \\
\hline Nonpollinator-dependent crop & Root/tuber crops & Sweet potatoes & Ipomoea batatus \\
\hline Nonpollinator-dependent crop & Root/tuber crops & Potatoes & Solanum tuberusum \\
\hline Nonpollinator-dependent crop & Root/tuber crops & Cassava & Manihot esculentum \\
\hline Pollinator-dependent crop & Pulse crops & & Phaseolus vulgarus \\
\hline Pollinator-dependent crop & Pulse crops & Field peas & Pisum arvense \\
\hline Pollinator-dependent crop & Pulse crops & Cowpeas & Vigna unguiculata \\
\hline Pollinator-dependent crop & Pulse crops & Greengram seeds & Vigna radiata \\
\hline Pollinator-dependent crop & Pulse crops & Peageon peas & Cajanus cajan \\
\hline Pollinator-dependent crop & Pulse crops & Bambaranut & Vigna subterranea \\
\hline Pollinator-dependent crop & Pulse crops & Groundnut & Arachis hypogea \\
\hline Pollinator-dependent crop & Industrial crops/edible oils & Soy beans & Glycine max \\
\hline Pollinator-dependent crop & Industrial crops/edible oils & Sim-Sim seeds & Sesamum indicum \\
\hline Pollinator-dependent crop & Industrial crops/edible oils & Sun-flower seeds & Helianthus annus \\
\hline Pollinator-dependent crop & Industrial crops/edible oils & Coffee beans & Coffea canephora/arabica \\
\hline Pollinator-dependent crop & Industrial crops/edible oils & Cotton seed & Gossypium sp. \\
\hline Pollinator-dependent crop & Industrial crops/edible oils & Tobacco seed & Nicotiana tabacum \\
\hline Pollinator-dependent crop & Industrial crops/edible oils & Tea & Camelia sinsensis \\
\hline Pollinator-dependent crop & Industrial crops/edible oils & Sugar & Sugar cane \\
\hline Pollinator-dependent crop & Industrial crops/edible oils & Cocoa & Theobroma cacao \\
\hline Pollinator-dependent crop & Industrial crops/edible oils & Coconut & Cocos nucifera \\
\hline Pollinator-dependent crop & Fruit crops & Avocado & Persea americana \\
\hline Pollinator-dependent crop & Fruit crops & Mangos & Mangifera indica \\
\hline Pollinator-dependent crop & Fruit crops & Orange and tangerine & Citrus myrtifolia/reticulata \\
\hline Pollinator-dependent crop & Fruit crops & Grapefruits & Citrus grandis \\
\hline Pollinator-dependent crop & Fruit crops & Passion fruits & Passiflora edulis \\
\hline Pollinator-dependent crop & Fruit crops & Papaw & Carica papaya \\
\hline Pollinator-dependent crop & Fruit crops & Guavas & Psidium guajava \\
\hline Pollinator-dependent crop & Fruit crops & Apples & Malus domestica \\
\hline Pollinator-dependent crop & Fruit crops & Jackfruit & Artocarpus heterophyllus \\
\hline Pollinator-dependent crop & Vegetable crops & Tomato fruits & Lycopersicon esculentum \\
\hline Pollinator-dependent crop & Vegetable crops & Eggplants & Solanum melongena \\
\hline Pollinator-dependent crop & Vegetable crops & Pepper fruits & Capsicum fruitescens \\
\hline Pollinator-dependent crop & Vegetable crops & Mustard seeds & Brassica alba \\
\hline Pollinator-dependent crop & Vegetable crops & Okra, Gumbo & Abelmoschus esculentus \\
\hline Pollinator-dependent crop & Vegetable crops & Pumpkin & Cucurbita maxima/moschata \\
\hline Pollinator-dependent crop & Vegetable crops & Squash & Cucurbitamixta \\
\hline Pollinator-dependent crop & Vegetable crops & Gourde & Lagenaria siceraria \\
\hline Pollinator-dependent crop & Vegetable crops & Watermelon & Citrullus lunatus \\
\hline Pollinator-dependent crop & Vegetable crops & Cucumber & Cucumis sativus \\
\hline Pollinator-dependent crop & Spices and condiments & Vanilla & Vanilla planifolia \\
\hline Pollinator-dependent crop & Medicinal plants & Moringa & Moringa oleifera \\
\hline
\end{tabular}


TABLE 7: List of common wild flowering plant species visited by bees during floral resources collection in the coffee-banana farming system of central Uganda. Species are arranged per family, life cycle type, and type of flower colour/shape. These are plant species met in blooming periods and that were observed being visited by different bees species during transect surveys.

\begin{tabular}{|c|c|c|c|}
\hline Family & Species & Lifecycle & Flower color/shape \\
\hline Mimosaceae & Acacia hockii De Wild & Tree & Yellow \\
\hline Mimosaceae & Acacia gerradii Benth & Tree & Dirty/white \\
\hline Mimosaceae & Acacia zanziberica & Shrub & Yellow \\
\hline Euphorbiaceae & Acalypha bipartita Muell. Arg. & Shrub & Green \\
\hline Euphorbiaeae & Acalypha ornata A.Rich. & Shrub & Red \\
\hline Acanthaceae & Acanthus pubescens Engl & Shrub & Pink \\
\hline Asteraceae & Acmella caulirhiza Delile & Herb & Yellow \\
\hline Asteraceae & Ageratum conyzoides $\mathrm{L}$. & Herb & White \\
\hline Mimosaceae & Albizzi grandibracteata Taub & Tree & Pale/green \\
\hline Mimosaceae & Albizzia glaberrima (Schumach. and Thonn.) Benth & Tree & White \\
\hline Mimosaceae & Albizzia adianthifolia (Schumach.) W.F. Wight & Tree & White \\
\hline Mimosaceae & Albizzia coriaria Oliv. & Tree & White \\
\hline Scrophulariaceae & Alectra sessiliflora (Vahl) Kuntze & Herb & Yellow \\
\hline Amaranthaceae & Amaranthus dubius Thell & Herb & Green \\
\hline Amaranthaceae & Amaranthus hybridus L.subsp.hybridus & Herb & Green \\
\hline Aristolochiaceae & Aristolochia elegans Mast. & Herb & Reddish/purple \\
\hline Asteraceae & Aspilia africana (Pers) C.D.Adams & Herb & Yellow \\
\hline Acanthaceae & Asystasia gangetica (L.) T.Andersson & Herb & White \\
\hline Acanthaceae & Asystasia mysorensis (Roth) T.Anderson & Herb & White \\
\hline Acanthaceae & Barleria spinisepale & Herb & Purple \\
\hline Asteraceae & Berkheya spekeana Oliv. & Herb & Yellow \\
\hline Asteraceae & Bidens pilosa $\mathrm{L}$. & Herb & White/yellow \\
\hline Oxalidaceae & Biophytum abyssinicum A.Rich. & Herb & Yellow \\
\hline Euphorbiaceae & Bridelia micrantha (Hochst) Baill & Tree & Greenish/yellow \\
\hline Caesalpiniaceae & Caesalpinia decapetala (Roth) Al & Shrub & Yellow \\
\hline Papilionaceae & Cajanus cajan (L.) Millsp & Shrub & Yellow \\
\hline Mimosaceae & Calliandra calothyrsus Meissner & Shrub & Red \\
\hline Myrtaceae & Callistemon lanceolatus DC. & Tree & Red \\
\hline Theaceae & Camellia sinensis (L.) O.Ktze. & Tree & White/cream \\
\hline Pailionaceae & Canavalia africana Dunn & Herb & Purple \\
\hline Pailionaceae & Canavalia virosa (Roxb.) Wight & Herb & Purple \\
\hline Solanaceae & Capsicum annum L. & Herb & Green \\
\hline Sapindaceae & Cardiospermum halicacabum L. & Herb & White \\
\hline Caesalpiniaceae & Cassia hirsuta L. & Herb & Yellow \\
\hline Caesalpiniaceae & Cassia kirkii Oliv. & Herb & Yellow \\
\hline Meliaceae & Cedrella odorata $\mathrm{L}$. & Tree & Yellow/greenish \\
\hline Rutaceae & Citrus aurantifolia Swingle & Tree & White \\
\hline Rutaceae & Citrus lemon (L.) Burm.f. & Tree & White \\
\hline Rutaceae & Citrus reticulata Blanco & Tree & White \\
\hline Rutaceae & Citrus sinensis (L.) Osbeck & Tree & White \\
\hline Capparaceae & Cleome gynandra (L.) Briq. & Herb & White \\
\hline Capparaceae & Cleome monophylla L. & Herb & Purple \\
\hline Verbenaceae & Clerodendrum myricoides (Hochct.) Vodke & Shrub & Blue \\
\hline Verbenaceae & Clerodendrum rotundifolium Oliv. & Herb & White \\
\hline Palmae & Cocos nucifera L. & Tree & Orange/yellow \\
\hline Commelinaceae & Commelina benghalensis $\mathrm{L}$. & Herb & Yellow \\
\hline Commelinaceae & Commelina africana $\mathrm{L}$. & Herb & Yellow \\
\hline Asteraceae & Crassocephalum montuosum (S. Moore) Milne-Redh. & Herb & Red \\
\hline Asteraceae & Crassocephalum vitellinum (Benth.) S. moore & Herb & Yellow \\
\hline
\end{tabular}


Psyche

TABLE 7: Continued.

\begin{tabular}{|c|c|c|c|}
\hline Family & Species & Lifecycle & Flower color/shape \\
\hline Papilionaceae & Crotalaria incana $\mathrm{L}$. & Herb & Yellow \\
\hline Papilionaceae & Crotalaria brevidens Benth.var. Intermedia (Kotschy) Polh. & Herb & Yellow \\
\hline Papilionaceae & Crotalaria laburnifolia $\mathrm{L}$. & Herb & Yellow \\
\hline Papilionaceae & Crotalaria natalica Meisn & Herb & Yellow \\
\hline Vitaceae & Cyphostemma adenocaule (A.Rich.) Willd. and Drummond & Herb & Red \\
\hline Papilionaceae & Desmodium Salicifolium (Poir.) DC. & Herb & Pink/purple \\
\hline Papilionaceae & Desmodium tortusum (Sw.) DC. & Herb & Pink \\
\hline Asteraceae & Dichrocephala integrifolia (L.f.) O.Ktze & Herb & Greenish/whitish \\
\hline Acanthaceae & Dyschoriste radicans Nees & Herb & Yellow \\
\hline Palmae & Elaeis huineensis Jacq & Tree & Yellow \\
\hline Asteraceae & Emilia javanica (Burm.f.) C.B. Rob. & Herb & Red \\
\hline Papilionaceae & Eriosema psoraleoides (Lam.) G.Don & Herb & Yellow \\
\hline Asteraceae & Erlangea cordifolia (Oliv) S. Moore & Herb & Purple \\
\hline Asteraceae & Erlangea tomentosa S. Moore & Herb & Light purple \\
\hline Asteraceae & Erlangea ugandensis S. Moore & Shurb & Blue \\
\hline Cruciferae & Erucastrum arabicum Fisch and Mey & Herb & Yellow \\
\hline Papilionaceae & Erythrina abyssinica DC & Tree & Red \\
\hline Myrtaceae & Eucalyptus grandis Marden & Tree & Pale \\
\hline Myrtaceae & Eucalyptus camaldulensis & Tree & Cream \\
\hline Euphorbiaceae & Euphorbia heterophylla L. & Herb & Cream \\
\hline Euphorbiaceae & Euphorbia hirta L. & Herb & Green/purple \\
\hline Asteraceae & Galisonga parviflora Cav. & Herb & White/yellow \\
\hline Papilionaceae & Gliricidia sepium (Jacq.) $\mathrm{V}$ & Tree & NIL \\
\hline Papilionaceae & Glycine wightii (Wight and Arn.) & Herb & Pale/grey \\
\hline Asteraceae & Guizotia scabra (Vis.) Chiov. & Herb & Yellow \\
\hline Asteraceae & Helianthus annua $\mathrm{L}$. & Herb & Yellow \\
\hline Convulvulaceae & Hewittia sublobata (L.f.) $\mathrm{O}$ & Herb & Yellow \\
\hline Malvaceae & Hibiscus surrantensis L. & Herb & Yellow \\
\hline Malvaceae & Hibiscus diversifolius Jacq & Shrub & Yellow \\
\hline Malvaceae & Hibiscus ludwigii Eckl. and Zeyh & Shrub & Yellow \\
\hline Lamiaceae & Hoslundia opposita Vahl & Herb & Yellowish \\
\hline Papilionaceae & Indiofera spicata Forssk. & Herb & Red \\
\hline Convulvulaceae & Ipomoea cairica (L.) Sweet & Herb & Purple \\
\hline Convulvulaceae & Ipomoea hederifolia $\mathrm{L}$. & Herb & Red \\
\hline Convulvulaceae & Ipomoea obscura (L.) Ker-Gawl & Herb & Yellow \\
\hline Convulvulaceae & Ipomoea purpurea (L.) Roth & Herb & Purple \\
\hline Convulvulaceae & Ipomoea wightii (Wall.) Choisy & Herb & Purple \\
\hline Acanthaceae & Justicia flava (Forsk) Vahl & Herb & Yellow \\
\hline Acanthaceae & Justicia heterocarpa T.Andersson & Herb & Pink \\
\hline Cyperaceae & Kyllinga bulbosa P.Beauv. & Sedge & White \\
\hline Verbenaceae & Lantana camara $\mathrm{L}$. & Shrub & Pink \\
\hline Verbenaceae & Lantana trifolia $\mathrm{L}$. & Shrub & Light purple \\
\hline Lamiaceae & Leonotis nepetifolia (L.) Ait.f. & Herb & Red \\
\hline Mimosaceae & Leucaena leucocephala (Lam.) De Wit & Tree & Red \\
\hline Lamiaceae & Leucas deflexa Hook.f. & Herb & White \\
\hline Verbenaceae & Lippia abyssinica (Otto and Diebr) Cuf. & Herb & White/yellow \\
\hline Lamiaceae & Luecas martinicensis (Jacq) Ait.f. & Herb & White \\
\hline Myrsinaceae & Maesa lanceolata Forsk & Tree & Green \\
\hline Anacardiaceae & Mangifera indica $\mathrm{L}$. & Tree & Cream \\
\hline Bignoniaceae & Markhamia lutea K.Schum. & Tree & Yellow \\
\hline
\end{tabular}




\begin{tabular}{|c|c|c|c|}
\hline Family & Species & Lifecycle & Flower color/shape \\
\hline Asteraceae & Melanthera scandens (Schumach and Thonn) Roberty & Herb & Yellow \\
\hline Asteraceae & Microglossa pyrifolia (Lam.) O.Ktze. & Shurb & Pale/yellow \\
\hline Moraceae & Milicia excelsa (Welw.) C.C. Berg. & Tree & Greenish \\
\hline Mimosaceae & Mimosa pigra L. & Shrub & Pink \\
\hline Mimosaceae & Mimosa pudica L. & Herb & Purple \\
\hline Rubiaceae & Mitracarpus villosus (S.W.) DC & Herb & White \\
\hline Cucurbitaceae & Momordica foetida Schumach. & & Yellow \\
\hline Moringaceae & Moringa oleifera Lam. & Tree & White/cream \\
\hline Moraceae & Morus alba L. & Tree & Nil \\
\hline Musaceae & Musa paradisiaca $\mathrm{L}$. & Tree & Red/brown/purple \\
\hline Musaceae & Musa sapienthum & Tree & Red/brown/purple \\
\hline Lamiaceae & Ocimum gratissimum ( L.) O.Suave & Herb & White \\
\hline Lamiaceae & Ocimum gratissimum var.rutshuruensis De Wild & Herb & White \\
\hline Lamiaceae & Ocimum suave Willd. & Herb & White \\
\hline Oxalidaceae & Oxalis corniculata $\mathrm{L}$. & Herb & Yellow \\
\hline Oxalidaceae & Oxalis latifolia $\mathrm{L}$. & Herb & Pink \\
\hline Polygonaceae & Oxygonum snuatum (Meisn.) Dammer & Herb & Pale/pink \\
\hline Passifloraceae & Passiflora edulis Sims & Tree & Purple \\
\hline Lauraceae & Persea americana Mill. & Tree & Cream \\
\hline Solanaceae & Physalis peruviana L. & Herb & Yellow \\
\hline Phytolacaceae & Phytolacca dodecandra L'Herit & Herb & Greenish/white \\
\hline Lamiaceae & Plastostoma africanum P. Beauv. & Herb & White \\
\hline Lamiaceae & Plectranthus barbatus And & Herb & Purple \\
\hline Rubiaceae & Pnetas parvifolia & Herb & Red/marron \\
\hline Polygalaceae & Polygala pygmaea Gurke & Herb & Yellow \\
\hline Polygonaceae & Polygonum setosulum A.Rich. & Herb & Pink \\
\hline Papilionaceae & Pseudarthria hookeri Wight and Arn. & Herb & Pink \\
\hline Myrtaceae & Psidium guajava $\mathrm{L}$. & Tree & White \\
\hline Euphorbiceae & Ricinus communis L. & Tree & Yellowish \\
\hline Polygonaceae & Rumex abyssinicus Jacq & Herb & Greenish \\
\hline Polygonaceae & Rumex bequaertii De Wild & Herb & Greenish \\
\hline Asteraceae & Senecio discifolius Oliv. & Herb & Yellow \\
\hline Caesalpiniaceae & Senna didimobotrya $\mathrm{L}$. & Shrub & Yellow \\
\hline Pedaliaceae & Sesamum angolense Welw & Herb & Purple \\
\hline Malvaceae & Sida acuta Burm.f. & Herb & Cream/pale \\
\hline Malvaceae & Sida cordifolia L. & Herb & Yellow \\
\hline Malvaceae & Sida cuneifolia Roxb. & Herb & Yellow \\
\hline Malvaceae & Sida rhombifolia L. & Herb & Whitish/yellowish \\
\hline Asteraceae & Siegesbeckia abyssinica (Ch. Bip.) Oliv. and Hiern & Herb & Yellow \\
\hline Asteraceae & Siegesbeckia orientalis L. & Herb & Yellow \\
\hline Solanaceae & Solanum nigrum L. & Herb & White/yellow \\
\hline Solanaceae & Solanum aculeastrum Dunal & Shrub & White \\
\hline Solanaceae & Solanum anguivii Lam. & Herb & White \\
\hline Solanaceae & Solanum florulentum Bitt. & Herb & White \\
\hline Solanaceae & Solanum incanum L. & Herb & Purple \\
\hline Solanaceae & Solanum macrocarpon L. & Herb & Purple \\
\hline Solanaceae & Solanum mauritianum Scop & Shrub & Purple \\
\hline Bignoniaceae & Spathodea nilotica Seem & Herb & Red \\
\hline Rubiaceae & Spermacoce princeae (K. Schum.) & Herb & White \\
\hline Verbenaceae & Stachytarpheta cayennensis (Rich.) Vahl & Herb & Blue \\
\hline
\end{tabular}


TABLE 7: Continued.

\begin{tabular}{llll}
\hline Family & Species & Lifecycle & Flower color/shape \\
\hline Papilionaceae & Tephrosia rhodesia Bak.f. & Herb & Purple \\
Papilionaceae & Tephrosia vogelii Hook.f. & Shrub & Purple/white \\
Apocynaceae & Thevetia pereviana (Pob) K.Schum. & Shrub & Yellow \\
Acanthaceae & Thumbergia holstii & Herb & Purple \\
Acanthaceae & Thunbergia alata Sims & Herb & Yellow \\
Asteraceae & Tridax procumbens & Herb & Yellow \\
Tiliaceae & Triumfetta tomenosa Boj. & Shrub & Yellow \\
Tiliaceae & Triumfetta rhomboidea Jacq & Herb & Yellow \\
Tiliaceae & Triumfetta trichocarpa A.Rich. & Herb & Cream \\
Typhaceae & Typha domingensis Pers & Sedge & Brown \\
Malvaceae & Urena lobata L. & Herb & Pink \\
Asteraceae & Vernonia cinerea (L.) Less. & Herb & Purple \\
Asteraceae & Vernonia amygdalina Del. & Tree & White/cream \\
Asteraceae & Vernonia auriculifera Hiern & Tree & Purple \\
Asteraceae & Vernonia auriculifera Hiern & Tree & Cream/white \\
Asteraceae & Vernonia campanea S. moore & Herb & Purple \\
Asteraceae & Vernonia kirungei & Shrub & Purple \\
Asteraceae & Vernonia lasiopus O.Haffm. & Herb & Purple \\
Papilionaceae & Vigna vexillata (L.) A.Rich. & Herb & Purple \\
\hline & & &
\end{tabular}

Different bee species used a variety of tree species (fruit and agroforestry tree species) as nest trees (Table 5). In other words, apart from establishing nests in various semi-natural habitats surrounding fields, some bee species (e.g., eusocial bees) managed to establish their nests in hallows of living trees, meaning that one should know these tree species and maintain them in the farm-landscape to increase nesting sites opportunities of good pollinators living within agricultural matrices.

\section{Discussion}

4.1. Effects of Climatic Factors on Bee Communities. Results from this study indicated that bee species richness and abundance were affected by climatic factors. In fact, species richness and abundance of bees were correlated with 10 years average temperature, as well as with temperature in the current year and two years prior to the study. Thus, temperature was found to be a very good and significant predictor of bee species in previous and current years. In climatic regions with strong wet-dry seasonality and low cold-hot seasonality, the main factor influencing occurrence, temporal distribution of different foraging bee species is temperature [18]. Even when there is a great variability in humidity and solar radiation (light intensity) along the year and the day, their influences on bee foraging seem to be small at the regional level although the influence at the microlevel may be higher. Temperature plays therefore a crucial role in occurrence and emergence of different adult bee species. Temperature is a key determinant of phenology of insect pollinated plants in natural and agricultural landscapes. Temperature is expected to be of primary importance in regulating phenology of pollinators, with other factors playing a secondary role $[32,54,55]$. The temperature seems to be responsible for adult appearance of bees in the environment, and this strong dependence may be expected because the average daily temperatures matters in the foraging behavior of many bee species. Multiyears monitoring data showed that climatic fluctuations are primarily responsible for the interannual variability in appearance phenology of bee species belonging to several functional groups [18].

While for some bee species (such as Apis mellifera), occurrence (presence/absence) may be related to increasing temperature, for most bee species, some factors (microhabitats, farming practices, and land-use intensity) may influence the occurrence/appearance and phenology. Although bee species richness and abundance were observed to be negatively and significantly correlated to maximum temperature and minimum temperature one to two years prior to the study, at the moment there exists no clear explanation for such pattern. The fact that the species richness and abundance of bees were strongly correlated with mean annual temperature in the previous years than in current years indicated potential vulnerability of local/native bee species to global environment and climatic changes [18]. Consequently, various bee species may be at risk of disappearance (extinction) in face of future climate change and variability in central Uganda. Such patterns were previously predicted for other pollinating species such as butterflies, flies, and beetles [18] in central Uganda.

Strong associations between previous (not current) year precipitation and the abundance/richness of bees were found in this study.

These results are consistent with the observation that previous year precipitation cues bee emergence in agricultural regions of Sub-Saharan Africa including Uganda [18]. 
TABLE 8: List of bee species collected in coffee-banana agroforestry systems in central Uganda in 2006.

\begin{tabular}{|c|c|c|c|}
\hline Family & Species & Family & Species \\
\hline Andrenidae & Andrena africana (Friese, 1909) & Halictidae & Lasioglossum somereni (Cockerell, 1945) \\
\hline Andrenidae & Andrena notophila (Cockerell) & Halictidae & Lasioglossum stellatifrons (Cockerell, 1945) \\
\hline Andrenidae & Melitturga penrithorum (Eardley, 1991) & Halictidae & Lasioglossum trichardti (Cockerell) \\
\hline Andrenidae & Meliturgula braunsi (Friese, 1903) & Halictidae & Lasioglossum ugandicum (Cockerell, 1937) \\
\hline Andrenidae & Meliturgula eardleyana (Patiny, 2000) & Halictidae & Lasioglossum zonaturum (Cockerell) \\
\hline Andrenidae & Meliturgula flavida (Friese, 1913) & Halictidae & Lassioglossum simulator (Cockerell, 1935) \\
\hline Andrenidae & Meliturgula rozeni (Eardley, 1991) & Halictidae & Lipotriches ablusa (Cockerell) \\
\hline Andrenidae & Meliturgula scriptifrons (Walker, 1871) & Halictidae & Lipotriches amatha (Cockerell, 1935) \\
\hline Andrenidae & Meliturgula wilmattae (Cockerell, 1932) & Halictidae & Lipotriches angustifrons (Cockerell) \\
\hline Apidae & Afromelecta bicuspis (Stadelmann, 1898) & Halictidae & Lipotriches armatipes (Friese, 1930) \\
\hline Apidae & Allodape armatipes (Friese, 1924) & Halictidae & Lipotriches aureotecta (Cockerell, 1931) \\
\hline Apidae & Allodape brachycephala (Michener, 1971) & Halictidae & Lipotriches aurifrons (Smith, 1853) \\
\hline Apidae & Allodape ceratinoides (Gribodo, 1884) & Halictidae & Lipotriches brevipennis (Friese, 1915) \\
\hline Apidae & Allodape collaris (Vachal, 1903) & Halictidae & Lipotriches clavata (Cockerell) \\
\hline Apidae & Allodape exoloma (Strand, 1915) & Halictidae & Lipotriches collaris (Vachal) \\
\hline Apidae & Allodape friesei (Strand, 1915) & Halictidae & Lipotriches cubitalis (Vachal) \\
\hline Apidae & Allodape interrupta (Vachal, 1903) & Halictidae & Lipotriches dentipes (Friese, 1930) \\
\hline Apidae & Allodape macula (Strand, 1912) & Halictidae & Lipotriches digitata (Friese, 1909) \\
\hline Apidae & Allodape microsticta (Cockerell, 1934) & Halictidae & Lipotriches ethioparca (Cockerell, 1935) \\
\hline Apidae & Allodape punctata (Lepeletier and Audinet-Serville, 1825) & Halictidae & Lipotriches flavitarsis (Friese) \\
\hline Apidae & Allodape quadrilineata (Cameron, 1905) & Halictidae & Lipotriches friesei (Magretti, 1899) \\
\hline Apidae & Allodape rufogastra (Lepeletier and $\mathrm{Au}$ & Halictidae & Lipotriches gratiosa (Strand) \\
\hline Apidae & Allodape tridentipes (Cockerell, 1933) & Halictidae & Lipotriches guluensis (Cockerell) \\
\hline Apidae & Allodapula acutigera (Cockerell, 1936) & Halictidae & Lipotriches hirsutula (Cockerell) \\
\hline Apidae & Allodapula hessei (Michener) & Halictidae & Lipotriches inaequalis (Cockerell) \\
\hline Apidae & Allodapula jucunda (Smith, 1879) & Halictidae & Lipotriches kampalana (Cockerell, 1935) \\
\hline Apidae & Allodapula maculithorax (Michener, 1971) & Halictidae & Lipotriches longipes (Strand) \\
\hline Apidae & Allodapula melanopus (Cameron, 1905) & Halictidae & Lipotriches macropus (Friese) \\
\hline Apidae & Allodapula monticola (Cockerell, 1933) & Halictidae & Lipotriches meadewaldoi (Brauns, 1912) \\
\hline Apidae & Allodapula palliceps (Friese, 1924) & Halictidae & Lipotriches natalensis (Cockerell, 1916) \\
\hline Apidae & Allodapula rozeni (Michener, 1975) & Halictidae & Lipotriches notabilis (Schletterer) \\
\hline Apidae & Allodapula variegata (Smith, 1854) & Halictidae & Lipotriches nubecula (Smith, 1875) \\
\hline Apidae & Amegilla acraensis (Fabricius, 1793) & Halictidae & Lipotriches oberthurella (Saussure) \\
\hline Apidae & Amegilla africana (Friese, 1905) & Halictidae & Lipotriches orientalis (Friese, 1909) \\
\hline Apidae & Amegilla albocaudata (Dours, 1869) & Halictidae & Lipotriches patellifera (Westwood, 1875) \\
\hline Apidae & Amegilla atrocincta (Lepeletier, 1841) & Halictidae & Lipotriches picardi (Gribodo) \\
\hline Apidae & Amegilla bothai (Friese) & Halictidae & Lipotriches reichardia (Strand, 1911) \\
\hline Apidae & Amegilla calens (Lepeletier, 1841) & Halictidae & Lipotriches rubella (Smith) \\
\hline Apidae & Amegilla capensis (Friese) & Halictidae & Lipoiriches rufipes (Smith, 1875) \\
\hline Apidae & Amegilla eritrina (Friese, 1915) & Halictidae & Lipotriches ruwenzorica (Cockerell, 1935) \\
\hline Apidae & Amegilla fallax (Smith, 1879) & Halictidae & Lipotriches sessensis (Cockerell) \\
\hline Apidae & Amegilla madecassa (Saussure) & Halictidae & Lipotriches sjoestedti (Friese, 1909) \\
\hline Apidae & Amegilla mimadvena (Cockerell, 1916) & Halictidae & Lipotriches speculina (Cockerell, 1942) \\
\hline Apidae & Amegilla natalensis (Friese, 1922) & Halictidae & Lipotriches spinulifera (Cockerell) \\
\hline Apidae & Amegilla nila (Eardley, 1994) & Halictidae & Lipotriches tanganyicensis (Strand, 1913) \\
\hline Apidae & Amegilla niveata (Friese, 1905) & Halictidae & Lipotriches viciniformis (Cockerell, 1939) \\
\hline Apidae & Amegilla nubica (Lepeletier, 1841) & Halictidae & Lipotriches vulpina (Gerstäcker, 1857) \\
\hline
\end{tabular}


TABLE 8: Continued.

\begin{tabular}{|c|c|c|c|}
\hline Family & Species & Family & Species \\
\hline Apidae & Amegilla obscuriceps (Friese, 1905) & Halictidae & Lipotriches welwitschi (Cockerell, 1908) \\
\hline Apidae & Amegilla penicula (Eardley, 1994) & Halictidae & Lipotriches whitfieldi (Cockerell, 1942) \\
\hline Apidae & Amegilla punctifrons (Walker, 1871) & Halictidae & Nomia amabilis (Cockerell, 1908) \\
\hline Apidae & Amegilla rapida (Smith, 1879) & Halictidae & Nomia atripes (Friese, 1909) \\
\hline Apidae & Amegilla regalis (Cockerell, 1946) & Halictidae & Nomia bouyssoui (Vachal, 1903) \\
\hline Apidae & Amegilla rufipes (Lepeletier, 1841) & Halictidae & Nomia brevipes (Friese, 1914) \\
\hline Apidae & Amegilla sierra (Eardley, 1994) & Halictidae & Nomia candida (Smith, 1875) \\
\hline Apidae & Amegilla somalica (Magretti) & Halictidae & Nomia chandleri (Ashmead, 1899) \\
\hline Apidae & Amegilla terminata (Smith, 1879) & Halictidae & Nomia clavicauda (Cockerell) \\
\hline Apidae & Anthophora vestita (Smith, 1854) & Halictidae & Nomia elephas (Strand, 1911) \\
\hline Apidae & Anthophora armata (Friese, 1905) & Halictidae & Nomia ethiopica (Pauly, 2000) \\
\hline Apidae & Anthophora basalis (Smith) & Halictidae & Nomia felina (Cockerell) \\
\hline Apidae & Anthophora braunsiana (Friese, 1905) & Halictidae & Nomia forbesii (W. F. Kirby, 1900) \\
\hline Apidae & Anthophora diversipes (Friese, 1922) & Halictidae & Nomia garambensis (Pauly, 2000) \\
\hline Apidae & Anthophora glaucopis (Friese, 1905) & Halictidae & Nomia granulata (Vachal, 1903) \\
\hline Apidae & Anthophora rufolanata (Dours) & Halictidae & Nomia lutea (Warncke, 1976) \\
\hline Apidae & Anthophora rufovestita (Cockerell) & Halictidae & Nomia maculata (Friese) \\
\hline Apidae & Anthophora schultzei (Friese, 1909) & Halictidae & Nomia marginata (Pauly, 1990) \\
\hline Apidae & Anthophora strucki (Eardley and Brooks, 1989) & Halictidae & Nomia nigrociliata (Cockerell, 1932) \\
\hline Apidae & Anthophora wartmanni (Friese, 1905) & Halictidae & Nomia politula (Cockerell) \\
\hline Apidae & Anthophora xanthostoma (Cockerell, 1932) & Halictidae & Nomia postscutellaris (Strand, 1914) \\
\hline Apidae & Apis mellifera adansonii (Linnaeus, 1758) & Halictidae & Nomia pretoriensis (Cockerell, 1946) \\
\hline Apidae & Apis mellifera scutellata (Latreille, 1804) & Halictidae & Nomia rozeni (Pauly, 2000) \\
\hline Apidae & Braunsapis facialis (Gerstäcker, 1857) & Halictidae & Nomia rufosuffusa (Cockerell, 1935) \\
\hline Apidae & Braunsapis albipennis (Friese, 1909) & Halictidae & Nomia senticosa (Vachal, 1897) \\
\hline Apidae & Braunsapis albitarsis (Friese, 1924) & Halictidae & Nomia somalica (Friese, 1908) \\
\hline Apidae & Braunsapis angolensis (Cockerell, 1933) & Halictidae & Nomia stageri (Pauly, 2000) \\
\hline Apidae & Braunsapis bouyssoui (Vachal, 1903) & Halictidae & Nomia theryi (Gribodo, 1894) \\
\hline Apidae & Braunsapis flavitarsis (Gerstaecker) & Halictidae & Nomia viridicincta (Meade-Waldo) \\
\hline Apidae & Braunsapis foveata (Smith, 1854) & Halictidae & Nomia whiteana (Cameron, 1905) \\
\hline Apidae & Braunsapis gorillarum (Cockerell, 1936) & Halictidae & Nomia zonaria (Walker, 1871) \\
\hline Apidae & Braunsapis leptozonia (Vachal) & Halictidae & Nomioides micheneri Pesenko and Pauly \\
\hline Apidae & Braunsapis minutula (Friese, 1914) & Halictidae & Patellapis aberdarica (Cockerell, 1945) \\
\hline Apidae & Braunsapis natalica (Michener, 1970) & Halictidae & Patellapis albofasciata (Smith, 1879) \\
\hline Apidae & Braunsapis neavei (Vachal, 1910) & Halictidae & Patellapis benoiti (Pauly) \\
\hline Apidae & Braunsapis rhodesi (Cockerell, 1936) & Halictidae & Patellapis bilineata (Friese) \\
\hline Apidae & Braunsapis strandi (Masi, 1930) & Halictidae & Patellapis communis (Smith, 1879) \\
\hline Apidae & Braunsapis vitrea (Vachal, 1903) & Halictidae & Patellapis disposita (Cameron, 1905) \\
\hline Apidae & Ceratina aliceae (Cockerell, 1937) & Halictidae & Patellapis flavofasciata (Friese, 1915) \\
\hline Apidae & Ceratina armata (Smith, 1854) & Halictidae & Patellapis flavorufa (Cockerell, 1937) \\
\hline Apidae & Ceratina braunsi (Eardley and Daly, 2007) & Halictidae & Patellapis glabra (Pauly, 1989) \\
\hline Apidae & Ceratina excavata (Cockerell) & Halictidae & Patellapis gowdeyi (Cockerell, 1937) \\
\hline Apidae & Ceratina labrosa (Friese, 1905) & Halictidae & Patellapis hargreavesi (Cockerell) \\
\hline Apidae & Ceratina lineola (Vachal, 1903) & Halictidae & Patellapis harunganae (Pauly, 1989) \\
\hline Apidae & Ceratina lunata (Friese, 1905) & Halictidae & Patellapis kivuensis (Pauly, 1989) \\
\hline Apidae & Ceratina minuta (Friese, 1905) & Halictidae & Patellapis macrozonia (Cockerell) \\
\hline Apidae & Ceratina moerenhouti (Vachal) & Halictidae & Patellapis minima (Friese, 1909) \\
\hline
\end{tabular}


TABLE 8: Continued.

\begin{tabular}{|c|c|c|c|}
\hline Family & Species & Family & Species \\
\hline Apidae & Ceratina nasalis (Friese, 1905) & Halictidae & Patellapis minutior (Friese, 1909) \\
\hline Apidae & Ceratina nigriceps (Friese, 1905) & Halictidae & Patellapis mosselina (Cockerell) \\
\hline Apidae & Ceratina nilotica (Cockerell, 1937) & Halictidae & Patellapis neavei (Cockerell, 1946) \\
\hline Apidae & Ceratina paulyi (Daly, 1988) & Halictidae & Patellapis nomioides (Friese, 1909) \\
\hline Apidae & Ceratina penicillata (Friese, 1905) & Halictidae & Patellapis obscurescens (Cockerell) \\
\hline Apidae & Ceratina rufigastra (Cockerell, 1937) & Halictidae & Patellapis partita (Cockerell, 1933) \\
\hline Apidae & Ceratina ruwenzorica (Cockerell) & Halictidae & Patellapis patriciformis (Cockerell, 1933) \\
\hline Apidae & Ceratina speculifrons (Cockerell, 1920) & Halictidae & Patellapis perineti (Benoist, 1954) \\
\hline Apidae & Ceratina tanganyicensis (Strand, 1911) & Halictidae & Patellapis perpansa (Cockerell, 1933) \\
\hline Apidae & Ceratina viridifrons (Cockerell, 1934) & Halictidae & Patellapis pondoensis (Cockerell) \\
\hline Apidae & Ceratina viridis (Guérin-Méneville, 1844) & Halictidae & Patellapis retigera (Cockerell) \\
\hline Apidae & Ceratina whiteheadi (Eardley and Daly, 2007) & Halictidae & Patellapis ruwensorensis (Strand, 1911) \\
\hline Apidae & Cleptotrigona cubiceps (Friese, 1912) & Halictidae & Patellapis schultzei (Friese, 1909) \\
\hline Apidae & Compsomelissa nigrinervis (Cameron, 1905) & Halictidae & Patellapis spinulosa (Cockerell) \\
\hline Apidae & Compsomelissa nigrinervis (Cameron, 1905) & Halictidae & Patellapis terminalis (Smith, 1853) \\
\hline Apidae & Ctenoplectra albolimbata (Magretti) & Halictidae & Patellapis tshibindica (Cockerell) \\
\hline Apidae & Ctenoplectra antinorii (Gribodo, 1884) & Halictidae & Patellapis vittata (Smith, 1853) \\
\hline Apidae & Ctenoplectra armata (Magretti, 1895) & Halictidae & Pseudapis aliceae (Cockerell, 1935) \\
\hline Apidae & Ctenoplectra polita (Strand, 1912) & Halictidae & Pseudapis anomala (W. F. Kirby, 1900) \\
\hline Apidae & Ctenoplectra terminalis (Smith, 1879) & Halictidae & Pseudapis anthidioides (Gerstäcker, 1857) \\
\hline Apidae & Ctenoplectra ugandica (Cockerell, 1944) & Halictidae & Pseudapis armata (Olivier, 1812) \\
\hline Apidae & Ctenoplectrina politula (Cockerell, 1930) & Halictidae & Pseudapis flavicarpa (Vachal) \\
\hline Apidae & Dactylurina schmidti (Stadelmann, 1895) & Halictidae & Pseudapis kenyensis (Pauly, 1990) \\
\hline Apidae & Dactylurina staudingeri (Gribodo) & Halictidae & Pseudapis patellata (Magretti, 1884) \\
\hline Apidae & Epeolus amabilis (Gerstäcker, 1869) & Halictidae & Pseudapis rhodocantha (Cockerell) \\
\hline Apidae & Epeolus corniculatus (Bischoff) & Halictidae & Pseudapis rugiventris (Friese, 1930) \\
\hline Apidae & Epeolus friesei (Brauns, 1903) & Halictidae & Pseudapis schubotzi (Strand) \\
\hline Apidae & Epeolus natalensis (Smith, 1879) & Halictidae & Seladonia africana (Friese) \\
\hline Apidae & Hypotrigona gribodoi (Magretti, 1884) & Halictidae & Seladonia jucundus (Smith) \\
\hline Apidae & Liotrigona bottegoi (Magretti, 1895) & Halictidae & Seladonia jucundus (Smith, 1853) \\
\hline Apidae & Macrogalea candida (Smith, 1879) & Halictidae & Seladonia valligensis (Cockerell, 1937) \\
\hline Apidae & Meliponula bocandei (Spinola, 1853) & Halictidae & Spatunomia filifera (Cockerell) \\
\hline Apidae & Meliponula ferruginea (Lepeletier, 1836) & Halictidae & Sphecodes abyssinicus (Sichel) \\
\hline Apidae & Meliponula lendliana (Friese, 1900) & Halictidae & Sphecodes braunsi (Blüthgen) \\
\hline Apidae & Meliponula nebulata (Smith, 1854) & Halictidae & Sphecodes centralis (Cockerell) \\
\hline Apidae & Nomada africana (Friese, 1911) & Halictidae & Sphecodes dilutus (Cockerell) \\
\hline Apidae & Nomada aurantifascia (Eardley and Schwarz, 1991) & Halictidae & Sphecodes fimbriatus (Blüthgen) \\
\hline Apidae & Nomada eximia (Eardley and Schwarz, 1991) & Halictidae & Sphecodes hagensi (Ritsema) \\
\hline Apidae & Nomada gigas (Friese, 1905) & Halictidae & Sphecodes luteiventris (Friese) \\
\hline Apidae & Nomada whiteheadi (Eardley and Schwarz, 1991) & Halictidae & Sphecodes punctatus (Sichel, 1865) \\
\hline Apidae & Pachymelus abessinicus (Friese, 1913) & Halictidae & $\begin{array}{l}\text { Sphecodes punctiscutum (Eardley and } \\
\text { Urban) }\end{array}$ \\
\hline Apidae & Pachymelus bettoni (Cockerell) & Halictidae & Sphecodes ugandae (Blüthgen, 1928) \\
\hline Apidae & Pachymelus ciliatus (Friese, 1922) & Halictidae & Sphecodes woodi (Cockerell) \\
\hline Apidae & Pachymelus claviger (Benoist, 1962) & Halictidae & Thrinchostoma bequaerti (Blüthgen) \\
\hline
\end{tabular}


TABLE 8: Continued.

\begin{tabular}{|c|c|c|c|}
\hline Family & Species & Family & Species \\
\hline Apidae & Pachymelus conspicuus (Smith, 1879) & Halictidae & Thrinchostoma emini (Blüthgen, 1930) \\
\hline Apidae & Pachymelus festivus (Dours, 1869) & Halictidae & Thrinchostoma mwangai (Blüthgen) \\
\hline Apidae & Pachymelus reichardti (Stadelmann, 1898) & Halictidae & Thrinchostoma sjoestedti (Friese, 1909) \\
\hline Apidae & Pasites appletoni (Cockerell, 1910) & Halictidae & Thrinchostoma torridum (Smith) \\
\hline Apidae & Pasites barkeri (Cockerell, 1919) & Halictidae & Thrinchostoma ugandae (Blüthgen, 1930) \\
\hline Apidae & Pasites braunsi (Bischoff, 1923) & Halictidae & Thrinchostoma umtaliellus (Cockerell, 1937) \\
\hline Apidae & Pasites carnifex (Gerstäcker, 1869) & Halictidae & Thrinchostoma wissmanni (Blüthgen, 1930) \\
\hline Apidae & Pasites dichroa (Smith, 1854) & Halictidae & Systropha ugandensis (Cockerell) \\
\hline Apidae & Pasites friesei (Cockerell, 1910) & Megachilidae & Afranthidium braunsi (Friese, 1904) \\
\hline Apidae & Pasites humecta (Eardley, 1997) & Megachilidae & Afranthidium junodi (Friese, 1904) \\
\hline Apidae & Pasites jenseni (Friese, 1915) & Megachilidae & Afranthidium sjoestedti (Friese, 1909) \\
\hline Apidae & Pasites jonesi (Cockerell, 1921) & Megachilidae & Afranthidium tanganyicola (Strand, 1911) \\
\hline Apidae & Pasites rotundiceps (Bischoff, 1923) & Megachilidae & Afroheriades larvatus (Friese, 1909) \\
\hline Apidae & Pasites rufipes (Friese, 1915) & Megachilidae & Afroheriades reicherti (Brauns, 1929) \\
\hline Apidae & Pasites somalicus (Eardley, 1997) & Megachilidae & Anthidiellum bipectinatum (Pasteels, 1984) \\
\hline Apidae & Plebeina hildebrandti (Friese, 1900) & Megachilidae & Anthidiellum eritrinum (Friese, 1915) \\
\hline Apidae & Sphecodopsis aculeata (Friese, 1922) & Megachilidae & Anthidiellum rubellum (Friese, 1917) \\
\hline Apidae & Sphecodopsis capensis (Friese, 1915) & Megachilidae & Anthidium abjunctum (Cockerell, 1936) \\
\hline Apidae & Sphecodopsis capicola (Strand, 1911) & Megachilidae & Anthidium basale (Pasteels, 1984) \\
\hline Apidae & Sphecodopsis minutissima (Cockerell, 1933) & Megachilidae & Anthidium cordiforme (Friese, 1922) \\
\hline Apidae & Sphecodopsis vespericena (Eardley, 1997) & Megachilidae & Anthidium niveocinctum (Gerstäcker, 1857) \\
\hline Apidae & Tetralonia boharti (Eardley, 1989). & Megachilidae & Anthidium pontis (Cockerell, 1933) \\
\hline Apidae & Tetralonia caudata (Friese, 1905) & Megachilidae & Anthidium severini (Vachal, 1903) \\
\hline Apidae & Tetralonia macrognatha (Gerstäcker, 18 & Megachilidae & Coelioxys aurifrons (Smith) \\
\hline Apidae & Tetralonia obscuriceps (Friese, 1916) & Megachilidae & Coelioxys caffra (Friese) \\
\hline Apidae & Tetralonia penicillata (Friese, 1905) & Megachilidae & Coelioxys cherenensis (Friese) \\
\hline Apidae & Tetralonia ruficollis (Friese, 1911) & Megachilidae & Coelioxys foveolata (Smith) \\
\hline Apidae & Tetralonia trichardti (Cockerell, 1933) & Megachilidae & Coelioxys nasuta (Friese) \\
\hline Apidae & Tetraloniella apicalis (Friese, 1905) & Megachilidae & Coelioxys natalensis (Cockerell, 1920) \\
\hline Apidae & Tetraloniella aurantiflava (Eardley, 1989) & Megachilidae & Coelioxys odin (Strand, 1912) \\
\hline Apidae & Tetraloniella braunsiana (Friese, 1905) & Megachilidae & Coelioxys recusata (Schulz) \\
\hline Apidae & Tetraloniella brevikeraia (Eardley, 1989) & Megachilidae & Coelioxys torrida (Smith) \\
\hline Apidae & Tetraloniella capensis (Lepeletier, 1841) & Megachilidae & Coelioxys ultima (Pasteels) \\
\hline Apidae & Tetraloniella elsei (Eardley, 1989) & Megachilidae & Coelioxys verticalis (Smith, 1854) \\
\hline Apidae & Tetraloniella friesei (Meade-Waldo, 1914) & Megachilidae & Eoanthidium rothschildi (Vachal) \\
\hline Apidae & Tetraloniella junodi (Friese, 1909) & Megachilidae & Euaspis abdominalis (Fabricius) \\
\hline Apidae & Tetraloniella katangensis (Cockerell, 1930) & Megachilidae & Euaspis abdominalis (Fabricius, 1773) \\
\hline Apidae & Tetraloniella michaelseni (Friese, 1916) & Megachilidae & Heriades arnoldi (Friese) \\
\hline Apidae & Tetraloniella minuta (Friese, 1905) & Megachilidae & Heriades bequerti (Cockerell) \\
\hline Apidae & Tetraloniella nanula (Cockerell, 1932) & Megachilidae & Heriades bouyssoui (Vachal, 1903) \\
\hline Apidae & Tetraloniella paulyi (Eardley, 2001) & Megachilidae & Heriades capicola (Strand, 1912) \\
\hline Apidae & Tetraloniella sierranila (Eardley, 1989) & Megachilidae & Heriades eximius (Friese) \\
\hline Apidae & Tetraloniella simpsoni (Meade-Waldo, 1914) & Megachilidae & Heriades fumipennis (Cockerell) \\
\hline Apidae & Tetraloniella sjoestedti (Friese, 1909) & Megachilidae & Heriades humilis (Cockerell) \\
\hline Apidae & Tetraloniella whiteheadi (Eardley, 1989) & Megachilidae & Heriades rufifrons (Cockerell, 1932) \\
\hline
\end{tabular}


TABLE 8: Continued.

\begin{tabular}{|c|c|c|c|}
\hline Family & Species & Family & Species \\
\hline Apidae & Thyreus abyssinicus (Radoszkowski, 1873) & Megachilidae & Heriades scutellatus (Friese, 1922) \\
\hline Apidae & Thyreus albomaculatus (DeGeer, 1778) & Megachilidae & Heriades speculiferus (Cockerell) \\
\hline Apidae & Thyreus axillaris (Vachal, 1903) & Megachilidae & Hoplitis infrapicta (Cockerell, 1916) \\
\hline Apidae & Thyreus bouyssoui (Vachal, 1903) & Megachilidae & Lithurgus pullatus (Vachal, 1903) \\
\hline Apidae & Thyreus calceatus (Vachal, 1903) & Megachilidae & Lithurgus spiniferus (Cameron) \\
\hline Apidae & Thyreus delumbatus (Vachal, 1903) & Megachilidae & Lithurgus spiniferus (Cameron, 1905) \\
\hline Apidae & Thyreus interruptus (Vachal, 1903) & Megachilidae & Megachile abessinica (Friese, 1915) \\
\hline Apidae & Thyreus meripes (Vachal) & Megachilidae & Megachile accraensis (Friese, 1903) \\
\hline Apidae & Thyreus neavei (Cockerell, 1933) & Megachilidae & Megachile aculeata (Vachal, 1910) \\
\hline Apidae & Thyreus niloticus (Cockerell, 1937) & Megachilidae & Megachile admixta (Cockerell, 1931) \\
\hline Apidae & Thyreus oxaspis (Cockerell, 1936) & Megachilidae & Megachile afra (Pasteels, 1965) \\
\hline Apidae & Thyreus pretextus (Vachal) & Megachilidae & Megachile albocincta (Radoszkowski, 1874) \\
\hline Apidae & Thyreus scotaspis (Vachal, 1903) & Megachilidae & Megachile aliceae (Cockerell, 1932) \\
\hline Apidae & Thyreus somalicus (Strand, 1911) & Megachilidae & Megachile altera (Vachal) \\
\hline Apidae & Thyreus stellifera (Cockerell) & Megachilidae & Megachile apiformis (Smith, 1853) \\
\hline Apidae & Xylocopa africana (Fabricius, 1781) & Megachilidae & Megachile attenuata (Vachal, 1910) \\
\hline Apidae & Xylocopa albiceps (Fabricius, 1804) & Megachilidae & Megachile aurifera (Cockerell) \\
\hline Apidae & Xylocopa apicalis (Smith, 1854) & Megachilidae & Megachile basalis (Smith, 1853) \\
\hline Apidae & Xylocopa braunsi (Dusmet and Y Alonso, 1924) & Megachilidae & Megachile battorensis (Meade-Waldo, 1912) \\
\hline Apidae & Xylocopa caffra (Linnaeus, 1767) & Megachilidae & Megachile beniticola (Strand, 1912) \\
\hline Apidae & Xylocopa calcarata (Le Veque, 1928) & Megachilidae & Megachile bilobata (Friese, 1915) \\
\hline Apidae & Xylocopa calens (Lepeletier, 1841) & Megachilidae & Megachile boswendica (Cockerell) \\
\hline Apidae & Xylocopa erythrina (Gribodo, 1894) & Megachilidae & Megachile burungana (Cockerell) \\
\hline Apidae & Xylocopa flavicollis (DeGeer, 1778) & Megachilidae & Megachile capitata (Smith, 1853) \\
\hline Apidae & Xylocopa flavorufa (DeGeer, 1778) & Megachilidae & Megachile chrysopogon (Vachal) \\
\hline Apidae & Xylocopa gaullei (Vachal, 1898) & Megachilidae & Megachile cincta (Fabricius) \\
\hline Apidae & Xylocopa gribodoi (Magretti, 1892) & Megachilidae & Megachile cognata (Smith, 1853) \\
\hline Apidae & Xylocopa hottentota (Smith, 1854) & Megachilidae & Megachile congruens (Friese) \\
\hline Apidae & Xylocopa imitator (Smith, 1854) & Megachilidae & Megachile coniformis (Friese, 1922) \\
\hline Apidae & Xylocopa inconstans (Smith, 1874) & Megachilidae & Megachile cornigera (Friese, 1904) \\
\hline Apidae & Xylocopa lateritia (Smith, 1854) & Megachilidae & Megachile crassitarsis (Cockerell, 1920) \\
\hline Apidae & Xylocopa mixta (Radoszkowski, 1881) & Megachilidae & Megachile curtula (Gerstaecker, 1857) \\
\hline Apidae & Xylocopa modesta (Smith, 1854) & Megachilidae & Megachile devexa (Vachal, 1903) \\
\hline Apidae & Xylocopa nigrita (Fabricius, 1775) & Megachilidae & Megachile digiticauda (Cockerell, 1937) \\
\hline Apidae & Xylocopa olivacea (Fabricius, 1778) & Megachilidae & Megachile discolor (Smith) \\
\hline Apidae & Xylocopa praeusta (Smith, 1854) & Megachilidae & Megachile dolichognatha (Cockerell) \\
\hline Apidae & Xylocopa pubescens (Spinola, 1838) & Megachilidae & Megachile dorsata (Smith, 1853) \\
\hline Apidae & Xylocopa senior (Vachal, 1899) & Megachilidae & Megachile edwardsiana (Friese, 1925) \\
\hline Apidae & Xylocopa torrida (Westwood, 1838) & Megachilidae & Megachile ekuivella (Cockerell, 1909) \\
\hline Apidae & Xylocopa ustulata (Smith, 1854) & Megachilidae & Megachile erythrura (Pasteels, 1970) \\
\hline Apidae & Xylocopa varipes (Smith, 1854) & Megachilidae & Megachile eupyrrha (Cockerell, 1937) \\
\hline Apidae & Xylocopa villosa (Friese, 1909) & Megachilidae & Megachile eurymera (Smith, 1864) \\
\hline Apidae & Xylocopa wellmani (Cockerell, 1906) & Megachilidae & Megachile excavata (Cockerell) \\
\hline Colletidae & Colletes eardleyi (Kuhlmann) & Megachilidae & Megachile fastigiata (Vachal) \\
\hline Colletidae & Colletes opacicollis (Friese) & Megachilidae & Megachile felina (Gerstäcker, 1857) \\
\hline Colletidae & Colletes reginae (Cockerell) & Megachilidae & Megachile fimbriata (Smith, 1853) \\
\hline Colletidae & Colletes rothschildi (Vachal) & Megachilidae & Megachile flavipennis (Smith, 1853) \\
\hline
\end{tabular}


Psyche

TABle 8: Continued.

\begin{tabular}{|c|c|c|c|}
\hline Family & Species & Family & Species \\
\hline Colletidae & Colletes rufitarsis (Friese) & Megachilidae & Megachile fulva (Smith, 1853) \\
\hline Colletidae & Colletes schultzei (Friese) & Megachilidae & Megachile fulvitarsis (Friese, 1910) \\
\hline Colletidae & Colletes somereni (Cockerell) & Megachilidae & Megachile fulvohirta (Friese, 1904) \\
\hline Colletidae & Hyaeus tinctulus (Cockerell) & Megachilidae & Megachile funebris (Radoszkowski, 1874) \\
\hline Colletidae & Hylaeus alfkeni (Friese, 1913) & Megachilidae & Megachile garambana (Pasteels) \\
\hline Colletidae & Hylaeus braunsi (Alfken, 1905) & Megachilidae & Megachile gastracantha (Cockerell) \\
\hline Colletidae & Hylaeus fortis (Cockerell) & Megachilidae & Megachile globiceps (Pasteels) \\
\hline Colletidae & Hylaeus heraldicus (Smith, 1853) & Megachilidae & Megachile gowdeyi (Cockerell, 1931) \\
\hline Colletidae & Hylaeus lineaticeps (Friese, 1913) & Megachilidae & Megachile gratiosa (Gerstäcker, 1857) \\
\hline Colletidae & Hylaeus magrettii (Vachal) & Megachilidae & Megachile griseola (Cockerell) \\
\hline Colletidae & Hylaeus neavei (Cockerell, 1942) & Megachilidae & Megachile hecate (Vachal) \\
\hline Colletidae & Hylaeus scutispinus (Alfken) & Megachilidae & Megachile hirticauda (Cockerell) \\
\hline Colletidae & Hylaeus subfortis (Cockerell) & Megachilidae & Megachile hopilitis (Vachal, 1903) \\
\hline Colletidae & Hylaeus ugandicus (Cockerell, 1939) & Megachilidae & Megachile ikuthaensis (Friese) \\
\hline Colletidae & Scrapter albitarsis (Friese, 1909) & Megachilidae & Megachile invenita (Pasteels) \\
\hline Colletidae & Scrapter algoensis (Friese, 1925) & Megachilidae & Megachile junodi (Friese, 1904) \\
\hline Colletidae & Scrapter amplispinatus (Eardley, 1996) & Megachilidae & Megachile laminata (Friese) \\
\hline Colletidae & Scrapter amplitarsus (Eardley, 1996) & Megachilidae & Megachile leucospila (Cockerell, 1933) \\
\hline Colletidae & Scrapter armatipes (Friese, 1913) & Megachilidae & Megachile lineofasciata (Pasteels, 1965) \\
\hline Colletidae & Scrapter aureiferus (Cockerell, 1932) & Megacliilidae & Megachile luteociliata (Pasteels) \\
\hline Colletidae & Scrapter avius (Eardley, 1996) & Megachilidae & Megachile mabirensis (Cockerell) \\
\hline Colletidae & Scrapter basutorum (Cockerell, 1915) & Megachilidae & Megachile mackieae (Cockerell, 1937) \\
\hline Colletidae & Scrapter bicolor (Lepeletier and Audi & Megachilidae & Megachile maculosella (Pasteels, 1965) \\
\hline Colletidae & Scrapter caesariatus (Eardley, 1996) & Megachilidae & Megachile manyara (Eardley and Urban) \\
\hline Colletidae & Scrapter calx (Eardley, 1996) & Megachilidae & Megachile masaiella (Cockerell, 1930) \\
\hline Colletidae & Scrapter capensis (Friese, 1909) & hilidae & Megachile meadewaldoi (Brauns, 1912) \\
\hline Colletidae & Scrapter catoxys (D & rachilidae & Megachile mimetica (Cockerell) \\
\hline Colletidae & Scrapter chloris & Megachilidae & $\begin{array}{l}\text { Megachile mixtura (Eardley and R. P. Urban, } \\
\text { 2005) }\end{array}$ \\
\hline Colletidae & Scrapter chrysomastes (Davies, 2005) & Megachilidae & Megachile nasalis (Smith, 1879) \\
\hline Colletidae & Scrapter erubescens (Friese, 1925) & Megachilidae & Megachile natalica (Cockerell, 1920) \\
\hline Colletidae & Scrapter flavipes (Friese, 1925) & Megachilidae & Megachile neavei (Vachal, 1910) \\
\hline Colletidae & Scrapter flavostictus (Cockerell, 1934) & Megachilidae & Megachile nigroaurea (Pasteels) \\
\hline Colletidae & Scrapter glarea (Davies, 2005) & Megachilidae & Megachile niveicauda (Cockerell, 1920) \\
\hline Colletidae & Scrapter heterodoxus (Cockerell, 1921) & Megachilidae & Megachile niveofasciata (Friese, 1904) \\
\hline Colletidae & Scrapter leonis (Cockerell, 1934) & Megachilidae & Megachile panda (Cockerell) \\
\hline Colletidae & Scrapter luridus (Eardley, 1996) & Megachilidae & Megachile paupera (Pasteels, 1965) \\
\hline Colletidae & Scrapter niger (Lepeletier and Audinet-Serville, 1825) & Megachilidae & Megachile perfimbriata (Cockerell, 1920) \\
\hline Colletidae & Scrapter nitidus (Friese, 1909) & Megachilidae & Megachile postnigra (Cockerell) \\
\hline Colletidae & Scrapter pallidipennis (Cockerell, 1920) & Megachilidae & Megachile pulvinata (Vachal) \\
\hline Colletidae & Scrapter pruinosus (Davies, 2006) & Megachilidae & Megachile pyrrhothorax (Schletterer, 1891) \\
\hline Colletidae & Scrapter pyretus (Davies, 2006) & Megachilidae & Megachile rosarum (Cockerell) \\
\hline Colletidae & Scrapter rufescens (Friese, 1913) & Megachilidae & Megachile rufa (Friese, 1903) \\
\hline Colletidae & Scrapter ruficornis (Cockerell, 1916) & Megachilidae & Megachile rufigaster (Cockerell, 1945) \\
\hline Colletidae & Scrapter striatus (Smith, 1853) & Megachilidae & Megachile rufipennis (Fabricius, 1793) \\
\hline Colletidae & Scrapter viciniger (Davies, 2006) & Megachilidae & Megachile rufipes (Fabricius, 1781) \\
\hline Colletidae & Scrapter whiteheadi (Eardley, 1996) & Megachilidae & Megachile scindularia (du Buysson) \\
\hline Halictidae & Ceylalictus muiri (Cockerell) & Megachilidae & Megachile selenostoma (Cockerell) \\
\hline
\end{tabular}


TABle 8: Continued.

\begin{tabular}{|c|c|c|c|}
\hline Family & Species & Family & Species \\
\hline Halictidae & Eupetersia similis (Benoist) & Megachilidae & Megachile semiflava (Cockerell, 1937) \\
\hline Halictidae & Evylaeus kampalensis (Cockerell) & Megachilidae & Megachile silverlocki (Meade-Waldo) \\
\hline Halictidae & Evylaeus latesellatus (Cockerell) & Megachilidae & Megachile simulator (Cockerell) \\
\hline Halictidae & Evylaeus microsellatus (Cockerell) & Megachilidae & Megachile sinuata (Friese, 1903) \\
\hline Halictidae & Evylaeus nigritulinus (Cockerell) & Megachilidae & Megachile striatula (Cockerell, 1931) \\
\hline Halictidae & Evylaeus semilucidus (Cockerell) & Megachilidae & Megachile torrida (Smith, 1853) \\
\hline Halictidae & Halictus bidens (Cameron) & Megachilidae & Megachile truncaticeps (Friese) \\
\hline Halictidae & Halictus chalybaeus (Friese, 1908) & Megachilidae & Megachile ungulata (Smith, 1853) \\
\hline Halictidae & Halictus fascialis (Smith) & Megachilidae & Megachile utra (Vachal) \\
\hline Halictidae & Halictus frontalis (Smith, 1853) & Megachilidae & Megachile venustella (Cockerell) \\
\hline Halictidae & Halictus harveyi (Cockerell) & Megachilidae & Megachile vittatula (Cockerell, 1920) \\
\hline Halictidae & Halictus jonesi (Cockerell) & Megachilidae & Megachile wahlbergi (Friese, 1901) \\
\hline Halictidae & Halictus obscurifrons (Cockerell, 1945) & Megachilidae & Megachile waterbergensis (Strand, 1911) \\
\hline Halictidae & Halictus picaninus (Cockerell) & Megachilidae & Noteriades tricarinatus (Bingham) \\
\hline Halictidae & Halictus placatus (Cockerell) & Megachilidae & Othinosmia braunsiana (Friese) \\
\hline Halictidae & Halictus rugicollis (Friese) & Megachilidae & Othinosmia globicola (Stadelmann, 1892) \\
\hline Halictidae & Halictus zonatus (Friese) & Megachilidae & Othinosmia nitidula (Cockerell) \\
\hline Halictidae & Lasioglossum aethiopicum (Cameron, 1905) & Megachilidae & Pachyanthidium apicatum (Smith) \\
\hline Halictidae & Lasioglossum bouyssoui (Vachal) & Megachilidae & Pachyanthidium benguelense (Vachal, 1903) \\
\hline Halictidae & Lasioglossum candidicinctum (Cockerell, 1945) & Megachilidae & Pachyanthidium bicolor (Lepeletier, 1841) \\
\hline Halictidae & Lasioglossum choronotum (Cockerell) & Megachilidae & Pachyanthidium bouyssoui (Vachal, 1903) \\
\hline Halictidae & Lasioglossum cinctulum (Cockerell) & Megachilidae & Pachyanthidium cordatum (Smith, 1854) \\
\hline Halictidae & Lasioglossum claripenne (Cockerell) & Megachilidae & Pachyanthidium micheneri (Pasteels) \\
\hline Halictidae & Lasioglossum duponti (Vachal, 1903) & Megachilidae & Pachyanthidium obscurum (Pasteels) \\
\hline Halictidae & Lasioglossum entebbianum (Coc & dae & $\begin{array}{l}\text { Pachyanthidium paulinieri } \\
\text { (Guérin-Méneville) }\end{array}$ \\
\hline Halictidae & Lasioglossum flavolineatum (Cockerell) & lae & Pachyanthidium rufescens (Friese, 1915) \\
\hline Halictidae & Lasioglossum geteinum (Cockerell, 1945) & Megachilidae & Pseudoanthidium lanificum (Smith, 1879) \\
\hline Halictidae & Lasioglossum gossypiellum (Cockerell) & Megachilidae & Pseudoanthidium truncatum (Smith, 1854) \\
\hline Halictidae & Lasioglossum griseocinctum (Cockerell) & & $\begin{array}{l}\text { Pseudoanthidium tuberculiferum (Brauns, } \\
\text { 1905) }\end{array}$ \\
\hline Halictidae & Lasioglo & Megachilidae & Pseudoheriades moricei (Friese, 1897) \\
\hline Halictidae & Lasioglossum macrurops (Cockerell, 1937) & Megachilidae & Pseudoheriades pellucidus (Cockerell) \\
\hline Halictidae & Lasioglossum masaiense (Cockerell) & Megachilidae & Serapista denticulata (Smith, 1854) \\
\hline Halictidae & Lasioglossum michaelseni (Friese, 191 & Megachilidae & Serapista rufipes (Friese, 1904) \\
\hline Halictidae & Lasioglossum moderatum (Benoist, 1962) & Megachilidae & Stenoheriades braunsi (Cockerell, 1932) \\
\hline Halictidae & Lasioglossum modestum (Benoist) & Megachilidae & Stenoheriades mackieae (Cockerell, 1936) \\
\hline Halictidae & Lasioglossum nairobicum (Cockerell, 1945) & Megachilidae & Stenoheriades truncaticeps (Friese, 1922) \\
\hline Halictidae & Lasioglossum nairobiense (Cockerell, 1945) & Melittidae & Capicola braunsiana (Friese, 1911) \\
\hline Halictidae & Lasioglossum namaense (Friese, 1909) & Melittidae & Capicola micheneri (Michez, 2007) \\
\hline Halictidae & Lasioglossum natense (Cockerell, 1935) & Melittidae & Haplomelitta atra (Michener, 1981) \\
\hline Halictidae & Lasioglossum nudatum (Benoist, 1962) & Melittidae & Meganomia andersoni (Meade-Waldo, 1916) \\
\hline Halictidae & Lasioglossum nyasense (Cockerell, 1945) & Melittidae & Meganomia binghami (Cockerell, 1909) \\
\hline Halictidae & Lasioglossum pachyacanthum (Cockerell, 1937) & Melittidae & Melitta albida (Cockerell, 1935) \\
\hline Halictidae & Lasioglossum pellitosum (Cockerell, 1934) & Melittidae & Melitta arrogans (Smith, 1879) \\
\hline Halictidae & Lasioglossum pernotescens (Cockerell, 1934) & Melittidae & Melitta danae (Eardley, 2006) \\
\hline Halictidae & Lasioglossum plicatinum (Cockerell) & Melittidae & Melitta katherinae (Eardley, 2006) \\
\hline Halictidae & Lasioglossum radiatulum (Cockerell, 1937) & Melittidae & Melitta schultzei (Friese, 1909) \\
\hline Halictidae & Lasioglossum rubricaude (Cameron, 1905) & Melittidae & Melitta whiteheadi (Eardley, 2006) \\
\hline Halictidae & Lasioglossum rubritarse (Cockerell) & Melittidae & Rediviva colorata (Michener, 1981) \\
\hline Halictidae & Lasioglossum rufomarginatum (Smitl & Melittidae & $\begin{array}{l}\text { Rediviva emdeorum (Vogel and Michener, } \\
\text { 1985) }\end{array}$ \\
\hline Halictidae & Lasioglossum semidiversum (Cockerell, 1940) & Melittidae & Redivivoides simulans (Michener, 1981) \\
\hline
\end{tabular}


Psyche

TABle 9: Morpho species and doubtful identification.

\begin{tabular}{|c|c|c|c|}
\hline Family & Morpho species & Family & Morpho species \\
\hline Andrenidae & Andrena sp.1 & Halictidae & Nomia sp.2 \\
\hline Andrenidae & Andrena sp.2 & Halictidae & Nomia (Leuconomia) sp. \\
\hline Andrenidae & Melitturga sp.2 & Halictidae & Nomia (Acunomia) sp. \\
\hline Andrenidae & Melitturga sp.1 & Halictidae & Nomia (Crocisapidia) sp. \\
\hline Andrenidae & Melitturgula sp.1 & Halictidae & Nomia sp.1 \\
\hline Andrenidae & Meliturgula sp.2 & Halictidae & Nomioides sp. \\
\hline Apidae & Afromelecta sp. & Halictidae & Patellapis sp. 3 \\
\hline Apidae & Allodape sp.1 & Halictidae & Patellapis (Archihalictus) sp. \\
\hline Apidae & Allodape sp. 2 & Halictidae & Patellapis (Chaetalictus) sp. \\
\hline Apidae & Allodapula sp.1 & Halictidae & Patellapis (Lomatalictus) sp. \\
\hline Apidae & Amegilla sp.1 & Halictidae & Patellapis (Zonalictus) sp.1 \\
\hline Apidae & Ammobates sp. & Halictidae & Patellapis (Zonalictus) sp. 2 \\
\hline Apidae & Anthophora sp.1 & Halictidae & Patellapis sp.1 \\
\hline Apidae & Anthophora sp.2 & Halictidae & Patellapis sp.2 \\
\hline Apidae & Braunsapis sp. & Halictidae & Patellapis sp.4 \\
\hline Apidae & Ceratina (Ctenoceratina) sp.1 & Halictidae & Pseudapis sp.1 \\
\hline Apidae & Ceratina (Ctenoceratina) sp. 2 & Halictidae & Pseudapis sp.2 \\
\hline Apidae & Ceratina (Neoceratina) sp. & Halictidae & Sphecodes sp. \\
\hline Apidae & Ceratina (Pithitis) sp. & Halictidae & Thrinchostoma sp. \\
\hline Apidae & Ceratina sp.1 & Halictinae & Halictus sp.1 \\
\hline Apidae & Ceratina sp. 2 & Halictinae & Halictus sp. 2 \\
\hline Apidae & Ceratina sp. 3 & Megachilidae & Afranthidium sp. \\
\hline Apidae & Cleptotrigona sp. & Megachilidae & Afroheriades sp.1 \\
\hline Apidae & Compsomelissa sp.1 & Megachilidae & Anthidiellum sp.1. \\
\hline Apidae & Ctenoplectra sp. 2 & Megachilidae & Anthidiellum sp.2. \\
\hline Apidae & Ctenoplectra sp.1 & Megachilidae & Anthidium (Severanthidium) sp.1 \\
\hline Apidae & Ctenoplectrina sp. & Megachilidae & Anthidium sp. \\
\hline Apidae & Dactylurina sp. & Megachilidae & Dianthidium sp.1 \\
\hline Apidae & Epeolus sp. & Megachilidae & Euasapis sp \\
\hline Apidae & Liotrigona sp. & Megachilidae & Fidelia sp \\
\hline Apidae & Melecta sp. & Megachilidae & Heriades sp.1 \\
\hline Apidae & Nomada sp. & Megachilidae & Heriades (Amboheriades) sp. \\
\hline Apidae & Pachymelus sp.1 & Megachilidae & Heriades (Pachyheriades) sp. \\
\hline Apidae & Pachymelus sp.2 & Megachilidae & Heriades sp.2 \\
\hline Apidae & Pachymelus sp.2 & Megachilidae & Hoplitis sp.1 \\
\hline Apidae & Pasites sp. 2 & Megachilidae & Hoplitis sp. 2 \\
\hline Apidae & Pasites sp.1 & Megachilidae & Lithurge sp \\
\hline Apidae & Sphecodopsis sp. & Megachilidae & Lithurgus sp \\
\hline Apidae & Tetralonia sp.1 & Megachilidae & Megachile (Amegachile) sp. \\
\hline Apidae & Tetralonia sp.2 & Megachilidae & Megachile (Creightonella) sp.1 \\
\hline Apidae & Tetralonia (Eucara) sp.1 & Megachilidae & Megachile (Creightonella) sp.2 \\
\hline Apidae & Tetralonia (Eucara) sp.2 & Megachilidae & Megachile (Creightonella) sp.3 \\
\hline Apidae & Tetralonia sp.3 & Megachilidae & Megachile (Eutricharaea) sp.1 \\
\hline Apidae & Tetraloniella sp. 4 & Megachilidae & Megachile (Eutricharaea) sp.2 \\
\hline Apidae & Tetraloniella sp.1 & Megachilidae & Megachile (Paracella) sp. \\
\hline Apidae & Tetraloniella sp. 2 & Megachilidae & Megachile (Xeromegachile) sp. \\
\hline Apidae & Tetraloniella sp. 3 & Megachilidae & Megachile sp.1 \\
\hline Colletidae & Colletes sp.1 & Megachilidae & Megachile sp.2 \\
\hline Colletidae & Colletes sp. 2 & Megachilidae & Noteriades sp. \\
\hline Colletidae & Hylaeus sp.1 & Megachilidae & Osmia sp.1 \\
\hline Colletidae & Hylaeus sp. 2 & Megachilidae & Osmia sp.2 \\
\hline Colletidae & Scrapter sp. & Megachilidae & Pachyanthidium sp. \\
\hline
\end{tabular}




\begin{tabular}{|c|c|c|}
\hline Morpho species & \multicolumn{2}{|c|}{ TABLE 9: Continued. } \\
\hline Scrapter sp.1 & Megachilidae & Pseudoanthidium sp. \\
\hline Scrapter sp. 2 & Megachilidae & Pseudoheriades sp. \\
\hline Cellariella sp.1 & Megachilidae & Serapista sp.1 \\
\hline Cellariella sp.2 & Megachilidae & Serapista sp. 2 \\
\hline Ceylalictus sp & Megachilidae & Stenoheriades sp. \\
\hline Lasioglossum sp.1 & Melittidae & Capicola sp \\
\hline Lasioglossum sp. 2 & Melittidae & Capicola sp \\
\hline Lasioglossum sp.3 & Melittidae & Haplomelitta sp. \\
\hline Lipotriches sp.1 & Melittidae & Meganomia sp. \\
\hline Lipotriches (Afronomia) sp & Melittidae & Melitta sp.2 \\
\hline Lipotriches (Macronomia) sp. & Melittidae & Melitta sp.1 \\
\hline Lipotriches (Trinomia) sp. & Melittidae & Rediviva sp.1 \\
\hline Lipotriches sp.2 & Melittidae & Rediviva sp. 2 \\
\hline & Melittidae & Redivivoides sp. \\
\hline
\end{tabular}

In West Indies, the effects of climate on the plant-pollinator communities were studied, and it was found that rainfall and temperature affected richness and importance of the different pollinator functional groups and species. It was found in that study that rainfall explained most of the variation in pollinator richness and relative importance. However, effect of climate on other insect pollinator groups was more obscure [55]. Bees were strongly negatively affected by rainfall. Bee variation along the climate gradient could therefore be largely explained by their physiological capabilities to respond to rainfall and temperature [55].

While comparing historical pollination rates to present rates of visitations by pollinators to an orchid plant species in RSA, a decline in the pollination and in pollinator species richness and abundance was found [32]. Similarly, in a recent study in the USA, climate data suggested that patterns of precipitation in the current and previous year climate change drove variation in bee abundance because of its effects on cues for bee emergence in the current year and on the abundance of floral resources in the previous year $[32,55]$. Thus, it is likely that accounting for the cumulative effects of climatic variables may be relevant for studying and predicting the future of bee communities in rural landscapes under climate change scenarios in Uganda.

Temporal and spatial fluctuations in the frequency of occurrence of different bee species can be associated with local climatic variation. In particular, bee abundance appeared in this study to be influenced positively by precipitation during previous years. The effects of the previousyear precipitation is likely indirect; greater precipitation tends to increase flower production in different bee food plants, which in turn may increase the food supply and reproductive success of generalist and specialist bees. This has consequence on the reproduction, emergence, phenology, and seasonality of bees, particularly for univoltine specialist solitary bees. Population dynamic in oligolectic bees (as opposed to polylectic bees) in response to year-to-year variation in floral resources may be also linked to previous climatic factors than to current ones [17]. Time lag in the population dynamics of bees in response to their food plants may also help in explaining in part dramatic fluctuations that can be observed in the visitation rates of different bee species to crop and wild blooming plant species.

In this study, it was also observed that rains two years prior to sampling had an effect on current bee populations. This was an indication of a potential long-term factor effects in shaping bee communities from rural landscapes of central Uganda. Although the average lifetime of the bee is much less than 1-2 years, it may appear controversial that past rainfall and temperature correlate with current/existing bee richness and abundance. In addition, such significant correlations may provide an indication of what has been happening as well as enabling speculative prediction of the future of species richness and abundance of bees in face of variability in climatic factors and the consequence on food security and livelihoods of people. Thus, studying separately (alone) the effects of current (specific period) weather factors on bee species richness and abundance may not provide an idea on the vulnerability of different bee species to future climate change. However, correlating weather data collected 2 to $\geq 10$ years prior to the current period of the study is preliminary proven to be indicative in terms of predicting the vulnerability and risk of extension of various bee species to climate change and global environmental change.

Results of this study indicated variability in 10-year average temperature and rainfall. This variability was due to fact that the study area is located around the Equator. Previous observations of weather data in Uganda indicated a high variability in micro- and macroclimatic factors at a small-scaled scale [18]. Thus, this may also explain variability in response of bee species and individuals to variability in rainfall and temperature among study sites when these study sites cover a relatively small geographic region in Uganda (12\% of the national land area).

In this study, it was also observed that bee species richness was correlated with previous climatic factors than current. 
Psyche

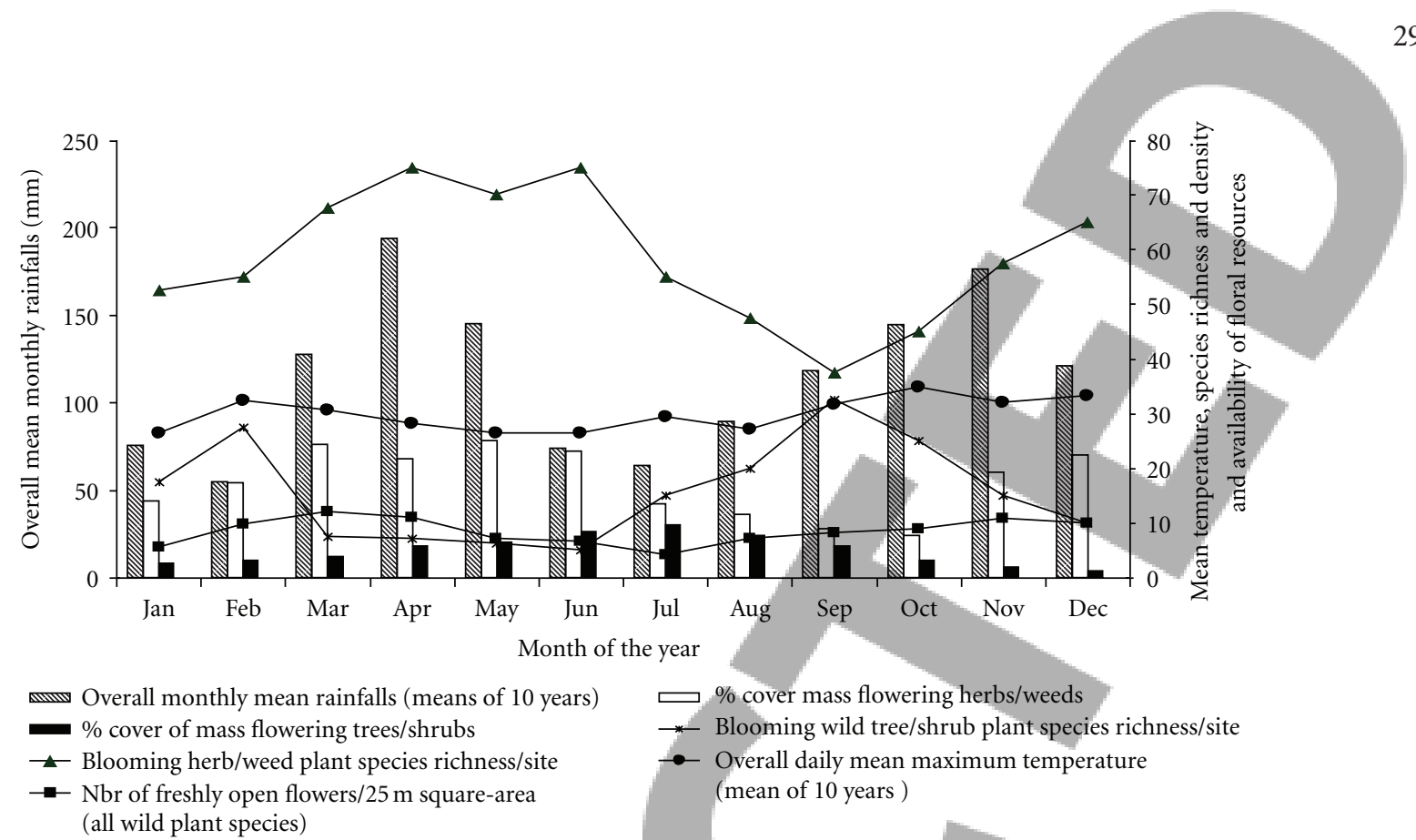

E 2: Trends in blooming wild plant species richness and abundance in relationships to rainfall and maximum temperature patterns in central Uganda. Blooming plant species richness and abundance had a significant correlation $(r=0.35, P<0.05)$ with rainfall. The minor wet season (September-November) to early dry season (December-January) had more diverse blooming plant species with greater availability of herbs/weeds than trees and shrubs. However, both trees/shrubs and herbs/weeds blooming groups were least in June during the major wet season. Blooming tree/shrub richness showed a highly significant inverse correlation $(r=0.36, P<0.05)$ with rainfall patterns. They declined a month ago after the start of the minor and major rainy seasons (September-March) and increased quickly two months later. This indicated that the two wild plant groups were not all in bloom at the same moment, and this is interesting for bees that need cover of floral resources around the year. Most (90\%) blooming herbs and weeds were in full bloom towards the end of the major wet season and peaked in June-July when the maximum temperature was not high. The number of fresh flowers per $25 \mathrm{~m}$ square was not correlated to neither rainfall $(r=0.14, P>0.05)$ nor to maximum temperature $(r=0.16, P>0.05)$.

Variability in climatic factors is expected over large areas (separated by more than $50 \mathrm{Km}$ ) as the data from the current study indicated. This variability in climatic factors has got consequences on occurrence/disappearance, seasonality, and voltinism of certain bee species found in central Uganda. Although there are almost no studies from East Africa and from Uganda predicting future impacts of climate change and variability on bee species richness and abundance, this study yielded preliminary results indicating potential vulnerability of bee biodiversity and its future consequence on yield stability and food security in the country.

Much remains to be learned about how bee species richness and abundance will respond to future climate change in different landscapes in Sub-Saharan Africa and in Uganda. There may be various mechanism responses of different bee species to climatic variability: delaying foraging dates and times and phenology shifts. Variability in terms of extinction or disappearance of certain functional groups may be catastrophic for certain groups of crops/plant species. The climatic variability may lead to increased pollen limitation in crop species [18]. Such situation may in turn lead to crop yield failure and food and livelihood insecurities of people, particularly rural communities where high reliance to pollination services is observed in most Sub-Saharan African countries. Hegland et al. [31] found that species phenological responses to climate warming often seem to occur at parallel magnitudes in plants and pollinators, sometimes resulting in temporal mismatches among these mutualistic partners. It has been also found that climate change-induced phenological shifts may reduce the floral resources available to different bee species by $17 \%-50 \%$, and this situation increases thereby extinction risks and disrupting crop/plant-pollinator interactions.

Central Uganda is the second African hotspot for bee biodiversity [22]. Future climate change is likely to particularly affect negatively and increase the risk of extinction of a number of bee species of local and unique Apoidea fauna found in central Uganda. Rising temperatures and altered rainfall regimes potentially have a huge impact on bee functional groups and life history traits like sociality in halictid bees [56] and host plant synchronization and, thus in turn, on pollination services and crop reproductive success.

In Uganda, future potential reductions in number of bee species and abundance were also predicted in this study. Novel mitigation mechanisms are highly needed to prevent decline in bee species and population in face of future climate change that may also alter crop/plant-pollinator mutualisms. For example, maintaining the spatio-temporal stability of bees (enhancing the persistence of populations) and their pollination services in the landscapes may require the establishment of observatories in rural landscapes. 


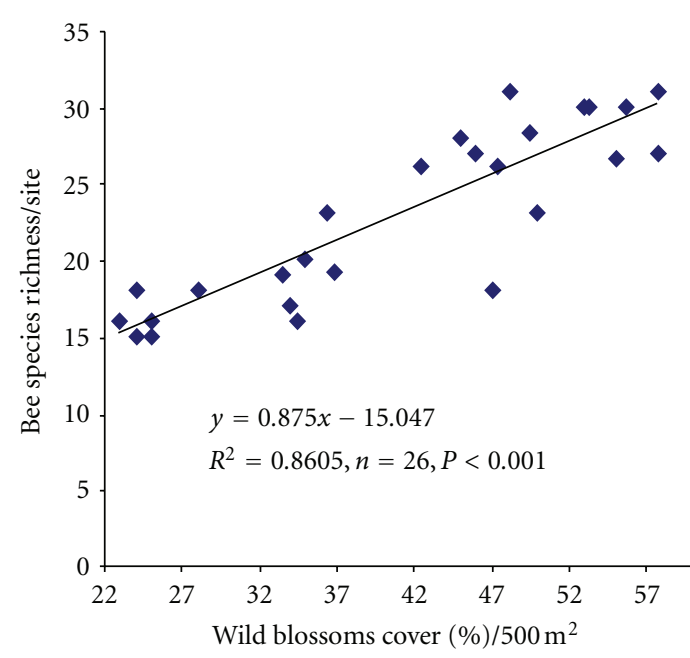

(a)

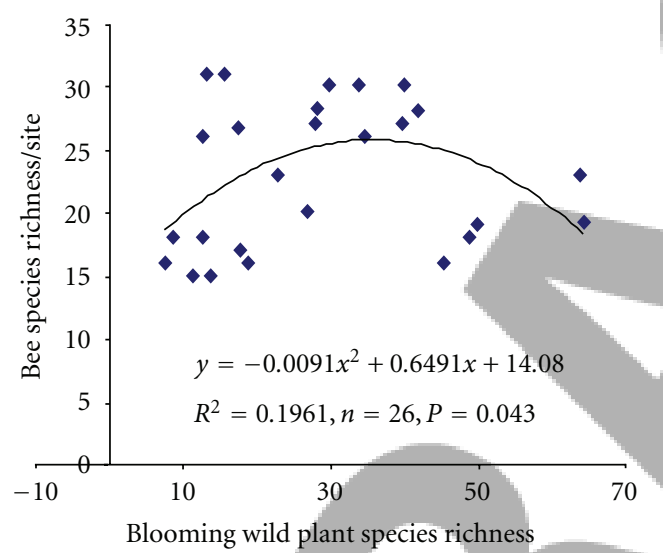

(c)

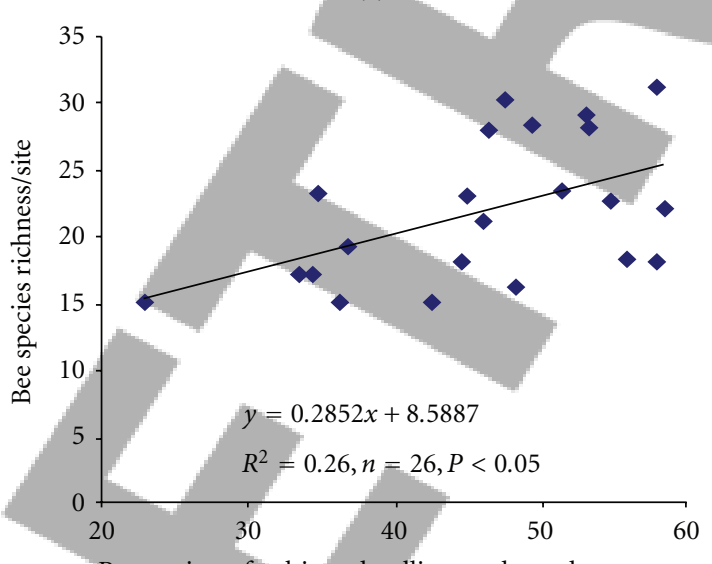

Proportion of cultivated pollinator-dependent crops

(e)

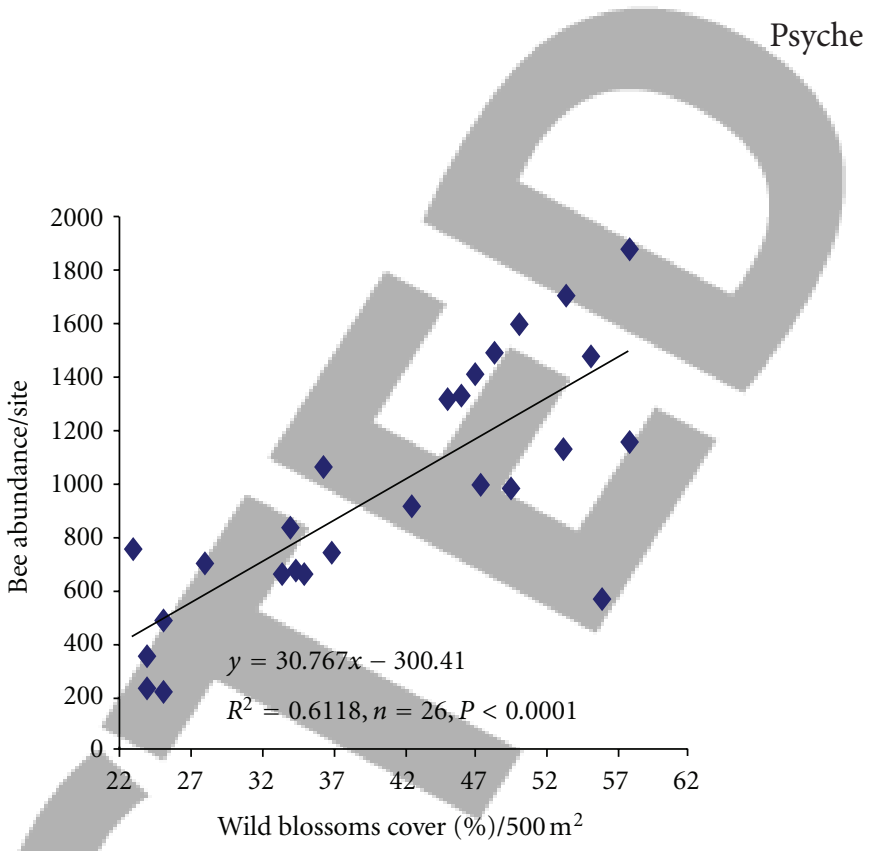

(b)

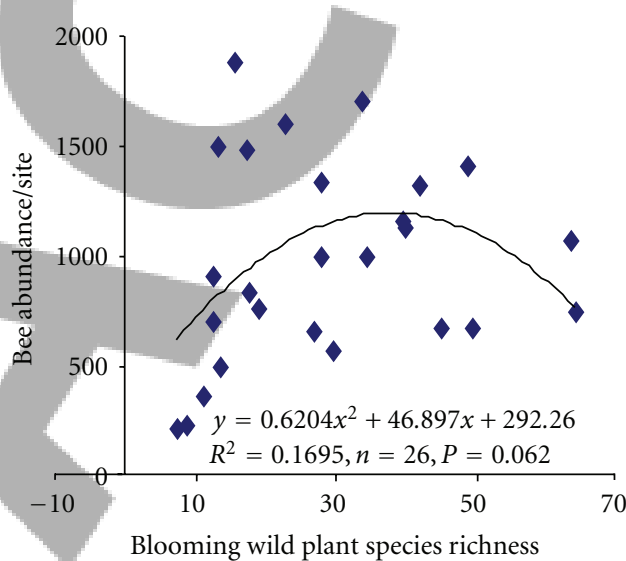

(d)

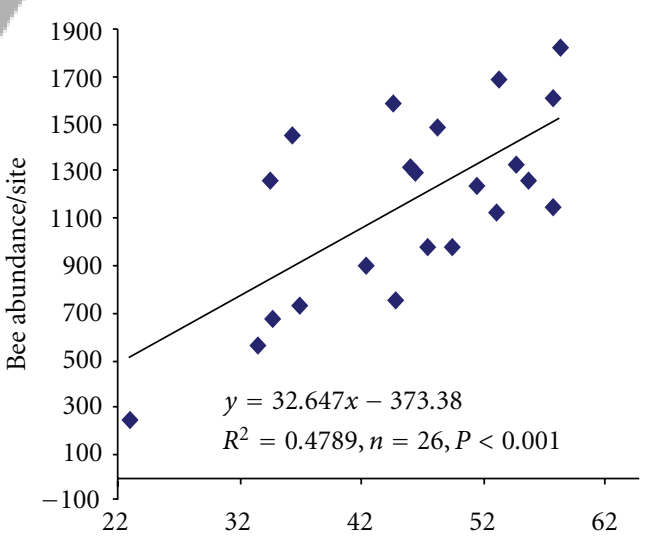

Proportion of cultivated pollinator-dependent crops

(f)

FIGURE 3: Relationship between (i) the abundance of wild floral resources (\% blossoms cover), (ii) the abundance of cultivated floral resources (\% of cultivated pollinator-dependent crops: all annual, bi-annual, perennial entomophilous crop species potentially offering pollen-nectar to bees), (iii) the number of flowering plant species (weeds, herbs, trees, and shrubs), and the number of bee species (a, c, and e) and bee abundance (b, d, and e) per study site. 


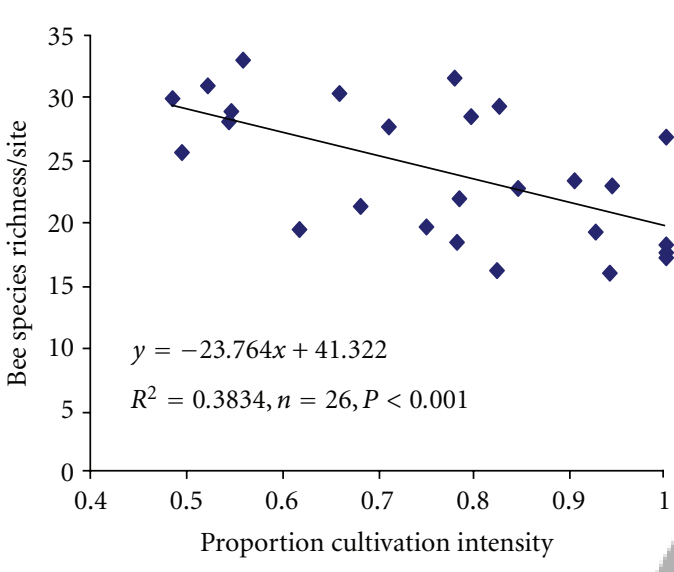

(a)

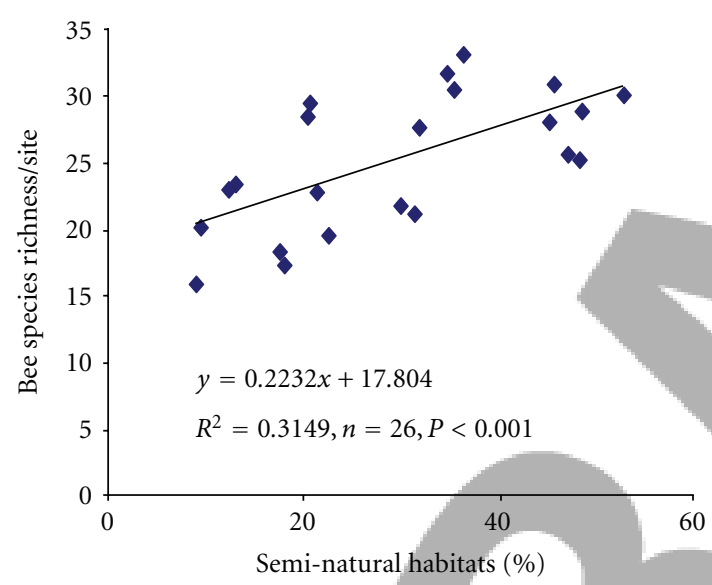

(c)

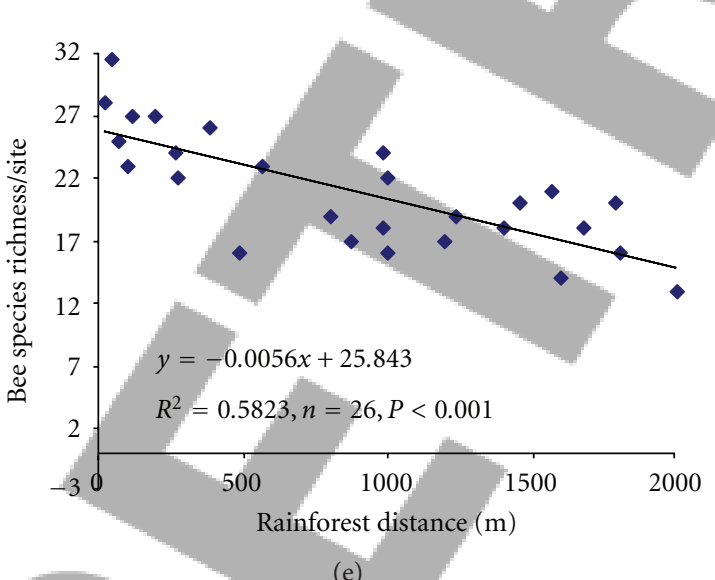

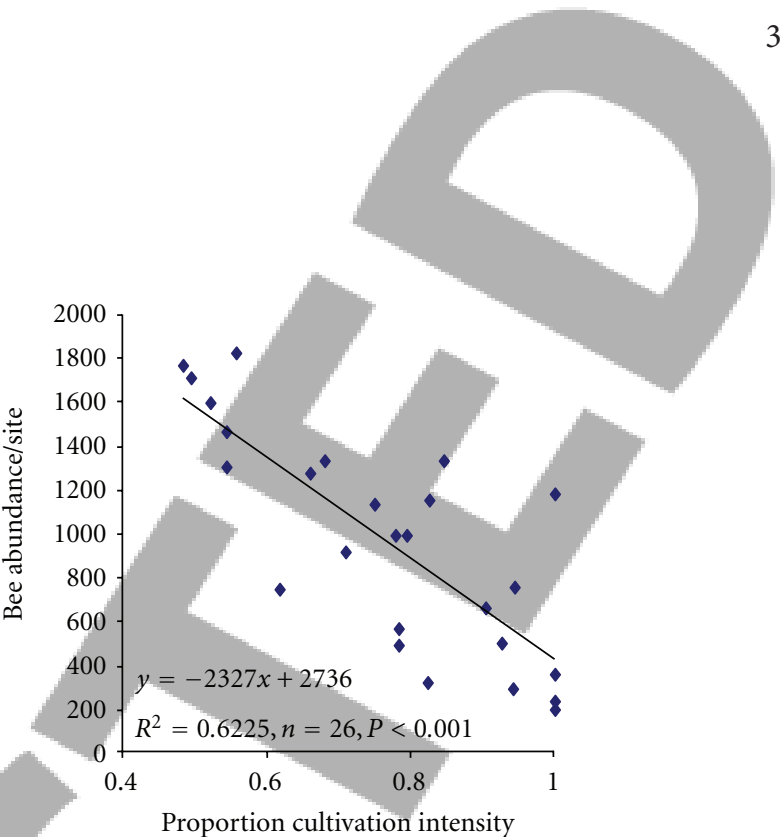

(b)

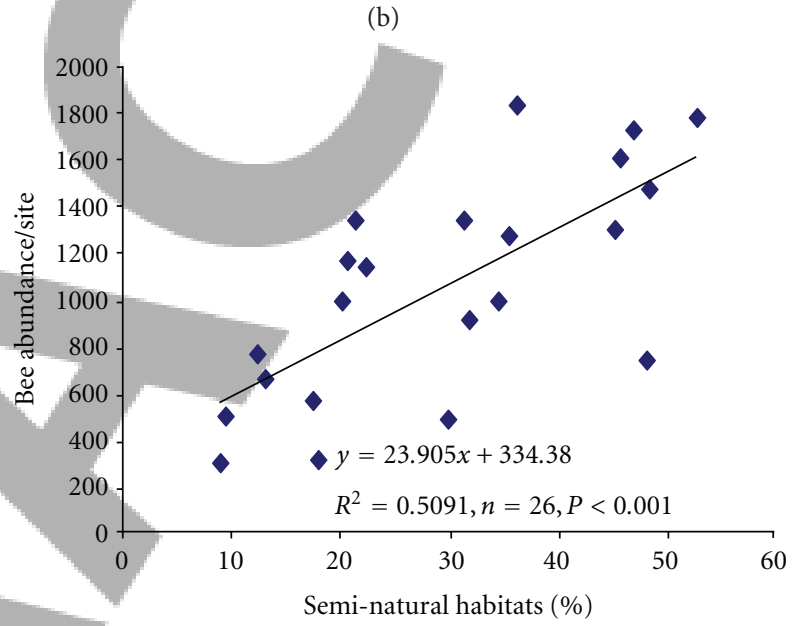

(d)

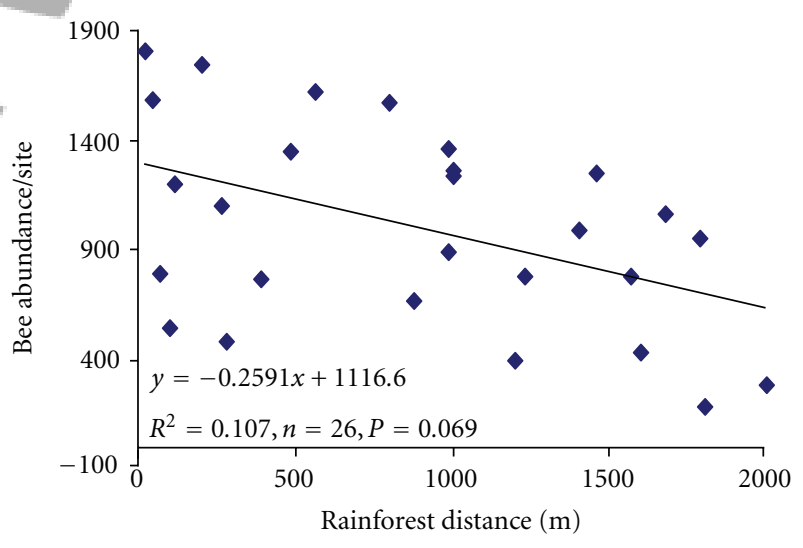

(f)

FIGURE 4: Relationship between landscape context variables (cultivation intensity, distance to forest margins, and \% of semi-natural habitats) per $\mathrm{Km}^{2}$-area and bee species richness (a, c, and e) and population density (b, d, and f) per study site. 
For successful conservation of bee biodiversity under climate change-induced habitat fragmentation/loss and availability of migration corridors and reserves, dispersal rates and colonization ability may be crucial factors to enhance in rural landscapes of central Uganda. Understanding and monitoring the effects of rising temperatures and changing precipitation regimes on bee species richness and population dynamics may be vital for the development of efficient landscape and habitat conservation strategies in rural landscapes of Uganda to enhance the delivery of pollination services to various pollinator-dependent crops/wild plants.

Given the relevance of crop/plant-pollinator mutualisms for biodiversity and ecosystem integrity and crop productivity in farmland of central Uganda, it is crucial that future in-deep studies/investigations on the impact of climate change (in interaction with various abiotic/biotic drivers) are conducted on crop-animal interactions in different ecological zones of Uganda, with a particular focus on vital pollination function and service stability enhancement.

Anthropogenic, environmental, and climatic changes and the introduction of alien species have been predicted to affect plant-pollinator interactions [57] and delivery of pollination services to crops at the global level. In addition prediction in parallel declines in bee species richness and insect-pollinated plants indicated a potential reduction in pollination services and/or in available flower resources for flower-visiting insects. Bees are important plant pollinators, but they are among biota that are very sensitive to disturbance; particularly to anthropogenic activities, intensification in landuse systems and change in farming practices. Any decline in numbers or species or functional groups of bees, due to anthropogenic disturbances in interaction with variability in climatic factors, has consequence for crop productivity in Uganda since $75 \%$ of crops grown by farmers are pollinatordependent crops [18]. Thus, the predicted population declines and species extinctions constitutes a significant threat both to biological diversity and their ecosystem services and to whole agricultural economics. The impacts of climate change on pollination services delivery may be more destructive in subSaharan Africa and in Uganda where there is a high livelihood dependency of human being to pollination services [18]. Thus the need to set and implement in advance climate-friendly conservation strategies before pollinators can disappear.

4.2. Effects of Regional Land-Use Intensity Factors on Bee Species Richness and Abundance. In this study, bee species richness and abundance were also found to be affected by regional land-use intensity variables as it was found in studies conducted elsewhere [1-3]. Results obtained from this study and those from other studies confirmed that the intensification of farmland management poses a threat to bee diversity $[44,58]$ and thus may reduce pollination services delivery to crops in rural landscapes. As human land-use intensifies, wild bees are exposed to habitat degradation/loss; exotic species (e.g., viruses, mites, and parasitoids) and spatial dissociation of food and nesting resources $[1,23,33]$, including native bees $[58,59]$. In rural landscapes of Uganda, bee communities are generally contingent on land-use, with solitary being more sensitive to anthropogenic activities than social bees [18]. Less anthropized areas generally harbor a greater richness and number of rare (singletons, doubletons) bee species while more intensively managed land-use types harbor higher population densities.

Land-use intensity may have indirect (reducing the diversity and cover of insect-pollinated plants, and thereby floral resources) negative effects on bee communities in rural landscapes. In fact, less intensively managed crop fields are expected to support more stable pollinator communities as a result of the higher availability of food resources. Higher stability of pollinators in rural landscapes has considerable effects on pollination success (e.g., reduced pollination limitation) and plant reproduction. Because bees are responsible for the pollination of many cultivated crops and wild plants, the decreased stability of bee communities (abundance and species richness), as well as the consequent decreased pollination services as a result of the negative impacts of land-use intensity (crop cultivation intensification) on bees, could have serious ecological and economical consequences $[1,58]$ in pollinator-dependent crop production systems of Uganda. Chronic pollen limitation caused by reduced pollinator availability is expected to result in strong crop yield failure/reduction and increase the likelihood of food insecurity of human communities.

From an ecological point of view, habitat loss, fragmentation (disruptions of habitat configuration and modification) are the major drivers of species extinction in the Anthropocene $[60,61]$ in the tropics. Their effects are exacerbated when interaction with climatic factors-stress related. Landscape disturbance primarily influences three components of pollination interactions: pollinator density, movement, and plant demography. The effects of habitat loss on each of these components are likely to differ substantially from the effects of fragmentation, which is likely to be more complex and may influence each pollination component in contrasting ways [60].

4.3. Effects of Local and Landscape Variables on Bee Communities. In this study, variations in bee abundance and species richness among different study locations were hypothesized to be related to landscape variables, but not to climatic and local variables. The results indicated the opposite. In fact, bee species richness and abundance were predicted by local factors (abundance and richness of floral resources) as well as by landscape and climatic factors. Thus, flowering (wild and cultivated) plants play significant role in structuring bee communities, particularly as sources of pollen and other floral resources needed for their survival in rural landscapes of central Uganda. In fact more than 24 flowering crop species (Table 6) and more than 50 wild blooming plant species (Table 7) were recorded during transect walk-and-counts in this study. Obviously, floral and nesting resources are critical for the occurrence/survival of diverse bee communities in natural and man-made landscapes [18]. Resource availability is a critical factor determining the dynamics of populations over space and time [62]. Several other studies have demonstrated that species richness of wild floral resources and 


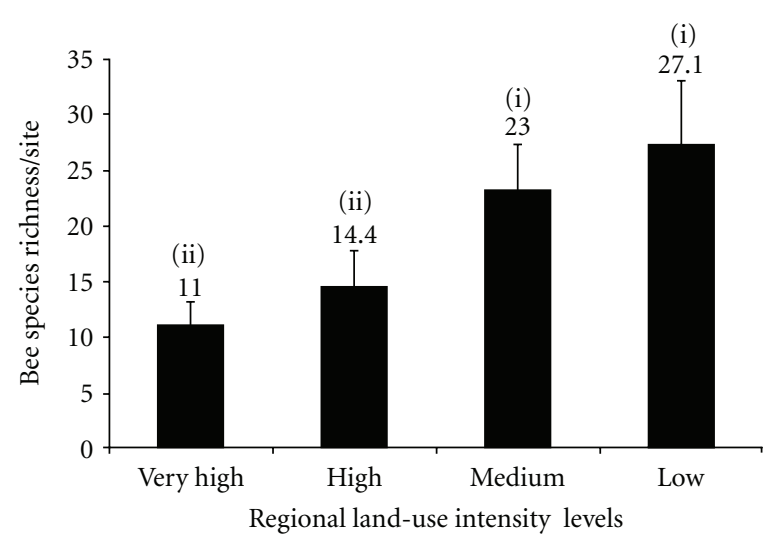

(a) [GLM-ANOVA, $F=5.22, P=0.007, \mathrm{DF}=(3,100)]$

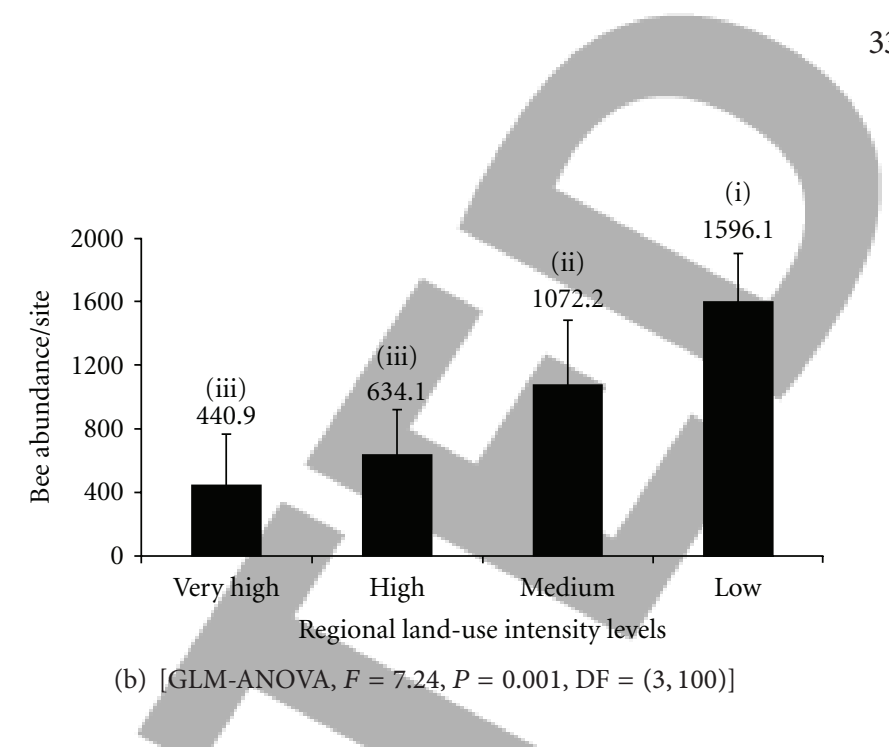

FIGURE 5: Effects of regional land-use intensity on the species richness (a) and abundances (b) of bees recorded per study site in farmlands of central Uganda. Error bars are \pm SE. Means $(x \pm$ se) followed by different letters are significantly different at $P<0.05$ according to Tukey test.

mass flowering of both wild plants and crop species actually influence both bee density and diversity that occur in farmed landscape [63-67].

Landscape variables (\% cultivation intensity, \% seminatural habitats, and forest distance) were observed to be powerful predictive variables of the variation in abundance, richness, and diversity of bees; few farm-scaled local variables (\% of wild floral resources) were equally powerful, whereas most of the local variables were significant but had weaker to nonsignificant effects.

In other words, landscape variables explained more variation in population density and species richness of bees than did local factors. In fact, bee species richness and abundance declined with forest distance. Geographic scales at which landscape effects on bee faunas are most pronounced remain largely unsurveyed in Sub-Saharan Africa. However, bee communities were observed to be affected by food resources within $0-200 \mathrm{~m}$ of their nesting sites [18]. As previously mentioned, forging habitat and nectar/pollen sources (located at $<2000 \mathrm{~m}$ far from bee refugia) are critical ecological resources for maintaining pollination services by native bees in agricultural landscapes $[7,59]$. Recently, in coffee-agroforest systems in India, it was found that the abundance of Apis dorsata decreased with increasing distance from a neighbouring forest patch, but this distance effect was reduced with an increase in size of the nearby forest [66], and this result indicated that justifying the conservation of large forest remnants may be problematic unless more studies are conducted to account for the direct effect of forest on crop fruit/seed set in most agricultural landscapes of the world [66].

Bee species and abundance were found to be linearly related to cover of semi-natural habitats although some studies $[22-24,27-30,35]$ have found that bee species richness may be positively but non necessarily being linearly related to semi-natural habitat area. Studies conducted elsewhere stressed that landscape factors (\% cover of semi-natural habitats, forest distance, and habitat fragmentation/isolation) are more important in determining the rule of occurrence [34] of Apoidea communities in rural landscapes [65-69]. Also, while investigating the effect of the quantity of surrounding natural habitat, organic management, and strips of seminatural vegetation on flower visitation frequency of wild and managed bees in intensive agricultural landscapes in USA, it was realized that wild bee species visited almond flowers but only in orchards with adjacent semi-natural habitat or vegetation strips [1].

Linear remnants of native vegetation and related seminatural habitats are known to contribute to bee assemblage heterogeneity by adding unique species to the regional pool [70]. In fact, semi-natural habitats and related noncrop habitats provide dispersal corridors and "habitat islands" required by many bee species as refuges and feeding areas [71]. Thus, an increase in amount of semi-natural habitats may lead to a more diverse flora in fields, providing valuable nesting and foraging resources for bees and other pollinators.

Although some farmland habitats may provide sufficient floral resources over the year, they may not be good nesting sites for bees. Short-distance to bee refugia (forest, wetlands, and remnant vegetation) and the percentage cover of seminatural habitats are attributes that contribute to bee diversity in rural landscapes. Bee species richness and diversity are expected to increase with increase in the amount of seminatural habitats in the landscapes $[72,73]$ because of availability of floral/nesting opportunities in such habitats [22,27]. Semi-natural habitats are known to positively affect pollinators in the surrounding agricultural landscape presumably through contributing both nest sites and forage resources. Other non-crop areas such as field margins may also be beneficial provided that they are rich in flower resources. Non-crop and semi-natural areas add heterogeneity to the farm-landscape. These non-crop habitats often provide a continuous supply of nectar and pollen which bees can utilize. They can provide suitable habitats for bees to nest and have been shown to contain higher densities of bee nests in this study. Hence, they may promote pollinator abundance and species richness in agricultural landscapes of Uganda, even if measures promoting pollinators may not necessarily 
benefit pollination of wild plants, because species may vary in their effectiveness as pollinators. Therefore, supporting wild pollinators and crop production in agricultural landscape requires the maintenance of mosaics of natural/semi-natural features and remnant vegetation in agricultural landscapes [70]. Networks of natural and semi-natural areas (hedgerows, grasslands, fallows, woodlands, riparian corridors, and roadsides) in the farmland can therefore be beneficial to agricultural production [9-11] although the effects of increasing semi-natural in the landscape may be taxon dependent [74] since some species richness may found beneficial while other many find these habitats hostile [74]. Because bees are among the important pollinator guilds in rural landscape, protection of the remaining natural habitat and vegetation in close proximity to farmland habitats is an imperative conservation strategy in host sport bee biodiversity regions.

Natural habitats, semi-natural habitats, and vegetation structure/composition generally explain most of the variance for the species richness and abundance of bees in agricultural landscapes [18]. There are a number of semi-natural habitats in the farmlands, but old fallows are generally associated with the highest species richness of bees. Other semi-natural habitats may harbor bee communities of similar species richness and composition [18]. In farm-landscapes with $20 \%-$ $30 \%$ of habitats kept uncultivated as reservoirs for bees, crop yields are expected to be stable over time and space [22]. Thus, conservation programs aiming at enhancing pollination services in the farm-landscape should concentrate on strategies to maintain/improve/increase the amount of seminatural habitats in the surrounding of crop fields to guarantee spatio-temporal availability of floral resources for beneficial insects including bees.

4.4. Contrasting Effects of Local and Landscape Factors on Bee Abundance, and Richness in Rural Landscapes. Occurrence, prevalence, abundance and richness of bees in rural landscapes may be linked to various local and landscapes. The degree at which different environmental characteristics influence bee communities is still subject of debate by scientists. Some studies have shown a relative high importance of landscape-scaled variables $[16,19]$ as compared to local-scale variables [18]. Overall, some studies stress that landscape variables are more determinants than local variables. Other studies indicate the importance of local variables in shaping bee communities variables. Within tropical regions, some studies often find that species richness and abundance are determined by local drivers, whereas studies from temperate regions report that landscape drivers are more determinants for bees in agricultural landscapes. For example, recently, Féon et al. [10] found that the abundance of bees (solitary bees) in fields increased positively with the increase in the proportion cover of semi-natural habitats (grasslands) than with increasing amount of flowering resources in an agricultural area of western France.

While in central Uganda both landscape and local factors had significant effect of bee abundance and diversity, in Mexico [75], it was recently found that local habitat factors, managed within agroforestry systems, had strong impacts on local bee abundance and species richness, more than landscape-level factors (e.g., \% cover of forests). Both the local and landscape factors affected bee communities in Uganda and this is different from what is commonly reported from elsewhere. For instance, there is no clear explanation for such pattern and difference. Explanations may be linked to the bee community composition found in central Uganda. The community composition plays a significant role in explaining this pattern since different bee species may respond differently at different local and landscape scaled factors $[23,30]$. In addition, in central Uganda, there coexist a diversity of bees with different nesting affinities and foraging ranges. There are evidences for existence of a high diversity of nesting resources and floral resources on which bees may depend on for pollen and nectar in farmlands of central Uganda [18]. Central Uganda had a variety of floral resources to support rich and diverse bee fauna. Some few common species may thus be affected (positively/negatively) by local factors (e.g., species flying at around $500 \mathrm{~m}$ from their nests), whereas others may only be affected by landscape factors (example species foraging up to $2000 \mathrm{~m}$ beyond their nests). Also, the difference in results between Uganda, and Mexico may be explained by the difference in local management strategies of fields. The diversity of floral resources combined to the diversity of nesting sites and to habitat heterogeneity was found to be likely explaining the survival and coexistence of great number of bee species with various ecological affinities in farmlands of central Uganda.

In brief, there is a need to conserve biodiversity to ensure the provision of ecosystem services in rural landscapes [75, 76] of Uganda and Sub-Saharan Africa. The conservation of pollinators and pollination services will play a significant role in a long-term viability of food supplies, in the livelihood security/improvement of smallholder farmers, in commercial agricultural enterprises, in generation of household and national revenues, and in production of diverse products to satisfy food, fibre, and fuel demands of expanding ruralurban populations.

\section{Conclusion and Recommendations}

The overall goal of this work was to understand how environmental characteristics operating at different scales affect the occurrence, distribution, and diversity of bee communities in farmlands of central Uganda. Understanding the response of species to various drivers is essential to designing conservation management, especially in mosaic agricultural landscapes. Aspects of the farm, surrounding landscape, and regional and climatic factors were found to be potentially useful predictors of bee abundance and species richness.

Overall, conservation, management, and policy efforts aiming at increasing ecological intensification of agricultural production systems and stabilizing food productivity in central Uganda should (i) first preserve and prevent degradation of remaining forest fragments, forest fallows, and wetlands: reducing natural and semi-natural vegetation clearance (retaining and maintaining the current status of natural forest patches and wetlands is important since these 
ecosystems increase the bee species richness in riparian agricultural matrices); (ii) secondly, strongly encouraging small-scale farmers to maintain higher cover of multipurpose agroforestry tree species and good proportion of linear and non-linear features of semi-natural habitats; (iii) mimicking natural vegetation or natural ecosystems through promoting establishment of related natural habitats (woodlots of eucalyptus/pines) and community village forestry in the rural landscapes.

The most critical point and exciting finding from this study was to find out that species richness/abundance correlated with mean annual temperatures in previous years. It was also found in this study that availability of semi-natural habitats, abundance of wild and cultivated floral resources in the landscape, and distance to the closest forest also influence critically the bee communities. Thus, changes in these landscape variables along the years are expected to affect bee communities as the change in average temperature/rainfall does. Hence, if landscape and land-use change data is found available (registered) in the region, further research should focus on potential influence of landscape changes on occurrence, distribution, and current community structure of bees. In fact, it is expected that the change in landscape variables may influence the change (variability) in climatic factors, and the lack of stability in climatic factors may have strong negative effects [18] on the spatiotemporal occurrence and distribution and distribution of bee communities in the agricultural landscape.

There is a need for future research to be conducted in many parts of the world to get more evidence of the role played by forest fragments, wetlands and related semi-natural habitats (e.g., forest fallows) in agricultural landscapes to provide a variety of ecosystem services [66]. There is also a need to increase scientific ability to define and experimentally measure pollination resilience, determine under which conditions there will be pollinator population stability, as well as increase the understanding of the factors shaping this parameter to be able to support efforts to forecast the impact of climate change on the delivery of pollination services to pollinator-dependent crops $[77,78]$. There is also a scientific need to estimate cost-benefits of conserving bee biodiversity and pollination services in natural and agricultural landscapes in [79] Uganda and in Sub-Saharan Africa. Findings from such studies may enable the development of opportunities to use semi-natural features in adaptation and mitigation activities related to future climate change.

\section{Conflict of Interests}
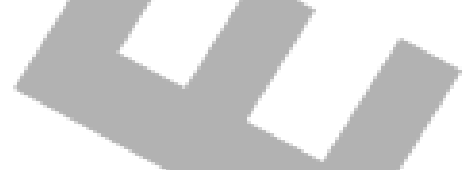

I declare having no conflict of interest with MINITAB Company. TheStatistical software used for data analysis (MINITAB-15, Englishversion) was officially purchased as single license use for onecomputer by the leader of the Darwin project (Dr Phil Atkinson fromBritish trust for ornithology) while in UK attending a training indata analysis between March and May 2007.

\section{Acknowledgments}

The author is very grateful to Darwin Initiative (Defra, UK; project reference: 14-032; project title: Conserving biodiversity in modernized farm landscapes in Uganda) for funding this study. Mr. Maurice Mutabazi (research assistant) is acknowledged for for his assistance in the field. He is also very grateful to Professor Simon Potts and Professor Philip Nyeko (scientific supervisors), as well as Dr. Juliet Vickery, Dr. Phil Atkinson, and Professor Derek Pomeroy (project scientific advisors) for all kind of help given. He is also very grateful to all bee taxonomists (Dr. Connal Eardley fromf ARC-RSA, Dr. David Roubik from Smithsonian Tropical Research Institute, Dr David Notton from the department of Entomology of Landon History Museums, UK, and Robert Stuart from the University of Reading, UK) who helped with proper identification and validation of names of different bee species collected during the course of this study.

\section{References}

[1] A. M. Klein, B. E. Vaissière, J. H. Cane et al., "Importance of pollinators in changing landscapes for world crops," Proceedings of Royal society of London B, vol. 274, no. 1608, pp. 303-313, 2007.

[2] C. Kremen, N. M. Williams, M. A. Aizen et al., "Pollination and other ecosystem services produced by mobile organisms: a conceptual framework for the effects of land-use change," Ecology Letters, vol. 10, no. 4, pp. 299-314, 2007.

[3] J. C. Watson, A. T. Wolf, and J. S. Ascher, "Forested landscapes promote richness and abundance of native bees (Hymenoptera: Apoidea: Anthophila) in Wisconsin apple orchards," Environmental Entomology, vol. 40, no. 3, pp. 621-632, 2011.

[4] D. W. Roubik, Pollination of Cultivated Plants in the Tropics, FAO, Rome, Italy, 1995.

[5] T. H. Ricketts, J. Regetz, I. Steffan-Dewenter et al., "Landscape effects on crop pollination services: are there general patterns?" Ecology Letters, vol. 11, no. 5, pp. 499-515, 2008.

[6] R. Winfree, D. Cariveau, and I. Bartomeus, "Native pollinators in anthropogenic habitats," Annual Review of Ecology, Evolution, and Systematics, vol. 42, pp. 1-22, 2011.

[7] R. Winfree, B. J. Gross, and C. Kremen, "Valuing pollination services to agriculture," Ecological Economics, vol. 71, pp. 80-88, 2011.

[8] J. C. Biesmeijer, S. P. M. Roberts, M. Reemer et al., "Parallel declines in pollinators and insect-pollinated plants in Britain and the Netherlands," Science, vol. 313, no. 5785, pp. 351-354, 2006.

[9] S. G. Potts, P. G. Kevan, and J. W. Boone, "Conservation in Pollination: collecting, surveying and monitoring," in Pollination Ecology: A Practical Approach, A. Dafni and P. Kevan, Eds., Enviroquest, Cambridge, UK, 2005.

[10] V. L. Féon, F. Burel, R. Chifflet et al., "Solitary bee abundance and species richness in dynamic agricultural landscapes," Agriculture, Ecosystems and Environment. In press.

[11] S. G. Potts, J. C. Biesmeijer, C. Kremen, P. Neumann, O. Schweiger, and W. E. Kunin, "Global pollinator declines: trends, impacts and drivers," Trends in Ecology and Evolution, vol. 25, no. 6, pp. 345-353, 2010.

[12] D. Moroń, I. M. Grzes, P. Skórka et al., "Abundance and diversity of wild bees along gradients of heavy metal pollution," Journal of Applied Ecology, vol. 49, no. 1, pp. 118-125, 2012. 
[13] A.-M. Klein, "Plant-pollinator interactions in changing environments," Basic and Applied Ecology, vol. 12, no. 4, pp. 279-281, 2011.

[14] R. Winfree, R. Aguilar, D. P. Vázquez, G. Lebuhn, and M. A. Aizen, "A meta-analysis of bees' responses to anthropogenic disturbance," Ecology, vol. 90, no. 8, pp. 2068-2076, 2009.

[15] C. D. Michener, The Bees of the World, The John Hopkins University Press, Baltimore, Md, USA, 2007.

[16] C. D. Eardley, M. Gikungu, and M. P. Schwarz, "Bee conservation in Sub-Saharan Africa and Madagascar: diversity, status and threats," Apidologie, vol. 40, no. 3, pp. 355-366, 2009.

[17] P. Hoehn, I. Steffan-Dewenter, and T. Tscharntke, "Relative contribution of agroforestry, rainforest and openland to local and regional bee diversity," Biodiversity and Conservation, vol. 19, no. 8, pp. 2189-2200, 2010.

[18] T. M. B. Munyuli, Pollinator biodiversity and economic value of pollination services in Uganda [Ph.D. dissertation], Makerere University, Kampala, Uganda, 2010.

[19] T. M. B. Munyuli, "Factors governing flower-visitation patterns and quality of pollination services delivered by social and solitary bee species to coffee in central Uganda," African Journal of Ecology, vol. 49, pp. 501-509, 2011.

[20] T. M. B. Munyuli, "Pollinator biodiversity in Uganda and in SubSahara Africa: landscape and habitat management strategies for its conservation," International Journal of Biodiversity and Conservation, vol. 3, pp. 551-609, 2011.

[21] T. M. B. Munyuli, "Farmers' perceptions of pollinators' importance in coffee production in Uganda," Agricultural Sciences, vol. 2, pp. 318-333, 2011.

[22] A. S. Persson and H. G. Smith, "Bumblebee colonies produce larger foragers in complex landscapes," Basic and Applied Ecology, vol. 12, pp. 695-702, 2011.

[23] T. Tscharntke, A. M. Klein, A. Kruess, I. Steffan-Dewenter, and C. Thies, "Landscape perspectives on agricultural intensification and biodiversity - ecosystem service management," Ecology Letters, vol. 8, no. 8, pp. 857-874, 2005.

[24] R. Bommarco, J. C. Biesmeijer, B. Meyer et al., "Dispersal capacity and diet breadth modify the response of wild bees to habitat loss," Proceedings of the Royal Society B, vol. 277, no. 1690, pp. 2075-2082, 2010.

[25] J. M. Tylianakis, A. M. Klein, and T. Tscharntke, "Spatiotemporal variation in the diversity of hymenoptera across a tropical habitat gradient," Ecology, vol. 86, no. 12, pp. 3296-3302, 2005.

[26] N. Gallai, J. M. Salles, J. Settele, and B. E. Vaissière, "Economic valuation of the vulnerability of world agriculture confronted with pollinator decline," Ecological Economics, vol. 68, no. 3, pp. 810-821, 2009.

[27] T. M. B. Munyuli, "Assessment of indicator species of butterfly assemblages in coffee-banana farming system in central Uganda," African Journal of Ecology, vol. 50, pp. 77-89, 2012.

[28] T. M. B. Munyuli, "Diversity of life-history traits, functional groups and indicator species of bee communities from farmlands of central Uganda," Jordan Journal of Biological Sciences, vol. 5, no. 1, pp. 1-14, 2012.

[29] T. M. B. Munyuli, "Micro, local, landscape and regional drivers of bee biodiversity and pollination services delivery to coffee (Coffea canephora) in Uganda," International Journal of Biodiversity, Ecosystem Services and Management, vol. 8, no. 3, pp. 190-203, 2012.

[30] T. M. B. Munyuli, "Is pan-trapping the most reliable sampling method for measuring and monitoring bee biodiversity in agroforestry systems in sub-Saharan Africa?" International Journal of Tropical Insect Science, vol. 33, no. 11, pp. 14-37, 2013.

[31] S. J. Hegland, A. Nielsen, A. Lázaro, A. L. Bjerknes, and $\varnothing$. Totland, "How does climate warming affect plant-pollinator interactions?" Ecology Letters, vol. 12, no. 2, pp. 184-195, 2009.

[32] D. A. Moeller, M. A. Geber, V. M. Eckhart, and P. Tiffin, "Reduced pollinator service and elevated pollen limitation at the geographic range limit of an annual plant," Ecology, vol. 93, no. 5, pp. 1036-1048, 2012.

[33] T. Tscharntke, Y. Clough, T. C. Wanger et al., "Global food security, biodiversity conservation and the future of agricultural intensification," Biological Conservation, vol. 151, no. 1, pp. 5359, 2012.

[34] J. Banaszak and T. Manole, "Diversity and density of pollinating insects (Apoidea) in the agricultural landscape of Romania," Polskie Pismo Entomologiczne, vol. 57, pp. 747-766, 1987.

[35] T. M. B. Munyuli, "Pollination services delivery and food security in Sub-Sahara Africa are highly threatened by future climate changes: preliminary evidences," in Proceedings of Climate Change Network Team Conference (CCNT '11), London, UK, September 2011 .

[36] C. Westphal, R. Bommarco, G. Carré et al., "Measuring bee diversity in different European habitats and biogeographical regions," Ecological Monographs, vol. 78, no. 4, pp. 653-671, 2008.

[37] M. W. Gikungu, Bee diversity and some aspects of their ecological interactions with plants in a successional tropical community [Ph.D. dissertation], University of Bonn, Bonn, Germany, 2006.

[38] R. Kajobe, Foraging behaviour of equatorial Afro-tropical stingless bees: habitat selection and competition for resources [Ph.D. thesis], University of Utrecht, Utrecht, The Netherlands, 2008.

[39] R. Rader, B. G. Howlett, S. A. Cunningham, D. A. Westcott, and W. Edwards, "Spatial and temporal variation in pollinator effectiveness: do unmanaged insects provide consistent pollination services to mass flowering crops?" Journal of Applied Ecology, vol. 49, pp. 126-134, 2012.

[40] A.-M. Klein, C. Brittain, S. D. Hendrix, R. Thorp, N. Williams, and C. Kremen, "Wild pollination services to California almond rely on semi-natural habitat," Journal of Applied Ecology, vol. 49, pp. 723-732, 2012.

[41] A.-M. Klein, I. Steffan-Dewenter, D. Buchori, and T. Tscharntke, "Effects of land-use intensity in tropical agroforestry systems on coffee flower-visiting and trap-nesting bees and wasps," Conservation Biology, vol. 16, no. 4, pp. 1003-1014, 2002.

[42] R. Grundel, R. P. Jean, K. J. Frohnapple, G. A. Glowacki, P. E. Scott, and N. B. Pavlovic, "Floral and nesting resources, habitat structure, and fire influence bee distribution across an openforest gradient," Ecological Applications, vol. 20, no. 6, pp. 16781692, 2010.

[43] E. Lonsdorf, C. Kremen, T. Ricketts, R. Winfree, N. Williams, and S. Greenleaf, "Modelling pollination services across agricultural landscapes.," Annals of Botany, vol. 103, no. 9, pp. 15891600, 2009.

[44] A. Kovács-Hostyánszki, P. Batáry, and A. Báldi, "Local and landscape effects on bee communities of Hungarian winter cereal fields," Agricultural and Forest Entomology, vol. 13, pp. 5966, 2011.

[45] A. Holzschuh, I. Steffan-Dewenter, D. Kleijn, and T. Tscharntke, "Diversity of flower-visiting bees in cereal fields: effects of farming system, landscape composition and regional context," Journal of Applied Ecology, vol. 44, no. 1, pp. 41-49, 2007. 
[46] M. C. B. Matos, L. Sousa-Souto, R. S. Almeida, and A. V. Teodoro, "Contrasting patterns of species richness and composition of solitary wasps and bees (Insecta: Hymenoptera) according to land-use," Biotropica, vol. 45, no. 1, pp. 73-79, 2013.

[47] C. Carvell, W. R. Meek, R. F. Pywell, D. Goulson, and M. Nowakowski, "Comparing the efficacy of agri-environment schemes to enhance bumble bee abundance and diversity on arable field margins," Journal of Applied Ecology, vol. 44, no. 1, pp. 29-40, 2007.

[48] L. E. Hannon and T. D. Sisk, "Hedgerows in an agri-natural landscape: potential habitat value for native bees," Biological Conservation, vol. 142, no. 10, pp. 2140-2154, 2009.

[49] S. G. Potts, B. A. Woodcock, S. P. M. Roberts et al., "Enhancing pollinator biodiversity in intensive grasslands," Journal of Applied Ecology, vol. 46, no. 2, pp. 369-379, 2009.

[50] A. Pauw and J. A. Hawkins, "Reconstruction of historical pollination rates reveals linked declines of pollinators and plants," Oikos, vol. 120, no. 3, pp. 344-349, 2011.

[51] A. E. Magurran, Measuring Biology Diversity, Blackwell Publishing, Oxford, UK, 2004.

[52] B. J. Brosi, P. R. Armsworth, and G. C. Daily, "Optimal design of agricultural landscapes for pollination services," Conservation Letters, vol. 1, pp. 27-36, 2008.

[53] J. Memmott, P. G. Craze, N. M. Waser, and M. V. Price, "Global warming and the disruption of plant-pollinator interactions," Ecology Letters, vol. 10, no. 8, pp. 710-717, 2007.

[54] O. Gordo and J. J. Sanz, "Temporal trends in phenology of the honey bee Apis mellifera (L.) and the small white Pieris rapae (L.) in the Iberian Peninsula (1952-2004)," Ecological Entomology, vol. 31, no. 3, pp. 261-268, 2006.

[55] A. M. M. González, B. Dalsgaard, J. Ollerton et al., "Effects of climate on pollination networks in the West Indies," Journal of Tropical Ecology, vol. 25, no. 5, pp. 493-506, 2009.

[56] M. Kuhlmann, D. Guo, R. Veldtman, and J. Donaldson, "Consequences of warming up a hotspot: species range shifts within a centre of bee diversity," Diversity and Distributions, vol. 18, no. 9, pp. 885-897, 2012.

[57] O. Schweiger, J. C. Biesmeijer, R. Bommarco et al., "Multiple stressors on biotic interactions: how climate change and alien species interact to affect pollination," Biological Reviews, vol. 85, no. 4, pp. 777-795, 2010.

[58] A. Hudewenz, A.-M. Klein, C. Scherber et al., "Herbivore and pollinator responses to grassland management intensity along experimental changes in plant species richness," Biological Conservation, vol. 150, no. 1, pp. 42-52, 2012.

[59] R. L. Callum, J. J. Bennie, D. T. Chris, J. A. Hodgson, and J. R. Wilson, "Local and landscape management of an expanding range margin under climate change," Journal of Applied Ecology, vol. 49, pp. 552-561, 2012.

[60] S. Krishnan, C. G. Kushalappa, R. U. Shaanker, and J. Ghazoul, "Status of pollinators and their efficiency in coffee fruit set in a fragmented landscape mosaic in South India," Basic and Applied Ecology, vol. 13, no. 3, pp. 277-285, 2012.

[61] A. S. Hadley and M. G. Betts, "The effects of landscape fragmentation on pollination dynamics: absence of evidence not evidence of absence," Biological Reviews, vol. 87, no. 3, pp. 526-544, 2012.

[62] N. M. Williams, J. Regetz, and C. Kremen, "Landscape-scale resources promote colony growth but not reproductive performance of bumble bees,' Ecology, vol. 93, no. 5, pp. 1049-1058, 2012.
[63] A. Sárospataki, A. Báldi, P. Batáry, Z. Józan, S. Erdõs, and T. Rédei, "Factors affecting the structure of bee assemblages in extensively and intensively grazed grasslands in Hungary," Community Ecology, vol. 10, no. 2, pp. 182-188, 2009.

[64] F. Kohler, J. Verhulst, R. van Klink, and D. Kleijn, "At what spatial scale do high-quality habitats enhance the diversity of forbs and pollinators in intensively farmed landscapes?" Journal of Applied Ecology, vol. 45, no. 3, pp. 753-762, 2008.

[65] M. Otieno, B. A. Woodcock, A. Wilby et al., "Local management and landscape drivers of pollination and biological control services in a Kenyan agro-ecosystem," Biological Conservation, vol. 144, no. 10, pp. 2424-2431, 2011.

[66] S. E. R. Hoover, J. J. Ladley, A. A. Shchepetkina, M. Tisch, S. P. Gieseg, and J. M. Tylianakis, "Warming, $\mathrm{CO}_{2}$, and nitrogen deposition interactively affect a plant-pollinator mutualism," Ecology Letters, vol. 15, no. 3, pp. 227-234, 2012.

[67] G. Carré, P. Roche, R. Chifflet et al., "Landscape context and habitat type as drivers of bee diversity in European annual crops," Agriculture, Ecosystems and Environment, vol. 133, no. 12, pp. 40-47, 2009.

[68] F. Jauker, T. Diekötter, F. Schwarzbach, and V. Wolters, "Pollinator dispersal in an agricultural matrix: opposing responses of wild bees and hoverflies to landscape structure and distance from main habitat," Landscape Ecology, vol. 24, no. 4, pp. 547$555,2009$.

[69] L. G. Carvalheiro, C. L. Seymour, R. Veldtman, and S. W. Nicolson, "Pollination services decline with distance from natural habitat even in biodiversity-rich areas," Journal of Applied Ecology, vol. 47, no. 4, pp. 810-820, 2010.

[70] P. E. Lentini, T. G. Martin, P. Gibbons, J. Fischer, and S. A. Cunningham, "Supporting wild pollinators in a temperate agricultural landscape: maintaining mosaics of natural features and production," Biological Conservation, vol. 149, pp. 84-92, 2012.

[71] E. Ockinger and H. G. Smith, "Semi-natural grasslands as population sources for pollinating insects in agricultural landscapes," Journal of Applied Ecology, vol. 44, pp. 50-59, 2007.

[72] I. Steffan-Dewenter and C. Westphal, "The interplay of pollinator diversity, pollination services and landscape change," Journal of Applied Ecology, vol. 45, no. 3, pp. 737-741, 2008.

[73] N. E. Sjödin, J. Bengtsson, and B. Ekbom, "The influence of grazing intensity and landscape composition on the diversity and abundance of flower-visiting insects," Journal of Applied Ecology, vol. 45, no. 3, pp. 763-772, 2008.

[74] T. Kehinde and M. J. Samways, "Endemic pollinator response to organic vs. conventional farming and landscape context in the Cape Floristic Region biodiversity hotspot," Agriculture, Ecosystems and Environment, vol. 146, pp. 162-167, 2012.

[75] S. Jha and J. H. Vandermeer, "Impacts of coffee agroforestry management on tropical bee communities," Biological Conservation, vol. 143, no. 6, pp. 1423-1431, 2010.

[76] C. Brittain and S. G. Potts, "The potential impacts of insecticides on the life-history traits of bees and the consequences for pollination," Basic and Applied Ecology, vol. 12, no. 4, pp. 321331, 2011.

[77] R. T. Gilman, N. S. Fabina, K. C. Abbott, and N. E. Rafferty, "Evolution of plant-pollinator mutualisms in response to climate change," Evolutionary Applications, vol. 5, no. 1, pp. 2-16, 2012.

[78] N. Pettorelli, "Climate changes as a main driver of ecological research," Journal of Applied Ecology, vol. 49, pp. 542-545, 2012. 


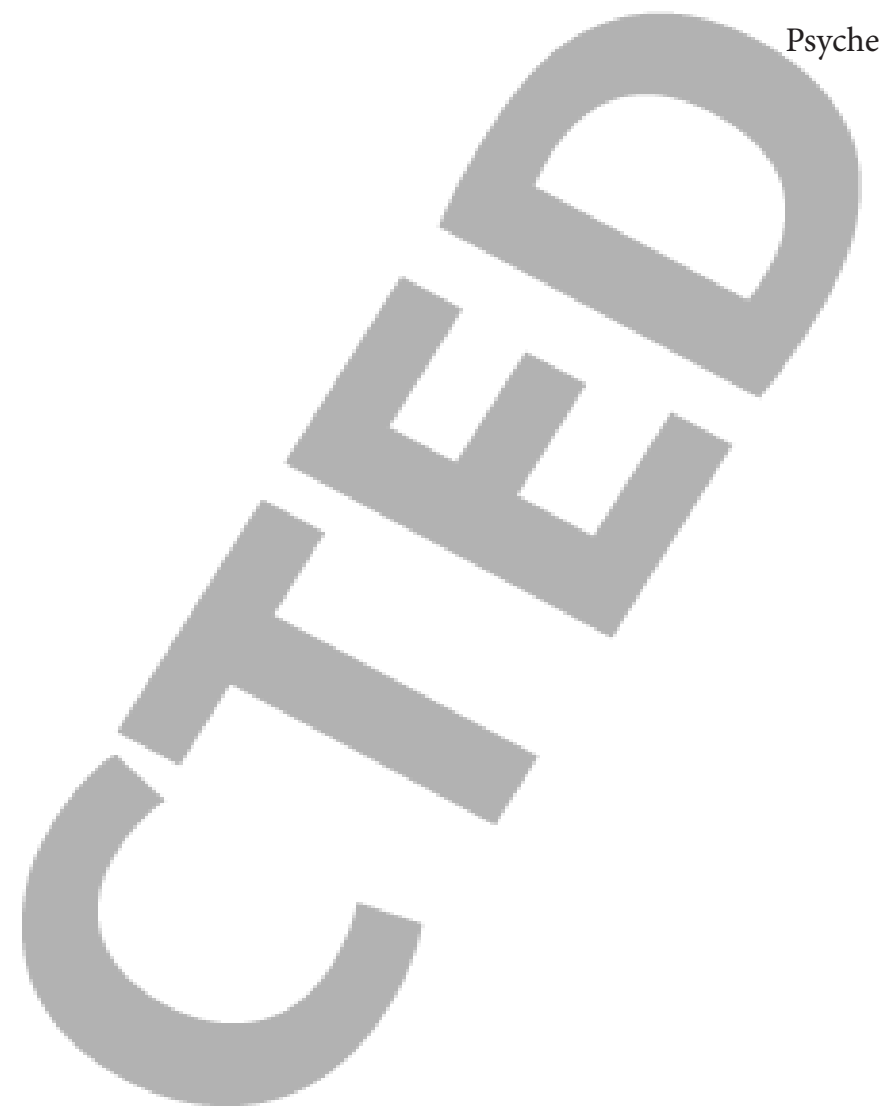

[79] L. A. Garibaldi, I. Steffan-Dewenter, R. Winfree et al., "Wild Pollinators Enhance Fruit Set of Crops Regardless of Honey Bee Abundance," Science. 2013.

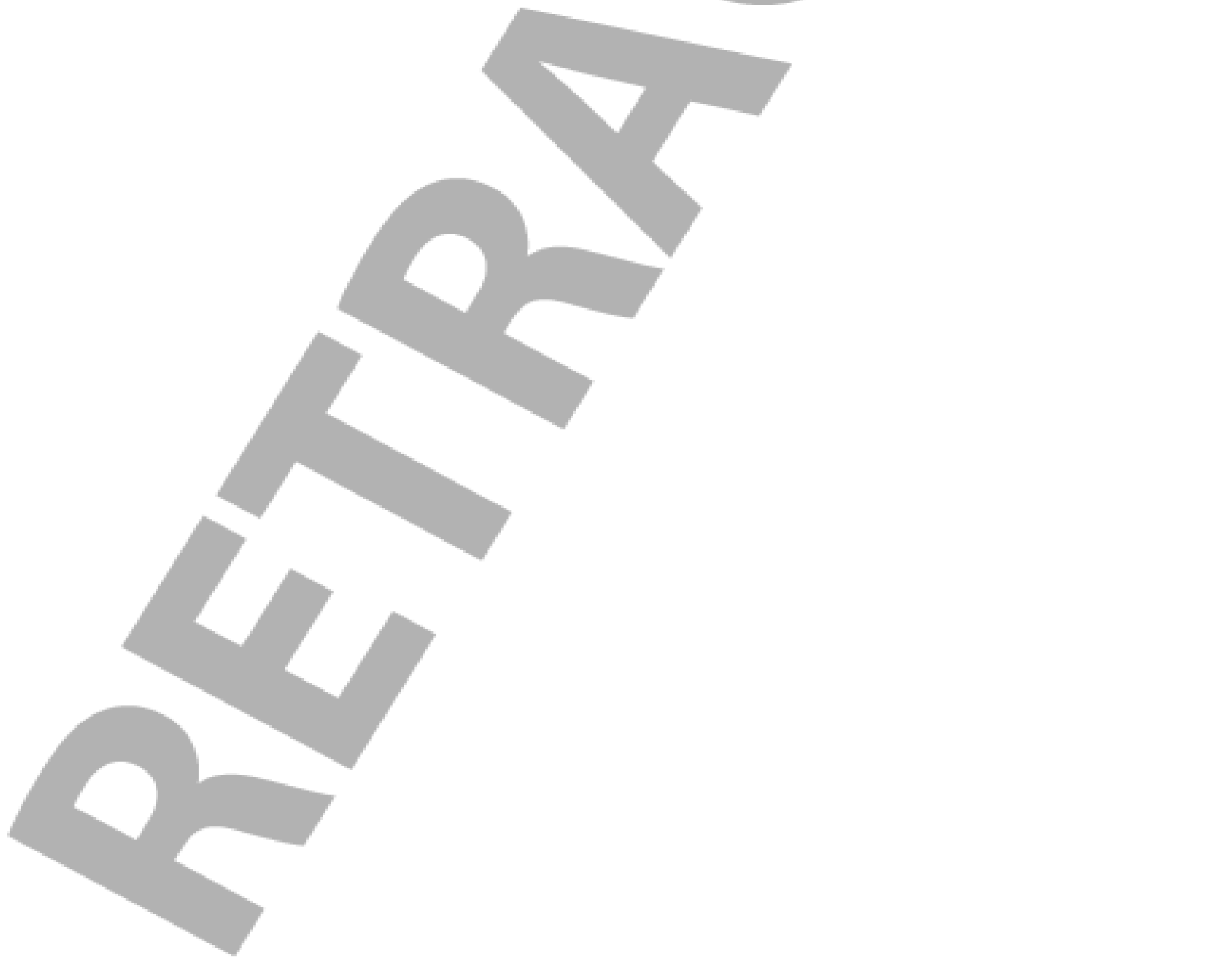

